\title{
Functional treatment of Colles fractures : a prospective clinical study
}

Citation for published version (APA):

de Bruijn, H. P. (1987). Functional treatment of Colles fractures : a prospective clinical study. [Doctoral Thesis, Maastricht University]. Rijksuniversiteit Limburg. https://doi.org/10.26481/dis.19870508hb

Document status and date:

Published: 01/01/1987

DOI:

10.26481/dis.19870508hb

Document Version:

Publisher's PDF, also known as Version of record

\section{Please check the document version of this publication:}

- A submitted manuscript is the version of the article upon submission and before peer-review. There can be important differences between the submitted version and the official published version of record.

People interested in the research are advised to contact the author for the final version of the publication, or visit the DOI to the publisher's website.

- The final author version and the galley proof are versions of the publication after peer review.

- The final published version features the final layout of the paper including the volume, issue and page numbers.

Link to publication

\footnotetext{
General rights rights.

- You may freely distribute the URL identifying the publication in the public portal. please follow below link for the End User Agreement:

www.umlib.nl/taverne-license

Take down policy

If you believe that this document breaches copyright please contact us at:

repository@maastrichtuniversity.nl

providing details and we will investigate your claim.
}

Copyright and moral rights for the publications made accessible in the public portal are retained by the authors and/or other copyright owners and it is a condition of accessing publications that users recognise and abide by the legal requirements associated with these

- Users may download and print one copy of any publication from the public portal for the purpose of private study or research.

- You may not further distribute the material or use it for any profit-making activity or commercial gain

If the publication is distributed under the terms of Article $25 \mathrm{fa}$ of the Dutch Copyright Act, indicated by the "Taverne" license above, 


\title{
Functional treatment of Colles fractures
}

\author{
A prospective clinical study
}

\section{PROEFSCHRIFT}

ter verkrijging van de graad van doctor in de Geneeskunde aan de Rijksuniversiteit Limburg te Maastricht, op gezag van de Rector Magnificus, Prof. Dr. F.I.M. Bonke, volgens het besluit van het College van Dekanen, in het openbaar te verdedigen in de aula van de Universiteit op vrijdag 8 mei 1987, des namiddags om vier uur

door

Hans Peter de Bruijn

Geboren te Haarlem 
Promotor : Prof. Dr. J.M. Greep

Co-promotor : Dr. JW.J.L. Stapert

Referenten : Prof Dr. J. Drukker

Prof. Dr. R.JA. Goris

Prof. Dr. A.J. van der Linden

Prof. Dr. R.K. Marti

Het verschijnen van dit proefschrift werd mede mogelijk gemaakt door de steun van:

Stichting het Scholten-Cordes Fonds

Lameris Instrumenten B.V.

Lohmann Verbandstoffen B.V.

Push-Braces

Smith and Nephew B.V.

West Chirurgische Instrumenten B.V. 
To Xandra,

Rutger and Larissa. 
Zet- en drukwerk: Krips Repro Meppel

ISBN: 87-16-06381-3

ISSN: $0300-8827$

Key words: Colles fracture

Functional treatment

Relation anatomy-function 


\section{CONTENTS}

CHAPTER 1

1.1

1.2

CHAPTER 2

2.1

2.2

2.3

2.4

2.5

CHAPTER 3

3.1

3.2

3.3

3.4

3.5

3.6

3.7

3.8

3.9

3.10

3.11

3.12

3.13
INTRODUCTION

Introduction

Aim of the thesis

\section{THE NORMAL WRIST AND HAND}

Introduction

Motion in the wrist region 3

Function of the hand 3

Radiographic anatomy 4

Conclusion

\section{THE COLLES FRACTURE, REVIEUW OF LITERATURE}

Historical review

Definition

Pathogenesis

Incidence

Clinical examination

Radiographic examination

Fracture classification 10

Management of the injury 11

1 anaesthesia $\quad 12$

2 reduction 12

3 methods of fracture treatment: 12

1 introduction 12

2 immobilisation with plaster casts 13

3 functional treatment 14

4 skeletal fixation 15

4 management of a compartment syndrome 16

5 the post-reduction period 16

6 the rehabilitation period 16

Complications $\quad 17$

1. complications of applied techniques 17

2 redislocation $\quad 17$

3 nerve injuries $\quad 17$

4 tendon injuries $\quad 18$

5 Sudeck dystrophy $\quad 18$

6 malunion 19

7 loss of radio-ulnar integrity 19

8 post-tramatic arthritis 19

9 loss of motion and function 19

10 persistant pain 20

11 Dupuytren contracture 20

Evaluation of end results 20

End results 22

Prognostic factors of the functional end result 24

Conclusion and discussion 24 


\section{CHAPTER 5 METHODS}

5.1

5.2

5.3

5.4

5.5

5.6

5.7

5.8

5.9

5. 10

CHAPTER 6 PATIENT POPULATION
31

31

32

32

39

39

41

43

44

44

47

CHAPTER 7 RESULTS

7.1

7.2

7.3

$7 \cdot 4$

7.5

7.6

Functional recovery 53

Functional end result

Complications

Anatomical end result

56

Relation between anatonical and functional

57

end result

58

CHAPTER 8 DISCUSSION AND CONCLUSIONS

8.1

DIscussion

69

8.2

Conclusions

CHAPTER 9 SUMMARY 


\section{CHAPTER 1}

\section{INTRODUCTION}

\section{I Introduction}

In 1814, the Irish surgeon Abraham Colles published an article about a very common fracture of the distal radius that now bears his name. Slnce this publication, numerous articles have been written concerning this particular fracture. The great number of articles and the great variety of recommended therapies, indicates that until now, no consensus exists on the best treatment of Colles fractures. The high percentage of unsatisfactory end results and the high incidence makes the colles fracture a medical problem.

The history of fracture treatment reveals a continuous search for improvement of the therapy. In the past, fracture treatment consisted of reduction and immobilisation of the injured extrenity with splints or casts, untill osseous union had accurred. Immobilisation was felt to be necessary for bone healing. As a result of this, muscle and bone atrophy, long periods of disability and joint stiffness were often seen.

Some decades ago operative intervention with anatomical reduction and stabile osteosynthesis gained considerable popularity. By early excercises quick functional recovery could be obtained. Important drawbacks to operative intervention were the risks of infection and pseudarthrosis. In recent years, functional fracture treatment was developed. The basis of this functional treatment is to permit and encourage early motion and function in the injured extremity by means of an external. brace. Such a brace merely stabilises the fracture, necessary for reduction of pain and maintenance of alignnent, however it does not immobi1ilse the fracture. Sarmiento (163), propagated this method as an alternative to osteosynthesis where early restoration of function is imperative for an optimal functional result without the drawbacks of surgical intervention. He believes that "motion and excercise is good for tissue healing, rehabilitation and prevention of disability of joints and 1lmbs and that the sacrifice of absolute anatomic reduction of fractures by his method $1 \mathrm{~s}$ a small price to pay for the restoration of function and rapid healing" .

The treatment of the Colles fracture underwent the same evolution. Various different forms of plaster cast immobilisation and many different types of operative interwention have been used. Recently, closed functional treatment was also advocated in the treatment of colles fractures. In 1975, Sarmiento (159) developed a functional brace for Colles fractures which permits early volar flexion and ulnar deviation but prevents dorsal flexion and radial deviation of the wrist and prevents pronation of the forearm. The forearm is kept in fixed supination by extension of the brace above the elbow. Flexion in the elbow is permitted, the last 45 degrees of extension in the elbow is restricted. In this way, early motion and function of the wrist during the healing period is achieved and is encouraged. In retrospective studies, Sarmiento claimed with his method a good anatomical and functional end result and an early functional recovery $(159,162)$. 
In the Universtry Hospital Mastricht, The Netherlands, it was noticed that a constaerable number of patients kept loss of function and pain after a Colles fracture. The usual treatment consisted af reduction and immobilisation in a conventional dorsal lower arm plaster of paris splint for four weks followed by excercises. Functional treatment of Colles fractures seemed to be a promising method in order to achieve better results.

1. 2 Alm of the thes $1 \mathrm{~s}$

The aim of this thesis is to investigate in a prospective clinical study whether functional treatment of colles fractures indeed leads to better results than conventional plaster treatment in order to establish the application fleld of functional treatment for this kind of fracture.

In the following two chapters, a rewiew of literature is given with the purpose of searching for methods to evaluate possible differences between methods of treatrent, to standardize the management of the injury, and to reveal the state of art of the management of the colles fracture necessary for the design of the study. 


\section{THE NORMAL WRIST AND HAND}

\subsection{Introduction}

In this chapter a review of literature is restricted to those aspects of the normal wrist and hand that apply to a study on the therapy of colles fractures. No general description of anatony of the wrist region as found in standard anatomy textbooks is given as it is not the aim of this thesis to contribute to this subject.

\subsection{Motion in the wrist region}

The wrist can angulate in any direction and by a combination can circumduct. It has a most complex articular configuration which does not lend itself readily to simple mechanical description and interpretation (54). The wrist joint functions with 3 parallel longitudinal chains. In each of these chains the proximal carpal functions as an intercalated bone (97). The specific shape of these intercalated bones establishes a simultaneous movenent in the radio-carpal and the mid-carpal joints which makes dorsal flexion, volar flexion, ulnar deviation, radial deviation or combinations possible. The centre of rotation in the dorsal-volar flexion and ulnar-radial deviation plane is located in the head of the capitate bone $(6,127,189,201)$. The reported mean values of maximal excursion of motion in the wrist are as follows $(3,28,86,134,189)$ :
dorsal flexion
volar flexion
$50^{\circ}-80^{\circ}$
$60^{\circ}-85^{\circ}$
ulnar deviation
radial deviation
$30^{\circ}-46^{\circ}$
$15^{\circ}-29^{\circ}$

The American Academy of Orthopaedic Surgeons (3) advises recording wrist motion with a goniometer with the forearm in pronation. The measurements should be based on the principal of the neutral zero method (The neutral position is the zero starting position).

In the forearm pronation and supination takes place, involying the proximal and distal radio-ulnar joints. The mean values of the maxtmal excursion of pronation and supination are $(3,86)$ :
pronation
$80^{\circ}-90^{\circ}$
suplnation
$80^{\circ}-90^{\circ}$

According to the Anerican Academy of Orthopaedic Surgeons (3) pronation and supination should be measured with the elbow at right-angle flexton, thus blocking rotary motions of the humerus.

\subsection{Function of the hand}

Impaired wrist function due to a colles fracture may alter hand function as the wrist is the key joint for proper function of the hand $(128,184)$. Several fundamental motor functions of the hand can be distingulshed $(25,96)$ :

- Opening of the hand consisting of finger extension and of abduction of the thumb.

- Closing of the hand, consisting of finger flexton and adduction and consisting of flexton, adduction and opposition of the thumb. 
- Grip; several types can be distingulshed (89): power grip as when grasping a cylinder

ball grip as when grasping a ball

pinct grip as when pleking up tiny objects

three polit grip as wen holding a pen

key grip as when opening a door with a key.

\subsection{Radiographic anatony}

Three types of radiographic measurements are commonly used in anatomical evaluation of the distal radius. The measurements are recorded against the longltudinal axis of the radius. In A.P. and lateral vieuws the longltudinal axis is defined as a line through two points located in the middle of the diaphysis of the radius at distances of $3 \mathrm{~cm}$ and $6 \mathrm{~cm}$ proximal to the radio-carpal joint (71) (Figure 2.1).

Figure. 2.1 Radiographic measurements

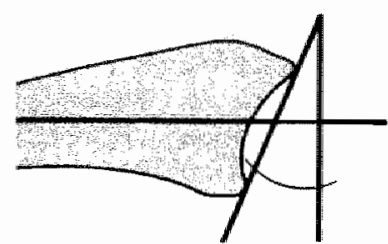

wolar angle

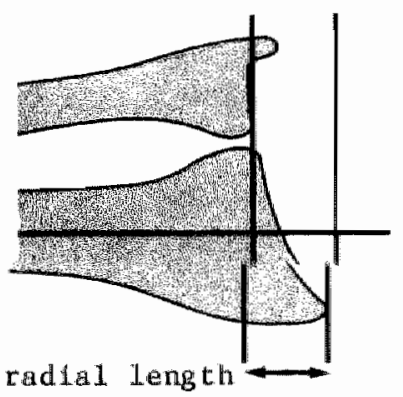

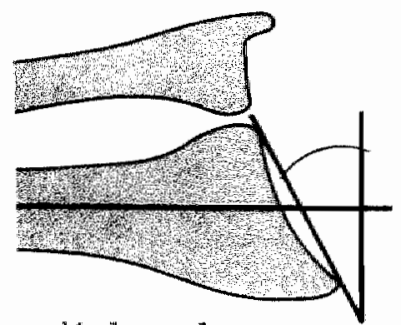

radial angle

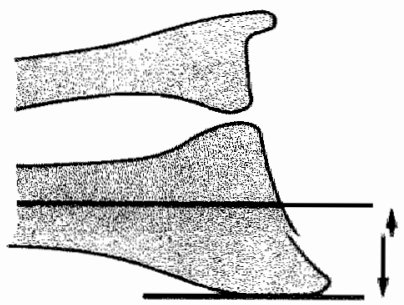

radial width

The volar angle measured on lateral vieuws is defined as the angle between a line jolning the volar and dorsal marglns of the distal radial surface and a line perpendicular to the longitudinal axis of the radius $(73,109)$. The volar angle averages $11^{\circ}-12^{\circ}$, rangling from $0^{\circ}-21^{\circ}$, with a standard deviation of $4.3(71,74)$.

The radiall angle measured on A.P. vleuws is the angle between a line joining the tip of the radial styloid and ulnar corner of the distal radial surface and a line perpendicular to the longitudinal axis of the radius. The average radial angle is $23^{\circ}$ with a range of $13^{\circ}-30^{\circ}$ and a standard deviation of $2.2(71,74,86,164)$.

The radial length measured on A.P. vieuws is the distance between two perpendiculars to the longitudinal axis of the radius, one drawn through 
the tip of the radial styloid process and the other tangential to the distal articular surface of the ulna. The radial length awarages 12 mon with a range of $8-18 \mathrm{~mm}$ and a standard deviation of $2.3(71,86,164)$.

A fourth type of measurement seems to have practical implications for the Colles fracture (Paragraph 3.6). The radial width measured on A.P. vieuws is the distance between the longitudinal axis and the most lateral point of the radial styloid (Figure 2.1).

2.5 Conclusion

parameters for external evaluation of motion in the wrist region and motor function of the hand, and for anatomical evaluation of the distal radius, as far as necessary for this study, are well described in literam ture. 



\section{CHAPTER 3}

\section{THE COLLES FRACTURE, REVIEUW OF LITERATURE}

\subsection{Historical Review}

The first description of the colles fracture was probably glven by Claude pouteau in 1783 (145). He was the first to differentiate the fracture of the lower distal radius from wrist dislocations. In 1814 , in the Edinburgh Medical and Surgical Journal the Irish surgeon Abraham Colles (38) published an article "On the fracture of the carpal extremity of the radius." In this paper he described the dorsally displaced radius fracture, occurring in the distal one and a half inch, that now bears his name. His method of treatment consisted of traction to reduce the displaced fracture and application of volar and dorsal tin splints. With great self-assurance, he remarked "The cases treated on this plan have al1 recovered without the sillilest defect on deformity of the limb, in the ordinary time for the cure of fractures". In poorly treated fractures, he stated "One consolation only remains, that the limb wil at some remote period again enjoy perfect freedom in all its motion and be completely exempt from pain: the deformity, however, will remaln undiminished through 1 ife".

\subsection{Definition}

The colles fracture is regarded as a complete transverse fracture of the distal $3 \mathrm{~cm}$ of the radius in adults with dorsal angulation, dorsal displacement, radial angulation and radial displacement, often with a supination displacement and frequently with impaction of the distal fragment $(9,34,55,86,131,142,144,192)$. Some authors also regard a non-displaced transverse fracture of the distal radius to be a colles fracture $(8,163)$.

\section{3 Pathogenesis}

The Colles fracture occurs most often after a fall on the outstretched hand with the wrist in dorsal flexion $(9,23,73)$. The distal end of the radius forms the entle bony articulation between the forearm and the hand and is thus subject to the major forces in a fall on the outstretched hand ( 41$)$. The majority of the energy however, is absorbed by the soft tissues and jolnts of the hand (137). The transition zone between the dense cortex of the shaft and the cancellous distal part surrounded by only a thin layer of cortical bone is a point of least resistance and therefore often the site of the fracture $(41,42,183)$. The amount of energy to produce a colles fracture decreases with age (2).

Cadaver experiments showed that fractures of the distal radius are produced when the dorsal flexion of the wrist varies from 40 to 90 degrees $(73,111)$. The type of fracture depends on the position of the wrist and the direction and magnitude of the violence $(9,23,73)$. In Colles fractures, the usually sharp, not comminuted fracture on the volar side contrasts with the cominuted fragments on the dorsal and radial side. This suggests that the volar surface of the radius may first fracture by dis- 
traction with the fracture propagating and conpacting cancellous bone on the dorsal and radial side which then becomes cominuted (54). This conminution of the cortex invites dorsal and radial angulation of the distal fragments $(34,55)$. The periostem on the volar side ruptures. The perfosteum and the flbrous part of the tendon sheaths on the dorsal surface ag we 11 as the ligaments on the wist remain essentially intact $(41,42,50)$.

Both the distal radio-ulnar jolnt as well as the radio-carpal joint may be involved in the fracture (73). Subluxation of the radio-ulnar joint will occur only with lesions af the triangular fibrocartilage, attached to the unar styloid and the medio-dorsal part of the distal radius. There can be a rupture of the fibrocartilage or an avulsion of one of $1 \mathrm{tg}$ insertions (74). Weigl and Spira (195) demomstrated by arthrography that the triangular fibrocartilage shows either perforation or detachment in about 60 percent of the colles fractures. However, autopsy showed perforation in 41 percent of normal wrists. Avulsion of the ulnar stylotd process accompanies colles fractures in 50 to 60 percent of the cases $(9,31,55,71,109,183)$.

\subsection{Incidence}

The Colles fracture is one of the most frequent fractures in man; only fractures of fingers and ribs are more frequent $(42,58)$. It accounts for 8-15\% of all bone injuries $(76,86,183)$. Alfram and Bauer (2) found an incldence of $0.17 \%$ a year 1 n the population of a big city in Sweden. The mean age is between 48 and 50 years for women and 45 years for man $(9,30)$. Before the age of forty, the incidence of colles fractures is about equal in males and females. In men, the incidence rises but slightly from forty to eighty years of age, whereas in women the incidence rises 8-10 times fron forty to sixty after which it remains constant $(2,63,135)$. The overall male to fenale ratio is about 1 to 5 $(73,109)$. This difference correlates with an increased incidence of osteoporosis after the menopause in woman $(12,135,147)$.

\subsection{Clinical exanination}

The clinical appearance in a markedly displaced colles fracture is that of the classical dinner fork and bayonet defornity; the carpus and hand are displaced in respectively a dorsal and radial direction. The ulnar side migt show a volar prominence of the distal ulna $(40,55)$. The hand is held in pronation and is somewhat flexed. Supination is impossible. Active movement of hand and fingers is either markedly or completely 1imlted (42). A fracture with displacement ustally produces a large extravasation of blood and great swelling which begins quickly and may involve the hand, fingers and entire forearm (41).

\subsection{Radiographic exanination}

Radiographic studies in both anterior-posterior and lateral projection are required to confirm the diagnosis, to determine the type of fracture and to assess the degree of displacement $(21,73,109)$. The colles fracture must be distinguished from other fractures of the distal radius, like the Silth"s fracture with volar displacement of the distal fragment, the dorsal Barton fracture (dorsal margin fracture), the volar Barton (volar margin fracture) and the chauffeurs fracture (isolated radial styloid fracture) as these require a different treatment (Figure $3.1)(11,13,32,55,67,86)$. The colles fracture however, represents we11 
Figure 3.1 Different types of distal radius fractures
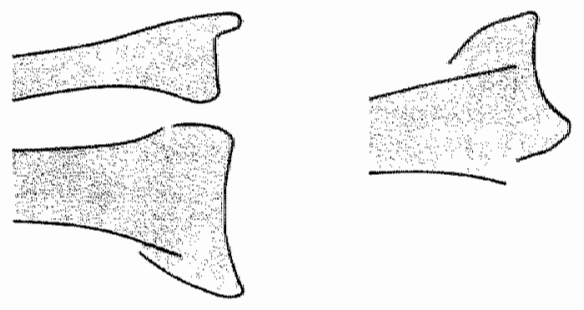

colles
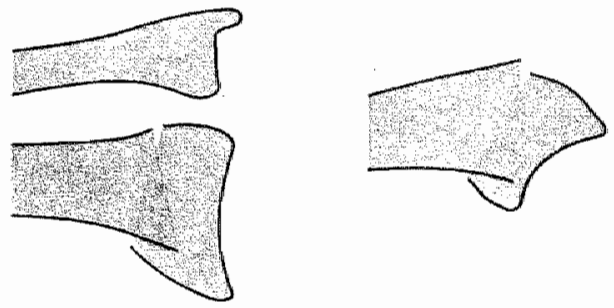

Snith's
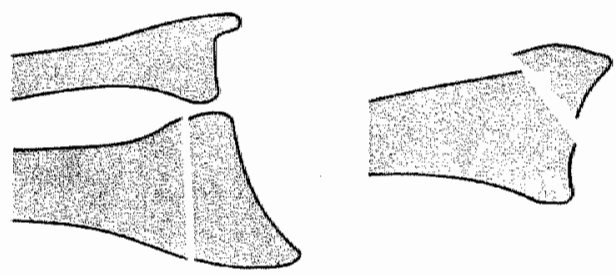

Dorsal Barton
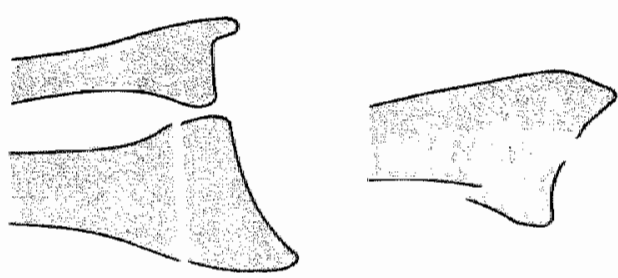

Volar Barton
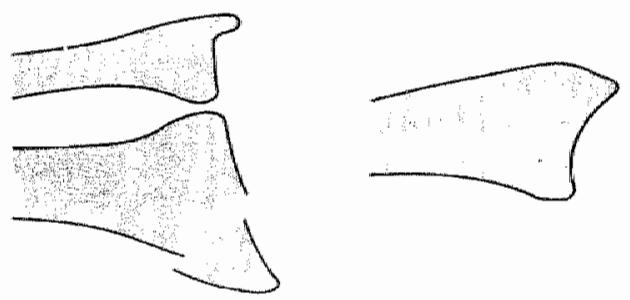

Chauffeurs 
over 90 pexcent of all distal radial fractures (86). Accompanying fractures or dislocations, lri the same extremity are rare $(9,15,132)$. Subluxation of the distal radiominar joint may be apparent on the lateral projection, particularly if the superimposed triquetral shadow no longer lies in line wath the distal ulna (55). Volar angle, radial angle and radial length can be measured to decermine the degree of displacement and impaction. Van der lilnden and Exicson (112) added the so-called radial shift, defined as the difference in radial width between the injured and uninjured side (Figure 3.2 ). In their opinion the radial shift combined wh the volar angle displacenent (volar angle difference between the injured and uninjured wrist) provides enough information about the displacement as the two criteria are independent of each other.

Eigure 3.2 Radial shift

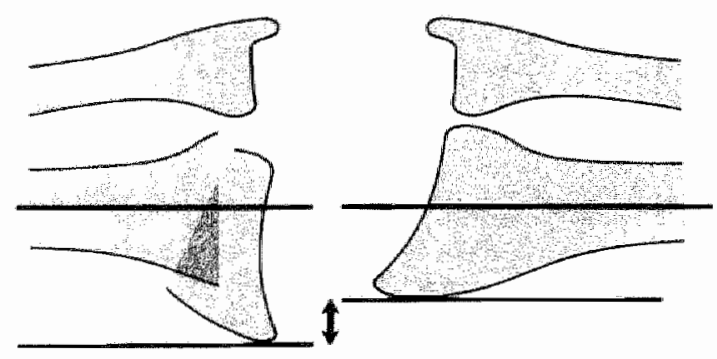

\subsection{Fracture classiflcation}

Many different classifications of the colles fracture have been developed, depending on the direction of displacement (51), the presence of injury to the triangular fibrocartilage $(126,187)$, the localisation of fracture lines (150), the degree of comminution $(110,139)$, combinations of joint involvement and degree of displacement $(74,76,109,163)$ or combinations of joint involvement and ulnar styloid fracture (73). In one classification systen no less than 34 different types were distinguished (59). At present the systems of Frylaman (73) and Sarmiento (163) have galned recognition $(35,43,50,55,172)$.

Frykanan olassffication is most frequently used. It is based on the involvement of the radio-carpal joint, radio-ulnar joint and ulnar stylaid and consists of a scale of 8 different types with an increasingly unfavourable prognosis (Figure 3.3 ) (73).

Sarmiento classified Colles fractures into 4 types, depending on displacement and involvenent of the radio-carpal joint (Figure 3.4) (163). Type 1 non-displaced fractures without radio-carpal joint involvement Type 2 displaced fractures wi thout radio-carpal joint involvement Type 3 non-displaced fractures with radio-carpal joint involvement Type 4 displaced fractures with radio-carpal joint involvement According to Samiento (163) this classification is based on anatomic, therapeutic and prognostic considerations. Type 1 and 3 are regarded as stable fractures. Type 2, if properly reduced, might be stable, however, redisplacement might occur. Type 4 is supposed to be the most difficult and unstable fracture. 
Higure 3.3 Frykan's fracture classification

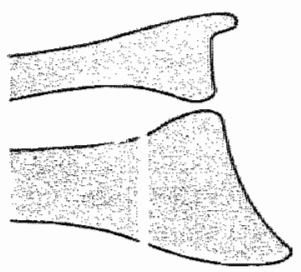

Type 1

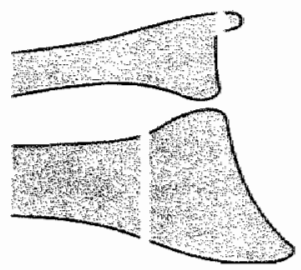

Type 2

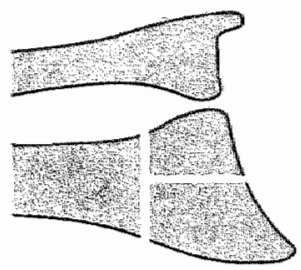

Type 3

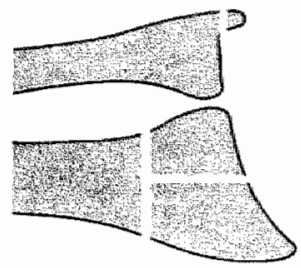

Type 4

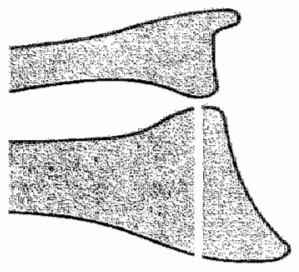

Type 5

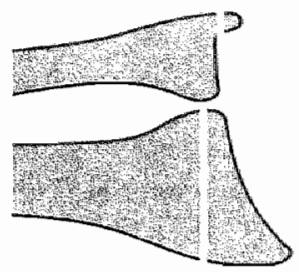

Type 6

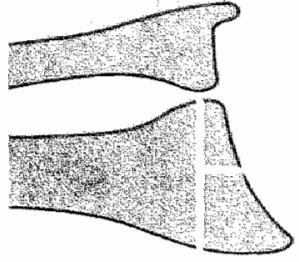

Type 7

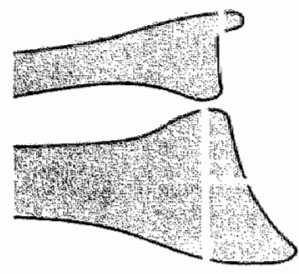

Type 8 ,

Figure 3.4 Sarmiento's fracture classification

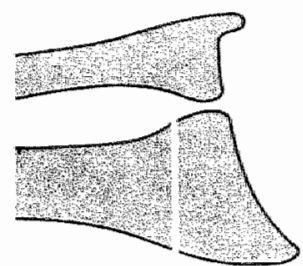

Type 1
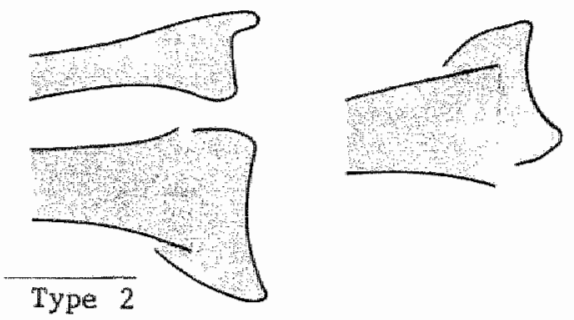

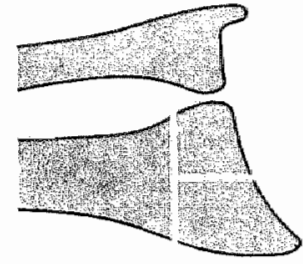

Type 3

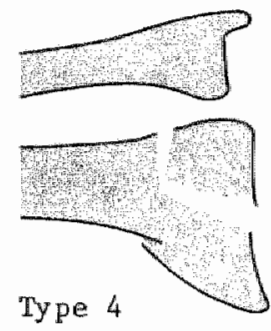

3.8 Management of the injury

The colles fracture should be regarded as an injury of the wrist reglon accompanied by a colles type fracture of the distal radius. The injury is not only limited to the bone. The damage to the soft tissues should also be taken into consideration (177). Not only the treatment of the fracture in a restricted sense (technique of immobilisation or stabilisation) but also anaesthesia, method of reduction, post-reduction care, rehabilitation and prevention or treatment of complications are part of the management of the injury $(109,177)$. 
3.8.1. Anaesthesia

Several form of anaesthesia for the reduction in displaced fractures exist. Local infiltration of $10-20$ wil of lidocaine, 1 or $2 \%$ into the fracture haenatona is commonly used $(21,62,73,109,110)$. Additional infiltration of the ulnar side night be usefull $(17,130)$. Dinley and Michelinalus $(53)$ found local anaesthesia very effective and whout adverse effects or infection in 280 patients. General anaesthesia has the advantage of muscle relaxation $(36,76,83)$ but its use is limited because patients cannot be treated on an out patient-basis (73). Bultitude et al (25) in a prospective study prefered $i . v$. diazepam alone to general anaesthesta. Regional intravenous anaesthesia (Biers anaesthesia) and axillary plexus block anaesthesia have also been described as safe procedures $(36,84,85,146)$.

\subsubsection{Reduction}

Reduction th displaced fractures should be done as soon as possible (109, 144) although Frykman (73) found no significant difference between immediate and 24 hours delayed reduction. Satisfactory reduction can almost al ways be secured by closed methods (46). Two methods are commonly used:

1. According to harniley (34) impaction should be freed by hyperextension, tmediately followed by volar flexion and pronation to "lock" the fragments ( 110$)$. The usually intact periosteum and fibrous parts of the tendon sheath on the dorsal surface forms a soft tissue "hinge" which must be kept under tension to maintain the reduction (46). However, hyperextension inght add unnecessary additional injury to the soft tissues $(29,30)$.

2. Böhler (20) described a method of traction for 2-5 minutes to disimpact the fragments. Additional manual pressure is applied on the distal fragments to obtain reduction. This method is frequently used $(13,17,23$, $36,71)$. The traction can either be applied manual1y (21) or by the use of gravity. For the latter finger trap traction is used for about 15 minutes with so called "Chinese finger traps", while countertraction is achleved by a sling over the humerus suspended on a weight of $3-10 \mathrm{~kg}$ with the elbow flexed to 90 degrees $(13,24,36,50,56,159,182)$.

In the 1fterature, no indication was found for the amount of displacement necessary to reduce the fracture or how much displacement can be accepted without the necessity for reduction.

\subsubsection{Methods of fracture treatment}

3.8.3.1 Introduction

Many different methods of immobilisation or stabilisation have been described. The indication for these different methods is the most controversial detall in the management of colles fractures (109). This suggests that no method is completely satisfactory. The method chosen by the authors refect their opinion on the relation between the anatomical and functional end result. To those who assume a close causal relationship, the aim of the treatment is to produce an anatomical reduction and maintain this position till consolidation $(5,9,10,17,26,30,31,35,36,37$, $42,43,67,76,79,86,92,108,109,120,126,131,169,182,196)$. Others pointed out that even a significant collapse of the fracture fragments does not preclude a good functional and result $(30,56,139,159,175)$. To some a good functional end result depends mainly on early exercises and fast consolidation $(34,163)$. According to Charnley (34) a controlled collapse of the cancellous bone is the treatment of choice as this leads to quick 
periosteal union which is the best wey to functional recovery. Hudson and Rusnack (88) and Spira and Weig1 (175) believed that comminuted fractures of the distal radius can heal only by shortening of the radius. They perfomed no reduction at all, but treated cominuted Eractures with primary resection of the distal ulna.

The different methods of treatment can be categorised in:

A. conservative treatment by: - imobilisation with plaster casts

- stabilisation with functional braces

B. operative treatment by : - skeletal fixation.

operative treatment is mainly indicated for unstable fractures: stable fractures usually are treated conserwatively. Cominuted fractures usual$1 y$ are regarded as unstable $(36,43,50,56,83,92,163)$. Cooney et a 1 (43) diagnosed instability in the presence of much cominution, severe dorsal angulation (20 degrees or more) or extensive intra-articular involvement. Redislocation is proof of instability to others $(69,86)$. Minimally displaced or non-displaced fractures are treated conservatively as these are generaly considered to be stabile $(42,72,86,148,163)$.

\subsubsection{Inmobilisation with plaster casts}

Nunerous techniques af plaster cast or splint imobilisation have been developed. The plaster should never extend beyond the metacarpophalangeal joints and should pemit full finger motion $(8,17,19,21,62,68,72,74$, $76,86,110,120,150,170,192)$. Most frequent $1 y$ a below-the-elbow plaster cast or splint is used $(17,19,21,34,68,71,73,109,110,120,150,170,173)$.

\section{- Position of the wrist:}

A position of the wrist between volar and dorsal flexion, combined with moderate ulnar deviation according to Bobler (12) is often used $(73,109$, $124,182)$. A position in moderate volar flexion and moderate to full ulnar deviation according to Charnley (34) is also common $(17,67,68,72,74$, $76,110,120,150,170,192)$. The Cotton-Loder position of forced full palmar flexion, ulnar deviation and pronation (45) is abolished nowadays because of its association with median nerve compression $(75,86,117)$. Soren (173) placed the wrist in neutral position and made indentations on the radial and dorsal side of the plaster to prevent displacement. Stewart et al (180) concluded that the position of splintage does not influence the anatomical end result to a noteworthy degree.

\section{- Position of the forearm:}

A below-the-elbow plaster results in a neutral position of the forearm as pronation and supination are not fully restricted $(17,21)$. Some authors proposed a supination position of the forearm wth the help of an above-the-elbow plaster $(12,55,62,113)$. Samiento et a 1 (158) advoca ted this position as BMG studies showed reduced muscle activity of the brachioradialis muscle in supinated forearins. They clatmed that this muscle, being attached to distal end of the radius, plays an important role as a defoming force, causing redislocation in colles fractures. others prefered an above-the-elbow plaster with the forearm in pronation $(42,60,76,127)$. Wahlström (190) concluded in a prospective randomised study that contraction of the pronator quadratus muscle, attached to the distal radius, could cause redislocation resembling the or 1 ginal deformity. This muscle contracts mainly when the forearm is in supination, which makes the pronation position more suitable. Both Hinding (87) and 
Fool (144) found 1r prospective studies that an above-the-elbow plaster cast has no avantages over a below-the-lbow plaster.

- Change of plaster:

often the plaster is left unchanged for the whole linmobilisation period. It can be adfusted by ne bandage after oedema has subsided (55) or night be completed to a circular plaster after some days $(19,120)$. Sometumes the plater 1 changed for a complete new one $(72,74,170)$. A complete clrcular plaster from the beginning is seldomly used $(124,173)$.

\section{- Casting material:}

Majnly plaster of Paris $i s$ used. Nev casting material like Isoprene (Orthoplast) or polyurethane may have the advantage over plaster of parls of belng 1 ghtter and water repellent. However, no difference in results was found with the use of different materials $(151,160)$.

\subsubsection{3 functiona 1 treatment}

Samiento et al $(159,162,163)$ developed the conservative method of functional bracing of colles fractures. By use of an external brace early motion and Eunction is made possible, without operative fixation of fracture fragments. The brace stabilises the fracture, which is necessary for reduction of paln, mantenance of alignment and prevention of deformity, it does not immobillse the fracture fragments. This approach is based on the bellef that inmobilisation of the fragments and the joints above and bellow the fracture is not necessary for fracture healing (107). It is also based on the finding that the soft tissues of the injured extrenity play a major role in providing the stability necessary for uninterrupted osteogenesis. Sarmiento and latta (163) suggested that early motion at the fracture site enhances osteogenesis. To support this theory, they remarked on the rapid healing under constant motion of fractures of cla$v$ lcles and ribs. They demonstrated in laboratory induced fractures that early function leads to early vascular invasion (107). The increased ingrowth of capillaries stimulated by muscle activity is accompanied by osteoblastic and osteoclastic activity. As early revascularisation comes from the surrounding tissues, osseous callus forms first in the periphery, fomling an osseous cap over the fibrous callus and haematoma. Garly function thus leads to early periosteal callus which is mechanically strong. This process is the quickest way to restore the strength of the fractured bone $(107,129,161)$. Without movement of fracture fragments on the other hand periosteal callus is minimal (4). Here endosteal and end-tomd bridgling callus predominates with less strength of the callus (129). Consequently, Sarmiento (163) stated that "rigld internal Exation of fracture fragments or complete immoblisation of the injured extrentty violates the normal biological processes and changes the manner $1 \mathrm{n}$ which the fracture repairs itself. In this case fractures heal not because they are fixed or immobilised, but in spite of it. The early motton and function leads to a faster and better functional recovery, preventing stiffness and disability which is often encountered with immoblisation methods of treatment. Functional treatnent approximates the natural reparative processes and the rehabilisation schemes which the body provides through pain as normal biological feedback mechanism." According to Samiento and Latta (163) undue attention has been paid to the importance of anatomical reduction of the fragments and maintenarce of that position during healing, since the introduction of radiology in the assessment of fractures. 
Samienta's functional bracing of colles fractures consists of two phases. In the first week the fractured arm is immobiliged in an above-theelbow plaster splint with the elbow in flexion, the forearm in suplmation and the wrist in moderate ulnar and volar flexion. After that the splint is changed for an Isoprene brace that permits motion of the elbow till the last 45 degrees of extension and permits volar flexion of the wrist. It prevents pronation of the foreara and radial deviation and dorsal flexion of the wrist. The position of the forearm remains in supination. Although Samiento described that only early volar flexion with this brace is pernitted, from the shape of the brace it can be concluded that early ulnar devlation is also possible. Samiento et al (162) found in a prospective study that displaced fractures functionally treated in supination showed less redislocation than displaced fractures functionally treated in pronation. No difference between pronation and supination position was seen in undisplaced fractures.

Recently Samiento's functional bracing of colles fractures also has been used by others $(16,26,33,178)$. Stewart et al (178) described in 1984 an even more functional bracing method with a below-the-elbow brace that anly prevents dorsal flexion of the wrist. Pronation and suplnation are not fully restricted.

\subsubsection{Skeletal fixation}

The advocates of skeletal fixation all assume a clase causal relationship between the anatomical end result and functional end result. Skeletal fixation is mainly used for unstable and commuted fractures.

Various methods of operative fixation are recommended. Bohler (22) developed a method of self-contained traction, by incorporating Kirschner wires or pins in plaster. Many variations on this technique have been proposed by placing the wires or pins in different places $(24,36,46,79$, $83,79,83,121,164)$. De Palma (50) described a method of ulnar pinning, fixing the reduced distal radius to the ulna. In another method, wires were drilled through the radial styloid $(10,13,39,40,108)$. Kapanji (94) used intra focal nailing to fix the fragments. Rush and Rush $(154,159$, recomended internal fixation of the radus by an intramedullary pin. In the Roger Anderson technique (5) an external bar links percutaneous plns inserted into the second and third metacarpal bones and the distal radius $(12,43,44)$. The Hoffman external fixation (18), the Hof fom min extemal fixation (98), the sma11 A. 0.-external device (91), the Wagner distraction-compression device (122) and other extermal fixation devices $(43,167)$ have all been recomended in the treatment of comminuted colles fractures. Forgon (69) applied a mint-external fitwation, fixing the distal fragment to the metaphyseal part of the radius to prevent immobilisation of the wrist joint. Internal flution of colles fractures is seldomly used (105). To Marti and Polomski (122) absolute indications for open internal fixation and cancellous bone graft are the commutive impression fractures in which the soft tissue hinge has no function in closed reduction. Intramedullary methylmethacrylate has also been described as a thethod of skeletal fixation (104).

No publications on prospective comparative clinical trials could be found concerning skeletal fixation methods in Colles fractures. 
3.8.4 Management of a comparthent syndrome

The managenent of a compartment syndrome is mentioned separately as its occurrence demands a departure from the usual management. Zimmerman (202) regarded Colles fractures in young patients to be high energy injurles wh a subsequent risk of a compartnent syndrome in the forearm. He advised volar fasclotony and decompression of the carpal tunnel in this type of injury or in signs of 1 schamia. After decompression and reduction skeletal flxation 1 applied. Only one case report was found on pressure recording 1 in a compertment syndrome related to a colles fracture $(25)$.

\subsubsection{The post-reduction period}

The post-reduction period 1 s the period between the application and the removal of the plastex, brace or flxation device. The patient should be instructed on the different side effects of the injury and mangement $11 k e$ welling, numbness and discoloration of the fingers (68). The use of a sling to prevent swelling is recommended for 1 to 4 days $(17,68,72$, 150). Fingex, elbow and shoulder exercise from the beginning, are of great importance $(5,8,9,42,47,62,68,72,83)$.

In conservative treatment, the recomended immobilisation or stabilisation time is rellatively short; 3 weeks $(142), 4$ weeks $(17,62,72,76,124$, $170), 5$ weeks $(21,58,73,109,150)$ or 6 weeks $(13,74,80,111,120,163,173$, $192)$ are mentioned. Wahlstrom et al (191) demonstrated by bone scanning that unstable fractures are healed and stable after 28 days and do not need longer immobilisation. For minimally and non-displaced fractures, 3 to 4 weeks immobllisation is advised $(42,72,86,148)$.

Skeletal fixation requires a longer inmoblisation period because of the slow union of the distracted fragments. The recommended immobilisation period ranges from $6-8$ weeks $(24,36,77,83,121)$ and $8-10$ weeks $(56,79$, 164) up to 12 weeks (5).

\subsubsection{The rehabilitation period}

The rehabilitation period extends from the removal of the plaster, brace of fixation device until full recovery of function. Functional exercises should start mmediately. Active functional exercises should be done by the patient hinself, under proper medical supervision $(73,86)$. Fhysical therapy is indicated for patients with poor motivation and when appropriate functional progress 1 s absent $(67,86)$. The average time off work ater a colles fracture is 2 to 3 months $(31,164,172)$. A period of 4 months can be regarded as a reasonable time before full activity can be resumed (86). However, the final degree of recovery cannot be judged with certainty until a year after the injury $(68,76)$. The grip strength of the hand seens valuable parameter to assess the rehabllitation as 1t gives a good indication of the extrenities ability to function (141). In a review of 156 Colles fractures, Sarmiento et al (162) concluded that early function $v$ a functional bracing in supination leads to eacly recovery of range of motion and rehabilitation, although they never compared this with other methods of treatment. Both Btinger et al (26) in 1984 and Stewat et al (178) in 1984 did not found any difference in speed of recovery between functional bracing and below-the-elbow plaster inmobilisation. 


\subsection{Complications}

Complications in colles fractures are important causes for unsatistactory functional end results (73). Cooney et al (44) found $31 \%$ serlous complications in 564 Colles fractures. The following ala groups of complications can be distingulshed:
1. Complications of applied techniques
2. Redislocation
3. Nerve injuries
4. Tendon injuries
5. Sudeck dystrophy
7. Loss of radio-ulnarintegrity
8. Post-traumatic arthritis
9. Loss of motion and function
10. Persistent pain
11. Dupuytren contracture

6. Malunion

\subsubsection{Complications of applied techniques}

Plaster casts or splints may cause pressure sores (44). If a plaster is too tight, oedema of the hand will develop. In long lasting oedema fibrine exudate induces fibrosis $(80,82,103)$. Skeletal fixation may cause osteitis, pin tract infection, ulceration, pin breakage, neuropathy and stiff wists. Green (79) experienced pin tract drainage in one third of his patients treated with pins in plaster technique. Marsh and Teal (121) found with the same technique in $8 \%$ paraesthesia and in $8 \%$ pin tract infection. With the use of the Roger Andersen external pin fixation Cooney et al (43) reported in $12 \%$ pin loosening.

\subsubsection{Redislocation}

No comonly accepted definition of redislocation was found. The indication for rereduction is not uniform; redislocation more than $10-15^{\circ}$ dorsal angulation, $4 \mathrm{~mm}$ radial length shift or $10^{\circ}$ or radial angle shift have been mentioned $(17,37)$. Collert and Isacson (37) advised rereduction after 2 weeks because the fracture is then "sticky" and will not redislocate again. Cooney et al (44) reported a successfull rereduction in $92 \%$. The recommended treatment after reduction varies from a new plaster to external fixation $(44,92)$.

\subsubsection{Nerve injuries}

Nerve injuries associated with colles fractures are usually reported in $0.2 \%$ to $5 \%$ of the cases $(31,73,86,117,180)$. Mostly these concern the median nerve in its course through the carpal tunnel. Stewart at al (1.79) found a carpal tunnel syndrome in $17 \%$ three months after the fracture. Early median neuropathy is associated with reduction, direct nerve damage at the time of the injury, haematoma, swelling or the CotconLoder position of immobilisation $(44,86,117,149)$. Gelberman et a1 (75) however, found no correlation between the amount of swelling and the carpal canal interstitlal pressures. An acute carpal tunnel syndrome should undergo imediate operatiwe decompression $(44,75,192)$. Transient median nerve symptoms are common and usually caused by haemorrhage and swe1ling. Expectant treatment results in complete cure in most of the cases $(119,176)$. Delayed median nerve injury that usually occurs after 6 weeks is caused by excessive callus formation, degenerative diseases, displaced bone fragments or malunion $(44,86,101,133,149)$. Stewart et al (179) found no correlation between nerve compression and initial displacement; the final volar angle shift however seemed associated with the delayed carpal tunnel syndrome. Operative decompression is indicated if pain and loss of sensation are severe $(31,43,176,180)$. Only a few authors $(117,180)$ used electromyographic studies in stabilising the diagmosis and making an indication for surgery. 
Unar nerve compression is rare $(31,73,155,168,203)$. Paraesthesia of the radial nerve is uncomion and usually clears up spontaneously within a few week (41).

\subsubsection{Tendon Injuries}

Spontaneous rupture of the extensor pollicis longus tendon is reported from 0.4 t11 $1 \%(31,44,48,73,165)$. It occurs usually 6 to 12 weeks after the tratma and is mostly seen after undisplaced or minimally displaced fractures $(44,48,61,73,165)$. The rupture almost invariably occurs in the bony groove on the distal radius $(48)$. The cause might be mechanical, through laceration of the tendon by bone fragments or callus or by a crush $\mathbb{1}$ injury of the tendon during the hyperextension tratua $(49,181$, $188,192,198)$. In another theory a vascular aetiology is proposed; increased pressure in the non ruptured tendon sheeth due to hematoma or laceration of the resotendon might disturbe the blood supply causing degeneration and rupture of the tendon $(61,48,171)$. Tendon txansfer of the extensor indlcis proprius is the most commonly used procedure with excellent results $(165,181,194)$.

Thupture of other tendons have been mentioned in connection with a Colles fracture but are extreme1y uncomon $(44,118,138,156,174,199)$. Stenosing tendosynovitis is reported in $0.6-1.4 \%(30,103,174)$.

\subsubsection{Sudeck dystrophy}

Sudeck dystrophy is a term that encompasses a wide clinical spectrum and is closely related or identical with conditions like post-tramatic reflex dystrophy, post-traumatic sympathetic dystrophy, shoulder hand (finger) syndrome, osteoneurodystrophy and causalgic syndrome (7). The incidence in Colles fractures varies from $0.1 \%$ to $16 \%$ and should be suspected when pain, swelling and stiffness are out of proportion to the severity of the injury $(9,44,72,73,86,106,109)$. It leads to a high degree of disability (73). Three different stages can be distinguished (Table 3.5) $(7,90,106,186)$.

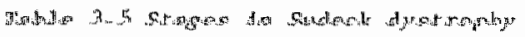

stage 1:

- pistiy andera

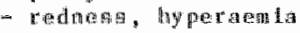

- pronounced palla out of proportion to the

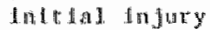

- hyperest furesta

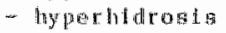

- redmess over the metacarpophatangend and

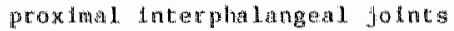

- 1. In titation of movement.

- afer jo weks begluning of spotty daminteralisation or polat demineralisation in the eplptystcal reglon asi seen on radlographs

stage 2:

- fug g f forst swelling

- tught shing skth

- tincresing diffuse pan
- hyperhidrosis, hyperaenda

- motion contlnues to decrease

- Joints become fixed

- acute nodules due to palmar fascits

- atroply of the subcutaneous tissues

- scanty halr growth after 1 year

- brittle nallis

- spotty demineralisation or polar demlneralisation

Stage 3

- hand : pale collor, cool and dry

- skin: thin, tightly stretched whth glossy appearance

- wide spread neuralgla

- stfff hand

- diffuse demineralisation of bone 
The aetiology is not yet clearly understood. Among contributing factors, sympathetic over-activity, wasonotor reflexes, circulatory insufficiency, oedena, traumatic fracture reduction, rereposition, frequent changes of casts, malunion, psychological factors and endogenous factors have been mentioned $(7,47,57,70,73,106,136,143)$. In the treatment sympathetic blocks, sympathectomy, guanethidine blocks, corticosteroids, vasodilatators, analgesics, immobilisation, active physiotherapy and hydroxyl tadical scavengers have been advocated $(42,57,70,78,106,136,192)$. Some authors believed that if activity is carried out from the beginning, this complication is very rare; they regarded active exercises to be the best prophylaxis $(7,103,136,148)$.

\subsubsection{Malunion}

No commonly accepted criteria for malunion could be found. Malunion, mostly resulting from redislocation, might cause linitation of motion, cosmetic deformity and pain (44). Some authors advised a corrective wedge osteotomy with interposing corticocancellous bone grafts, especially in young patients with an angulation deformity $(44,65,166,193)$.

\subsubsection{Loss of radio-ulnar integrity}

Loss of radio-ulnar integrity is caused directy by extension of the fracture into the joint or indirectly by shortening of the radius (86, 100). Symptoms include restricted painfull pronation and supination sometimes with a disturbing click, weakness of grip, persistant pain on compressing the distal ulna and radio-ulnar joint, protruding distal ulna and laxity of the distal radio-ulnar joint $(1,73,86,109,116)$. The latter can be assessed clinically by moving the uilnar head up and downwards in comparisson with the uninjured side $(66,113)$. Frykman (73) found an incidence of $19 \%$ and regard it an inportant cause of unsatisfactory functional end results. For most authors, resection of the distal ulna (Darrag procedure) is the treatment of choice for complaints resulting Erom loss of radio-ulnar integrity $(34,46,52,65,195)$. Good results, painless motion in the wrist region and improved cosmetic appearence have been reported after this procedure $(1,44,46,65,116,140)$.

\subsubsection{Post-traumatic arthritis}

Post-traumatic arthritis is reported from less then $5 \%$ to over $40 \%$ (4. $73,74,109,113,170)$. This discrepancy arises from the use of different definitions (86). Some based the diagnosis on symptoms of palnful motion and mechanical obstruction (44). Others on radlographic criteria like narrowing of the joint space, sclerasis, subchondral clearing and osteophyte formation $(17,74,170)$. It is seen espectally after intramaticular fractures. No reports on the onset were found. Sellected cases have been treated by wrist fuston, proximal row carpectomy or cotal prosthetic arthroplasty $(44,86)$.

\subsubsection{Loss of motion and function}

No generally accepted criteria for loss of motion and function were found. In Bacorn and Kurtzke"s (9) retrospective study of 2132 cases, only $3 \%$ had no permanent $10 \mathrm{~s} s$ of function. The most frequent permanent defect was reduced volar flexion in $95 \%$. Frykman (73) found $10^{\circ}$ or more loss of motion in $77 \%$ of 431 colles fractures. Loss of grip strength is recorded in 24 to $54 \%(9,31,73,164)$. Finger stiffness is found in 1 to $18 \%(73,74,159)$. Lloyd and Stangel (114) noted in $80 \%$ reduced strength of pronation and supination, being unrelated to the degree of malunion. 


\subsubsection{Persibtent pain}

bersistent pain is frequenty associated with previously mentioned complications. It $1 \mathrm{~s}$ described separately as this complaint might be the most annoying residual factor for the patient. Frykman (73) found persistent pain in 27\% of his patients. Castain (3i) reported moderate to severe pain in $39 \%$ in his serles. Wringing out clothes, turning doorknobs, heavy lifting, pronation and suplnation under stress appear to be frequently painful for a year after the injury (30). During the same pertod changes of weather might be associated with pain $(30,86)$.

\subsubsection{Dupuytren contracture}

Some authors mentioned the occurrence of a Dupuytren contracture in 0.2 to $3 \%$ of the cases $(9,31,39,44)$. Stewart et al (179) found in 23 of their 209 patients palmar nodules and bands, six months after the injury.

\section{10 Evaluation of the end results}

To evaluate the subjective, functional, cosmetic and anatomical end results after colles fractures, many different scoring systems have been used. Lidstrom (109) developed classifications to score the functional end result, anatomical end result and cosmetic end result (Table 3.6 , $3.7,3.8)$. These were used and modified by others $(17,73,162)$. Gartland and Werley (74) developed a functional end result score system, based on the Mc Bride's (128) disability evaluation (Table 3.9). It has been used by various authors $(36,50,56,69)$ and modifled by others $(26,31,43,115$, $121,152,162,178)$. Many authors designed their own systems or classifications for the functional and anatomical end result $(30,36,79,88,123,139$, $142,164,169,170,175)$

Table 3.6 Functional. and result classification of Lidstrom (109)

1. lixice llent:

Function of the wrist undmatred. No subjective symptons. Wo deformity. Loss at dorsal flexion or palnar flextion not exceeding is degrees.

2. Cood:

Function of the wrlst undmpired. Negligtble subjectlve symptoms. Deformity accepted if not ptoducing subject ive symptons.

3. Halr:

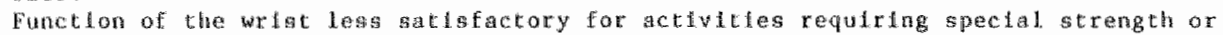
extlue movenents which must be avolded. Most pre-injury act 1 whtes possible. Loss of motion, even it sewere is accepted if not associated with subjective symptoms.

4. Poon:

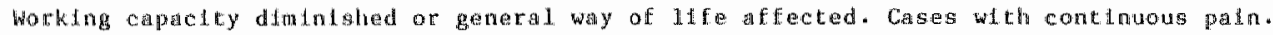

Table 3.7 Anatomical and result classiffeation of Ludstrotn (109)

l: No or laglgnfflcant deformley: dorsal angulation not exceeding o degrees or shortening of less than 3 mon

2. S1 ght deformity: dorsall angulation of 1-10 degrees and/or shortendmg of 3-6 ma

3. Noderate deformlty: dorsal angulatom of $1.1-14$ dagrees and/or shortentng of $7-11$ ma

4. Severe deformity: dorsal angulaton exceding 15 degrees or shortening of at 1 east $12 \mathrm{~mm}$ The shorenting is measured with the non-injured wrist as a standard 
1. Noreral appearance

2. Mormal appearance except for prominence of the wlat head

3. Slight radial deviation

4. Foderate to pronotuced radiat deviaton, dinner fork deforaty

Table 3.9 Functonal end result score systen of cartand and herley (74)

$\begin{array}{lc}\text { Mesidual deformity } & \\ \text { Puoninent ulnar styloid } & 2 \\ \text { Residual dorsal tile } & 2 \\ \text { Radial deviation of hand } & 2-3 \\ & \text { score range } 0-3\end{array}$

Subjective evaluation

Excellent: no pain, disablity or

ifritation of motiory 0

Good: occasional pain, slight lini-

cation of rotion, no disabliticy 2

Fair: occaslonal paln, sorne limita-

thion of motion, feeling of weakness

fir wist, no particular disablitity

if careful, actluties slightly re-

stricted

Poor: pain, limftation of motion,

disability, activities twore or less

markedly restricted

score range $0-6$

2

4.

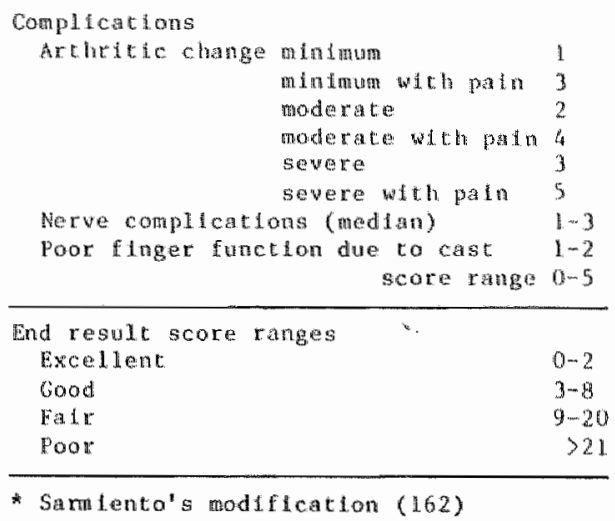

Complatititions

mintumen with patn 3

moxlerate with patn 4 severe

$\begin{array}{ll}\left(<45^{\circ}\right) & 5 \\ \left(<30^{\circ}\right) & 1 \\ \left(<15^{\circ}\right) & 3 \\ \left(<15^{\circ}\right) & 1 \\ \left(<50^{\circ}\right) & 2 \\ \left(<50^{\circ}\right) & 2 \\ & 1 \\ \text { joint } & 1 \\ \text { ured slde } & 1\end{array}$

Objectue evaluation Loss of dorsall fiexion. Loss of volar flexton Loss of ulare deviacton Loss of radial devtiation Loss of suptration Loss of pronation Loss of clrcumduction Pain in distal radio-ulnar joint Gripstrength $<60 \%$ of unfujured slde 1 *

The degree of disability, resulting from decreased notion, is an important factor in evaluating the functional end result after colles fractures. According to Swanson et al (185) and the Committee on Medical Rating of Physical Impairment ( 81 ), the degree of disability is equal in loss of dorsal flexion and volar flexion, equal in loss of ulnar deviation and radial deviation and equal in loss of pronation and supination. Loss of ulnat deviation and radial deviation gives 0.42 time the degree of disability as loss of dorsal flexion and volar flexion gives. These facts have not been considered in the various scoring systems.

In the evaluation of wrist injuries the uninjured wrist should serve as the lndividual standard because for practical purposes the left and right wrist are anatorical and functional bilaterally symetrical ( 56 , $71,134,157)$. The grip power however, is assumed to be $10 \%$ greater in the major hand $(14,105,144)$. In many scoring systems, the uninjured side $1 \mathrm{~s}$ not or only partly considered. 
The ultuate purpose of treatment of distal radius fractures is to preserve nomal function in the hand $(115,159)$. However, hand function after Colles fracture is seldomly mentioned (115).

No system to evaluate the speed of functional recovery could be found.

\subsection{End results}

The functional end result can only be judged from one year post-injury $(68,172)$. No reports were found indlcating from which time onwards the anatonical end result can be assessed. The cosmetic end result seems to watch generally with the anatomical result $(73,86,109)$, although many cases of considerable anatomical deformity had no corresponding cosmetic impalment in frykman's study (73). The use of different definitions, indications, criterla and scoring systems and the unequal populations makes comparison of treatment outcome in the various mostly retrospective studles very difflcult or even impossible.

Sarmiento et al $(159,162)$ compared results of their functional bracing In supination with retrospective studies of conventional plaster treatment. Although their method did not entirely prevent collapse of the fracture they concluded that the functional end result and anatomical end result are superior and that early function via functional bracing leads to early recovery of the range of motion and to a speedy rehabilitation. Bünger et al (26) published in 1984 a prospective study in which functional bracing in supination was compared to dorsal plaster splint immobilisation. After 6 months the anatomical and functionel result obtalned with functional bracing was significantly better than with immobilisation. The superior functional result was thought to be primarily due to the better anatomical result. Stewart et a1 (178) reported in 1984 results from a prospective study comparing functional bracing in supination, functional bracing with a below-the-elbow brace, and below-theelbow plaster treatment. They found no significant difference in anatomical and functional result or occurrence of complications 6 months after the injury.

The end results fron varlous studies are listed in Table 3.10.

Tabie 3.10 hind results

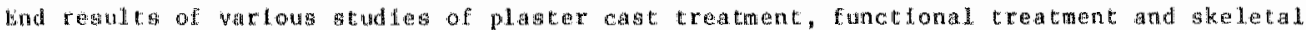
It tot ton.

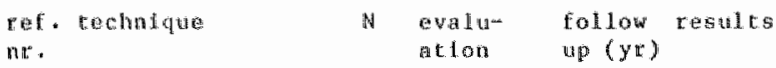

Plaser cast treatment

\begin{tabular}{|c|c|c|c|c|c|}
\hline 9 & mot ment loned & 2132 & own & $4=14$ & average disablitty:24\% loss of hand function \\
\hline 109 & $\begin{array}{l}\text { dorial plaster } \\
\text { hant deviation }\end{array}$ & 515 & L.nild d & $y-3$ & $\begin{array}{l}48 \% \text { loss of motion } \\
21 \% \text { falrf poor functional result } \\
37 \% \text { moderate to severe anatonical deformity } \\
40 \% \text { unsalsfactory cosmet } 1 \text { cesult }\end{array}$ \\
\hline 74 & $\begin{array}{l}\text { donsel and volar } \\
\text { splints } \\
\text { wolar flexlon } \\
\text { ulnar devlation }\end{array}$ & 60 & $6-1$ & 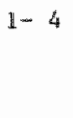 & $\begin{array}{l}32 \% \text { unsatisfactory functional result } \\
60 \% \text { unsatisfactory antomical result }\end{array}$ \\
\hline
\end{tabular}




\begin{tabular}{|c|c|c|c|c|c|}
\hline $\begin{array}{l}\text { ret. } \\
\text { nis. }\end{array}$ & tecton aque & 树 & $\begin{array}{l}\text { evalu- } \\
\text { ation }\end{array}$ & $\begin{array}{l}\text { collow } \\
\text { up (yt) }\end{array}$ & results \\
\hline 73 & $\begin{array}{l}\text { dorsal plascer } \\
\text { vartous pasterons }\end{array}$ & 430 & Lild & $2-5$ & 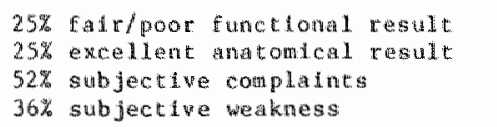 \\
\hline 17 & $\begin{array}{l}\text { dorsal plaster } \\
\text { ulnar deviation } \\
\text { pronation }\end{array}$ & 93 & Lid & $1-15$ & $\begin{array}{l}11 \% \text { fair or poor tunctond desult } \\
65 \% \text { excedent anatomical result }\end{array}$ \\
\hline 30 & $\begin{array}{l}\text { dorsal and wolar } \\
\text { splints, varying } \\
\text { volar flexton }\end{array}$ & 135 & Oi hen & mknowin & $\begin{array}{l}\text { 6\% poor funct lonal result } \\
14 \% \text { poor or bat anatomleal result }\end{array}$ \\
\hline 275 & $\begin{array}{l}\text { pritatary ullia } \\
\text { resection, }\end{array}$ & 42 & own & t & $\begin{array}{l}12 \% \text { bad functional resule } \\
60 \% \text { bad anatomical result }\end{array}$ \\
\hline
\end{tabular}

\begin{tabular}{|c|c|c|c|c|c|}
\hline 163 & $\begin{array}{l}\text { Samiento func- } \\
\text { thonal brace }\end{array}$ & 104 & $\begin{array}{l}6-\mathrm{w} \\
\mathrm{Eid}\end{array}$ & $6-23$ wh & $\begin{array}{l}10 \% \text { fall or poor functional result } \\
32 \% \text { falr or poor watonical result }\end{array}$ \\
\hline 159 & $\begin{array}{l}\text { Samdiento fune- } \\
\text { tional brace }\end{array}$ & 44 & $\begin{array}{l}C-W \\
\text { Lid d }\end{array}$ & short & $\begin{array}{l}18 \% \text { fall or poor functional rosult } \\
39 \% \text { moderate or severe deformity }\end{array}$ \\
\hline 26 & $\begin{array}{l}\text { 1. Sarmitento } \\
\text { funct.brace } \\
\text { 2. dorsal plaster } \\
\text { ulnar devlation }\end{array}$ & 145 & $\begin{array}{l}r_{n}^{n}-w \\
\text { Lid }\end{array}$ & 管 & $\begin{array}{l}\text { prospective study } 1984 \\
\text { l. abtalned stgatficant better functional } \\
\text { and anatomical result than } 2 \text {. }\end{array}$ \\
\hline 1.78 & $\begin{array}{l}\text { 1. Samilento } \\
\text { funct brace } \\
\text { 2. dorsal plaster } \\
\text { 3. below elbow } \\
\text { funct. brace }\end{array}$ & 243 & $\begin{array}{l}0-4 \\
L, 1 d\end{array}$ & $\frac{1}{2}$ & $\begin{array}{l}\text { prospectlve study } 1984 \\
\text { no signiflcant difference in anatomlcal and } \\
\text { functional result between the } 3 \text { mothods }\end{array}$ \\
\hline
\end{tabular}

\begin{tabular}{|c|c|c|c|c|c|}
\hline 50 & whar plinneng & 23 & $G-W$ & $1-3$ & $18 \%$ unsatsfactory functiond resuld \\
\hline 515 & Whar plandrg & 51 & $6-6$ & -10 & $16 \%$ poor functlonal result \\
\hline 36 & 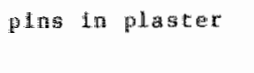 & 33 & $G^{-4}$ & $1 \frac{3}{2}-5$ & $\begin{array}{l}\text { 6\% fiatr functional result } \\
33 \% \text { signiflcant rediglocatedon }\end{array}$ \\
\hline 164 & plas in plaster & $2 t_{4}$ & otm & $1-9$ & 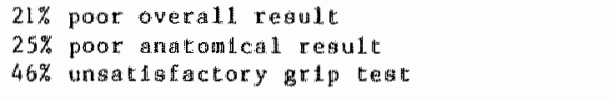 \\
\hline 79 & plas in plaster & 4.5 & lown & $b^{2}-2$ & $\begin{array}{l}\text { 14\% ungetdafactory functional and anatom- } \\
\text { cal results }\end{array}$ \\
\hline 43 & $\begin{array}{l}\text { Roger funderson } \\
\text { ext. fixation }\end{array}$ & 60 & own & 2 & $\begin{array}{l}15 \% \text { fair or unsatidactory bubjectlue } \\
\text { results. 10\% Ealir or poor overall result }\end{array}$ \\
\hline 115 & Rusty rods & 33 & $6-w$ & $2 \frac{1}{2}$ & $3 \%$ poot functlonal result \\
\hline 122 & Intern. firation & 15 & $\begin{array}{l}\text { varlous: } \\
\text { crterta }\end{array}$ & $1-9$ & $\begin{array}{l}20 \% \text { falr or poot subjectlue result } \\
53 \% \text { falr or poor objectloe regult }\end{array}$ \\
\hline
\end{tabular}




\section{12 Prognostic factors of the functional end result}

\section{- General factors}

General factors like age and sex have no $(76,109)$ or only very little (73) relationship to the functional end result. Bacorn and kurtzke (9) however, regarded age to be an importat prognostic factor.

\section{- Eracture type}

Cominuted fractures, intra-articular fractures especially through the distal radomlnar joint and ulnar styloid tractures seem to be associated with poor prognosis $(5,73,74,109,139)$. S\$lund et al (172) noted a correlation between fracture type and duration of incapacity for work. older et al (139) found that the prognosis of the functional end result can be predicted by the severity of the fracture at the time of injury.

\section{- Anatonical end result}

Controversy exists on the influence of the anatomical end result on the functional end result. Clinical observation, impression or just belief have frequently been used to assume an important influence $(10,19,42,46$, $67,86,131)$. A positive correlation between anatomical and functional end result is reported in some studies $(17,30,31,76,109,196)$ but denied in others $(56,175,197)$. Stewart et a1 $(178,180)$ found in a prospective randomised trial six months after the trauna no correlation between functlonal end result (Gartland and Werley"s system) and anatomical end result (Lidstroms system). However, they found a clear correlation between the functional end result and the severity of the initial displacement. Bacorn and Kurtzke (9) clalmed a correlation between externally visible residual deformity and disability. Their study is often used to conclude a causal relationship between anatomical and functional end result ( 36 , $43,120,158)$. Wey et al (196) clatmed that in $92 \%$ the function could be assessed from the final radiographs. However, many verified that a port anatomical result does not preclude a good functional result and that a good anatomical result does not guarantee a satisfactory functional result $(17,30,56,71,109,139,159,164,175,180)$. The influence of the residual volar angle shift, radial shortening and radial angle shift on the functional end result is also subject to controversial oplinions $(30,31$, $73,74,115)$

\section{- Conplications}

The occurtence of major complications like Sudeck dystrophy, nerve injury and loss of radio-ulnar integrity are significantly associated with unsatisfactory functional results (73). Lippman (113) and Lidstrom (109) considered. Loss of radio-ulnar integrity the most common cause of poor functional results.

\subsection{Concluston and discussion}

The colles fracture is a frequent encountered injury with a rather high percentage of unfavourable end results and complications. Definition, classification, anaesthesla, reduction, method of treatment, management of the post-reduction period, evaluation of end results, treatment and defintions of the various complications are subject to different opinions. Little is published about minimally displaced fractures, compartment syndrome, soft tissue injury and speed of recovery. The most controversial aspect remains the fracture treatment. Many different methods have been advocated. These range from anatomical reduction and 
meticulous maintenance of the position to a tull collapse of fracture fragments and from long imobilisation to early motion and function.

A central theme in the treatment is the influence of the anatomical end result on the functional end result. The authors" oplinion on this is reflected in the chosen method of treatment. The influence however, remalns usettled in literature. "Common sense" often is the only argument for the existence of a causal relationship between the anatomical and functional end result. If figures are reported, these reflect correlations found between the anatomical and functional result. Whether a positive correlation exists is still disputed. However, even if a positive correlation would exist, it is not justified to conclude that in that case a causal relationship exists as we11. Since both items wight depend on mutual factors like severity of the injury, type of fracture, fracture reduction and age, a positive correlation can be found without the existence of a causal relationship. This means that changing the anatomical result will not then alter the functional result despite a positive correlation. No efforts have been made to really investigate a causal relationship between the anatomical and functional end result.

The most frequently used scoring systens to evaluate end results are unsatisfactory because the uninjured side is not or only partly used as the individual standard, important parameters are not defined, point scales do not correspond with the guidelines of the Commitee on Medical Rating of Physical Impalment (81), hand function is not considered, and the final graduations are arbitrary.

It is difficult to estinate the value of the various different methods of treatment, including functional bracing, as comparison of results from the literature seems almost impossible and only very little well documented comparitive prospective clinical studies have been performed. 



\section{CHAPTER 4}

\section{DESIGN OF THE STUDY}

In the design of a study aiming to establish the application field of functional treatment of Colles fractures by comparing results from this kind of treatment with conventional below-the-elbow plaster treatment, first the type(s) of functional treatment to be used in the study should be determined. Various degrees of early motion and function are possible. Too much early motion and function however, might result in redislacation of initially reduced fractures and thus in a bad anatomical result. Most likely, this will happen more frequently in unstable fractures than in stable fractures. If a strong causal relationship exists between the anatomical and functional end result, the degree of early motion and function is rather restricted as redislocation should be prevented. On the other hand, if no strong causal relationship exists, more early motion and function can be tolerated as a possible redislocation is hardly detrimental for the functional end result. The study focusses on that optimal early motion and function in which the possible advantage of functional treatment is not undone by disadvantages resulting from reduced stabilisation. Fracture stability and the kind of relation between anatomical and functional result appear to be important items in the search for this optimal early motion and function. Whether the optimal early motion and function varies with the fracture stability, needs to be investigated. The existence of a causal relationship between anatomical and functional end result has not been settled up to now; this needs investigation as we 11 . A proper methodological way to investigate the existence of a causal relationship would be to study the correlation between anatomical and functional end result in a clinical experiment in which the anatomy is manipulated while all other important unfluential factors are kept constant. However, such an experiment is not possible on ethical grounds. Another way to investigate the existence of a caugal relationship is to evaluate the correlation between anatomical and functw ional end result while the influence of other important factors is kept constant by means of statistical analytical methods. This 15 possible and performed in this prospective clinical study.

At the start of this study (1981) Sarniento's functional bracing in suplnation was the only reported type of functional treatment of colles fractures. Another type of functional treatment described in 1984 (178) could not be implemented in this study. Sarniento's method is propagated regardless of the fracture stability. Although early volar flexton and ulnar deviation are permitted, pronation and supination are restricted. This is in contrast to conventional below-the-elbow plaster treatnent that does not fully restrict pronation and supination. In this respect, the conventional treatment is even slightly more functional than Sarmiento's method. To fulfil the aim of the thesis, a loglcal first step is to compare Sarmiento's functional bracing in supination with below-the-elbow plaster treatment. If no contra-indications are found, functional bracing with more early motion and function needs to be 
tested in a second step as Hell. Based on the above mentioned considerations, a logical cholce in that case is to permit, besides early volar flexion and unar deviation, some pronation/supination as we11. In addition for minimally displaced fractures a method can be investigated that does not restrict any motion at all. This chalce is based on the fact that minimally displaced fractures are not reduced and are generally regarded to be stable, and on the assumption that if the trauma does not result in gross anatomical displacement, it is not very likely that early wotion and function will do. Whether still another type of functional treatment needs to be tested depends on the results from the first two investigation phases and on the outcome of the investigation on the causal relationship between anatomical and functional end result.

In retrospective studies, Sarmiento claimed a faster functional recovery and a better functional and anatomical end result with his method, compared to conventional plaster treatment (Paragraph 3.11). Therefore, in this prospective study, both the speed of functional recovery and the functional end result are used as a criterium for treatment outcome comparison. The anatomical end result is not used as a criterium because the causal rellationship between the anatomical and functional end result 1 unrevealed. Different methods of treatment might lead to different complications. Therefore, the accurrence of complications is added as a criterlum for comparison of treatment outcome.

As the common score systems to evaluate the functional results are unsatisfactory (Paragraph 3.13), and no system to evaluate the speed of functional recovery was found in literature, another system is developed for this study.

In the literature many aspects of the colles fracture lack commonly accepted definitions. In this study the following definitions are used: Colles fractures:

An injury of the forearm and wrist resulting in a complete transvers break of the distal $3 \mathrm{~cm}$ of the radius in adults, with dorsal displacement and/or dorsal angulation of the distal fragment or without displacement of Eragments

Minimally displaced fractures:

A colles fracture with a volar angle of $0^{\circ}$ or more (i.e. Without dorsal angulation)

Anatomical result:

The volar angle, radial angle and radial length difference between injured and uninjured side and the radial shift

Intial displacement:

The anatomical result after the trauma

Quality of reduction:

The anatomical result after reduction

Anatomical end result:

The andomical result one year after the trauma

Functional result:

The score of the evaluation system used in this study, reflecting the patients disability

Functional end result:

The functional result one year after the traumat

Functional recovery:

The improvement of the functional result during the first year 
Based on the previous reflexions the following hypotheses were formulated:

Hypothesis 1

Functional treatment of colles fractures with Sarmiento"s functional bracing in supination is superior to conventional plaster treatment according to the following criteria:

- faster functional recovery

- better functional end result

- less complications

If results of a clinical study testing hypothesis 1 do not indicate inferior results of Sarmiento's functional bracing over conventional plaster treatment, hypothesis 2 and 3 will be tested as well:

Hypothesis 2

In displaced fractures, functional treatment with a below the elbow functional brace that restricts dorsal flexion and radial deviation is equal or superior to Sarmiento's functional bracing and conventional plaster treatment according to the above mentioned criteria.

Hypothesis 3

In minimally displaced fractures, functional treatment with a bandage is equal or superior to Sarmiento"s functional bracing and conventional. plaster treatment according to the above mentioned criteria.

Hypothesis 4

A causal relationship exists between the anatomical end result and functional end result.

These hypotheses were worked out in a prospective clinical study as described in the next chapter. 


\section{CHAPTER 5}

\section{METHODS}

\subsection{Patients}

From October 1981 till way 1983, all patients with a colles fracture and united epiphyseal plates treated in the Department of General Surgery of the University Hospital Mastricht, The Netherlands, entered the study. Exclusion criteria were:

- accompanying other fracture of the same limb

- open fracture

- a fracture older than 3 days

- bilateral fractures

- multitrauma injury

- previous fractures of the same $11 \mathrm{mb}$

- pre-existing impaiment of the same limb

- continuation of treatment el sewhere

Wi thd rawa 1 criteria were:

- mental or physical unability to cooperate

- persisting volar angle $<-5^{\circ}$ after reduction

- more than two uissed follow ups

\subsection{Clinical trials}

The study consisted of two clinical trials:

1. Patients were allocated into two different treatment groups:

- "Conventional" or "CON", treated with a conventional below-theelbow plaster splint.

- "Sarmiento" or "SAR" treated with Sarmiento's brace in supination. "The allocation criterium was odd or even day on the furst vist. One year after the start, provistonal results in the Sarmento group appeared slightly better than in the conventional group. To complete the next step in the research design, the second clinical trial started.

2. Patients were allocated into the following two groups:

- "Sarmiento" or "SAR", treated with Sarmiento's brace in suplnation.

- "Functional" or "FUN": displaced fractures were treated with a functional below-the-elbow brace restricting dorsal flexion and radial deviation; minimally displaced fractures were treated with a. bandage.

In the second trial, numbered forms in the sequence three times functional, one time Sarmiento, were used for the patient allocation. (In this way, the total in the Sarmiento group would not become too large.)

As a result of the two clinical trials, three groups of differently treated patients were formed. 


\subsection{Intelal managenent}

The initial management was performed by the surgical resident on duty. The dlagnosis was made on clinical suspicion and radiographic confirmation. Circulation, nerve function, skin integrity and accompanying injuries were checked. Based on Sarmiento's Fracture classification, two kinds of fractures were distinguished; displaced (Type 2 and 4) and aninimally displaced (Type 1 and 3) fractures. Displaced fractures were intrafocally anaesthesised with $10 \mathrm{ml}$ lidocaln $2 \%$. Subsequently traction was applied for $15 \mathrm{minutes}$ with chinese fingertraps and a weight of $4 \mathrm{~kg}$ pulling a sling ower the upperam. Reduction was performed in pronation (Figure 5.1). The criteriun for adequate reduction was a volar angle of $0^{\circ}$ or more. If inadequate, reduction was tried only once more; if a wolar angle less than $-5^{\circ}$ was obtained, the patient was excluded from the study. Minlmally displaced fractures were not reduced.

In the conventional group all patients were treated with a below-theelbow dorsal plaster splint with the wrist in slight flexion and slight unar devlation. Pronation and stipination were not completely restricted as the cast did not extend above the elbow (Figure 5.2).

In the Sarmilento group all cases were treated initially with an abovethe-elbow dorsal plaster splint with the forearm in supination and the elbow in $90^{\circ}$ flexton (Figure 5.3).

In the functional group all patients were treated initially with the sane below-the-elbow dorsal plaster splint as in the conventional group (Figure 5.2).

A11 patients received information concerning the injury an instruction on exerctses both verbally and by means of a printed form (Addendum 1 ).

\subsection{Management in the post reduction period}

One day after the initial management, a11 patients returned for a plaster check up. If too tight, the plaster was adjusted. 6 to 9 days after the trauma, all. patients attended the ontpatient clinic:

In the conventional group the below-the-elbow plaster splint was left in situ for another 3 weeks. A new bandage was applied over the splint to correct for loosening due to decreased swelling. This was repeated one week later.

In the Sarmiento group the above-the-elbow plaster splint was changed for an above-the-elbow functional brace with the forearm in supination. Durlig this procedure, continuous traction was applied by chinese fingertraps and a welght pulling the humerus. Dorsal flexion, radial deviation and pronation were restricted. The last $45^{\circ}$ elbow extension was also restricted. Volar flexion and ulnar deviation were unrestricted (Figure $5.4)$

In the functional group all patients with displaced fractures got their below the-elbow plaster splint changed for a below-the-elbow functional brace. The changing procedure was performed as in the Sarmiento group. The brace restricted dorsal flexion and radial deviation; volar flexion, ulnar deviation, pronation and supination were not restricted (Figure 5.5). All patients with minimally displaced fractures were treated with a bandage after removal of the plaster splint. The bandage allowed motion in all directions (Figure 5.6 ). 
Figure 5.1 Anaesthesia and reduction
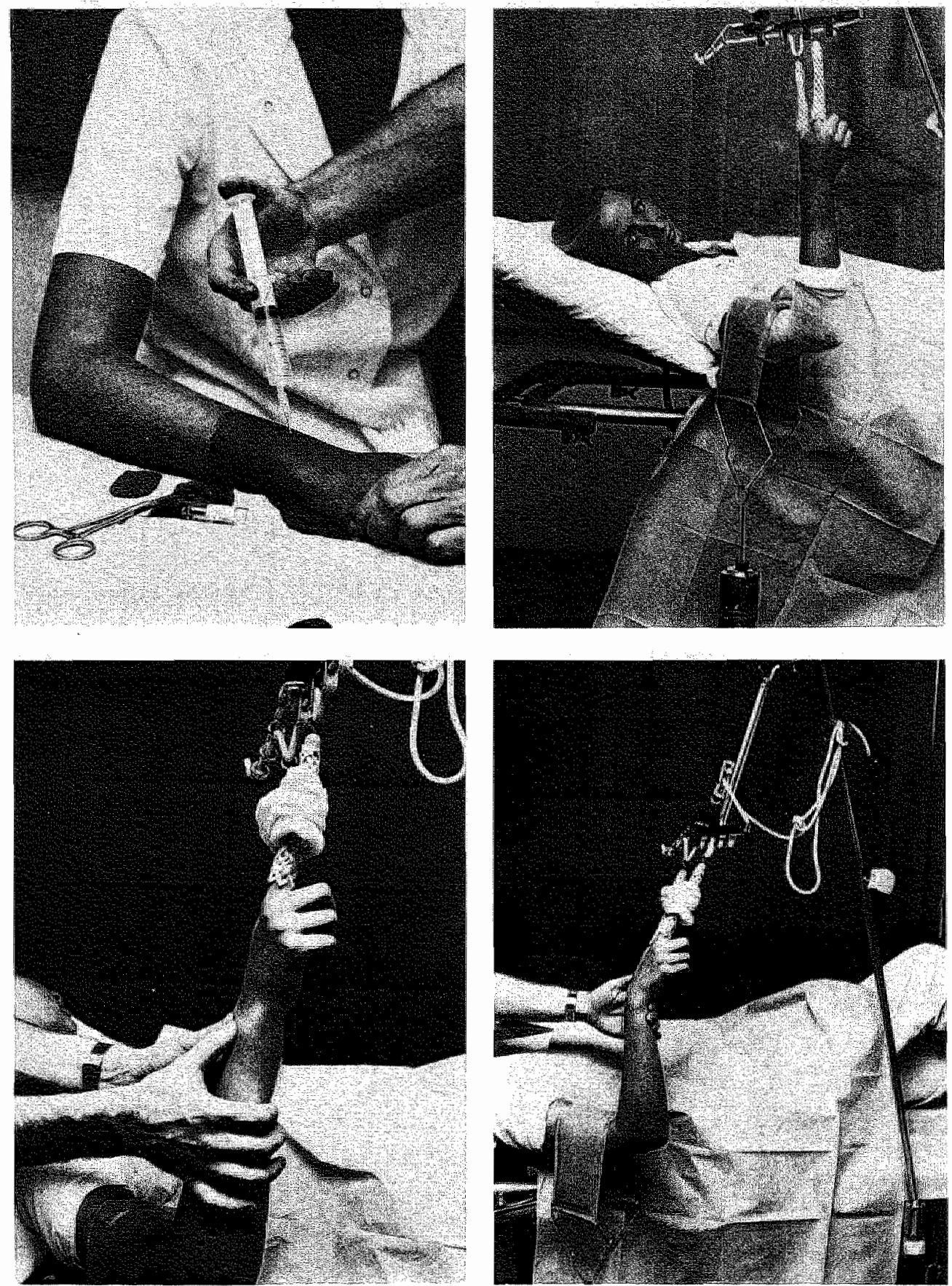

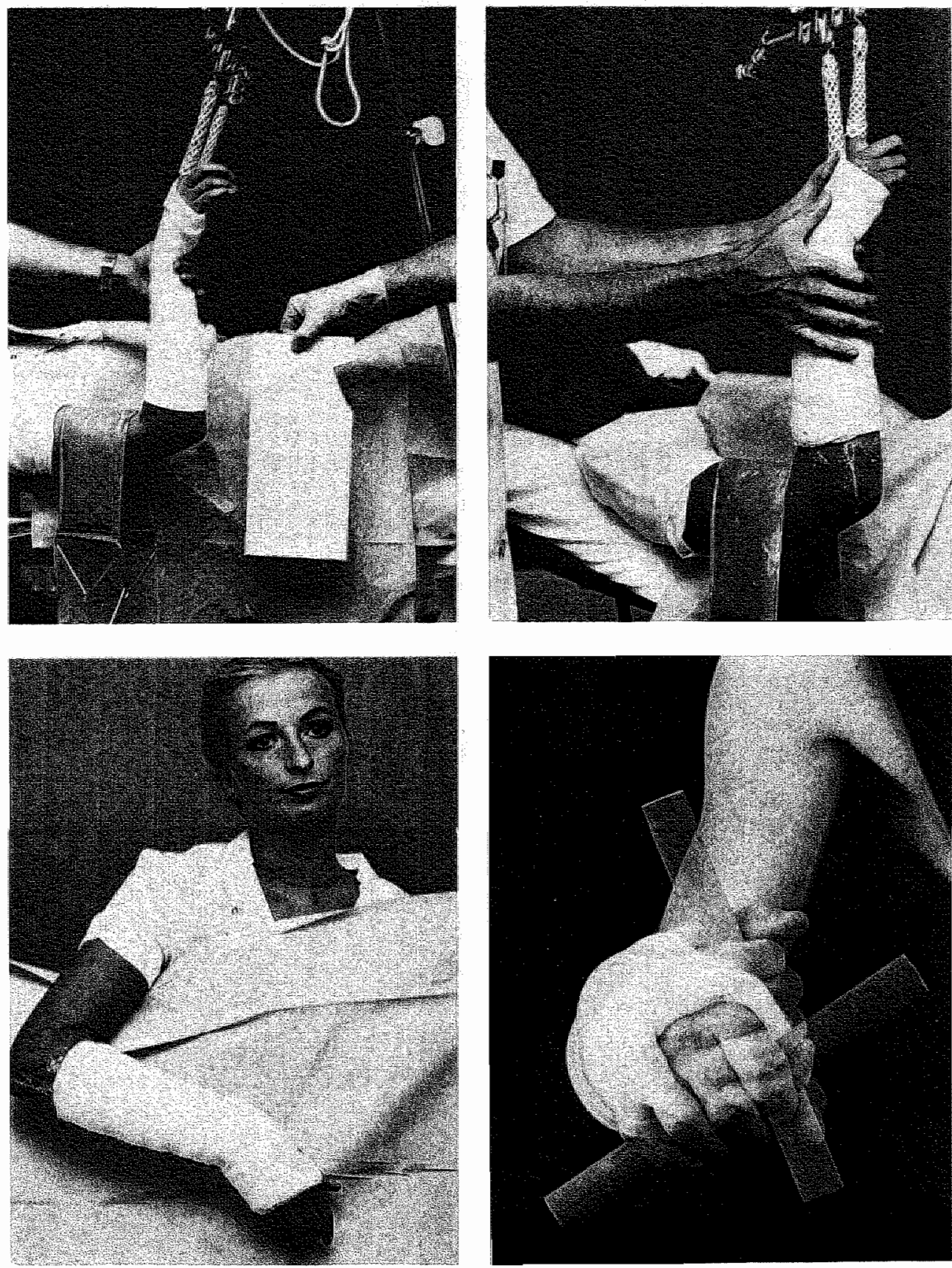
Figure 5.3 Above-the-elbow plaster splint with the forearm in supination
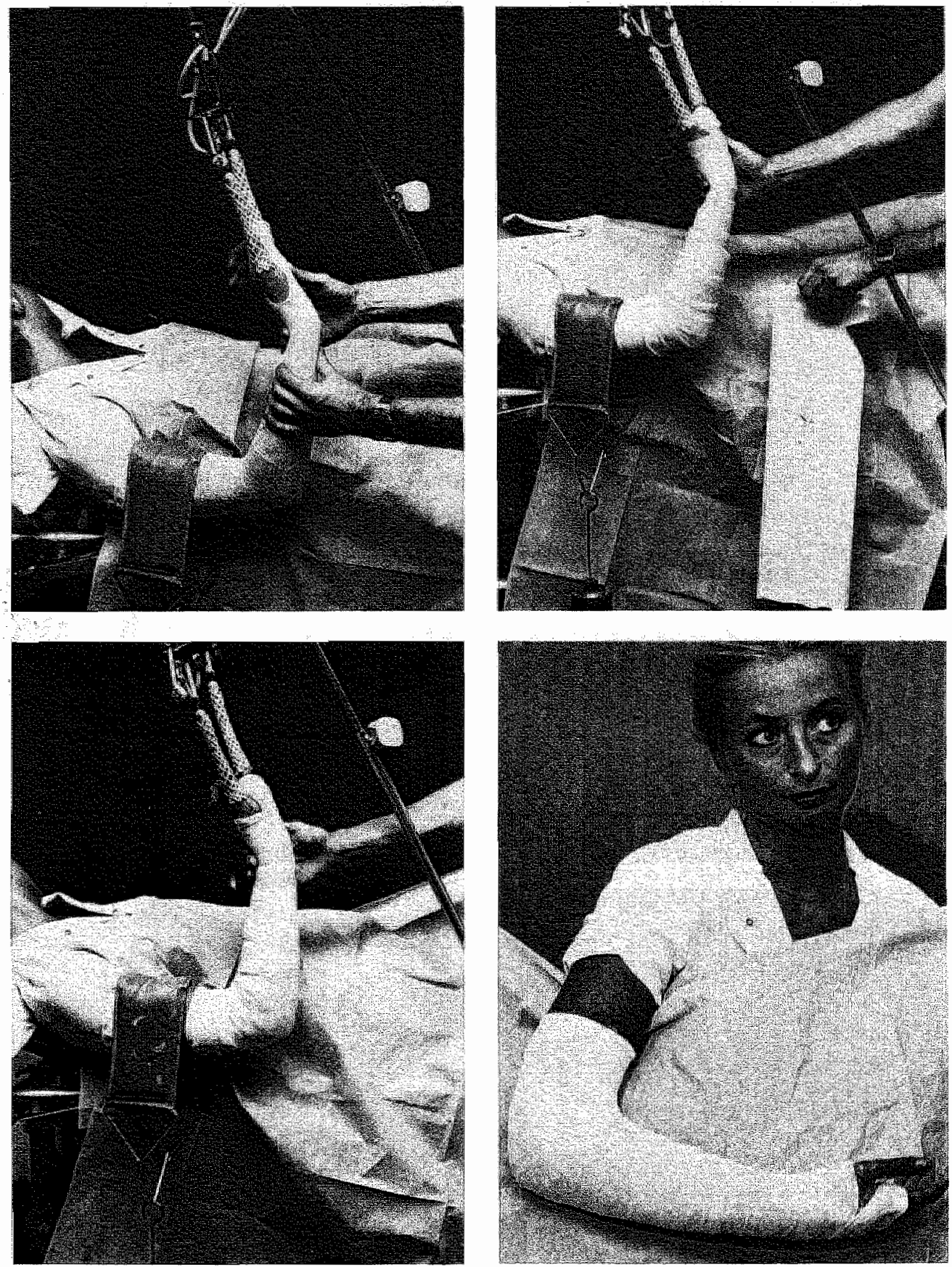
Fifgure 5.4 Samiento's above-the-elbow brace
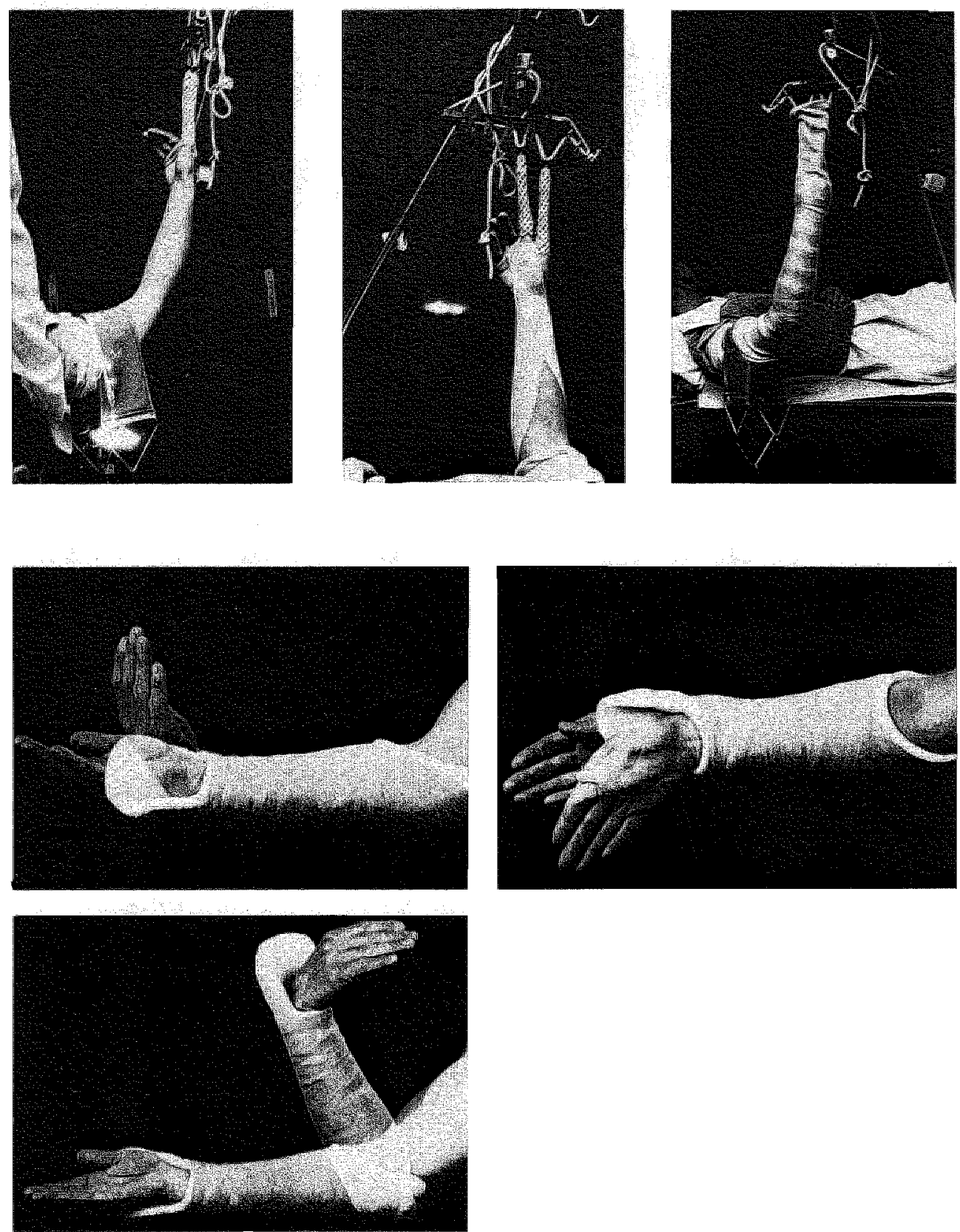
Figure 5.5 Functional below-the-elbow brace
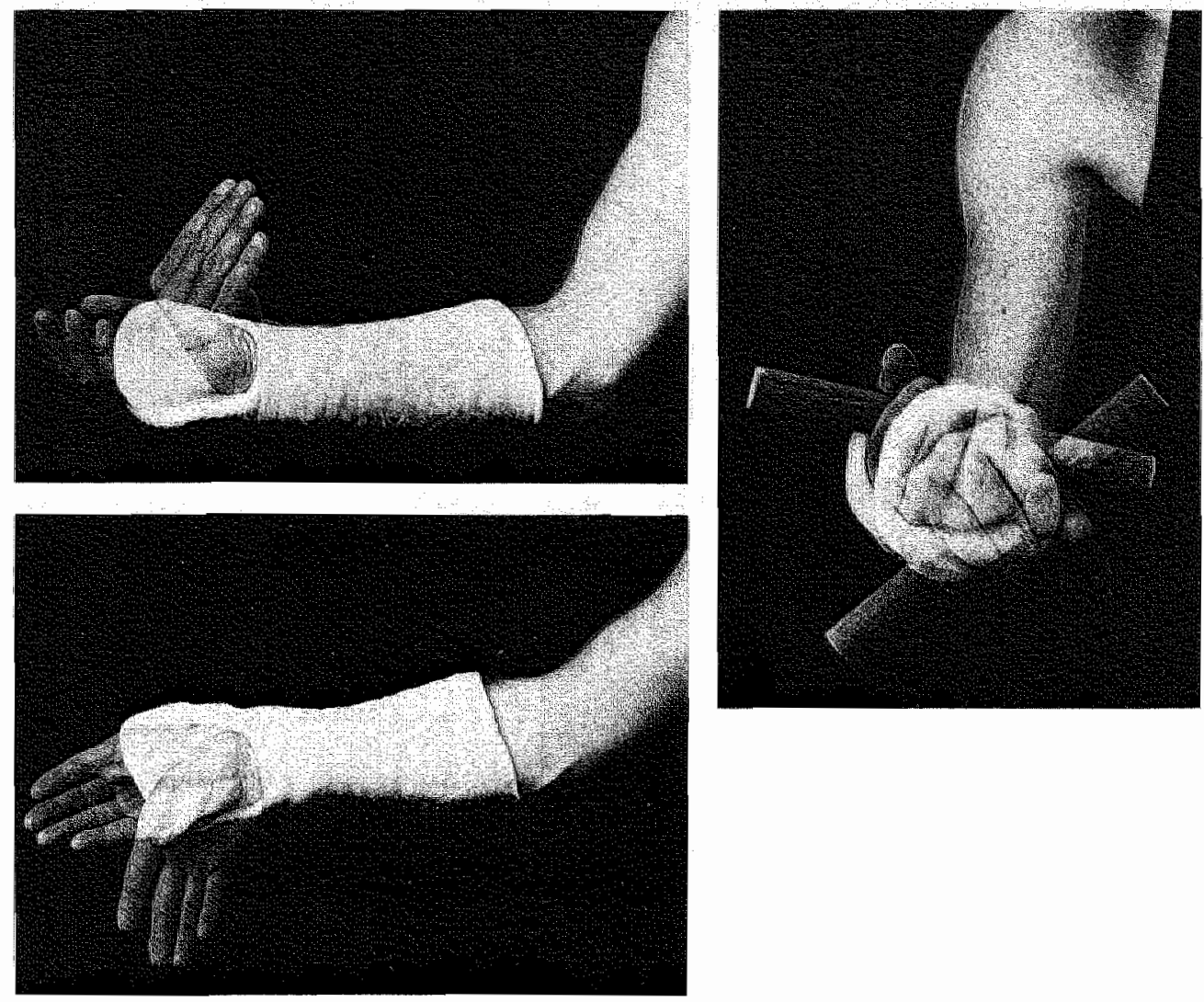

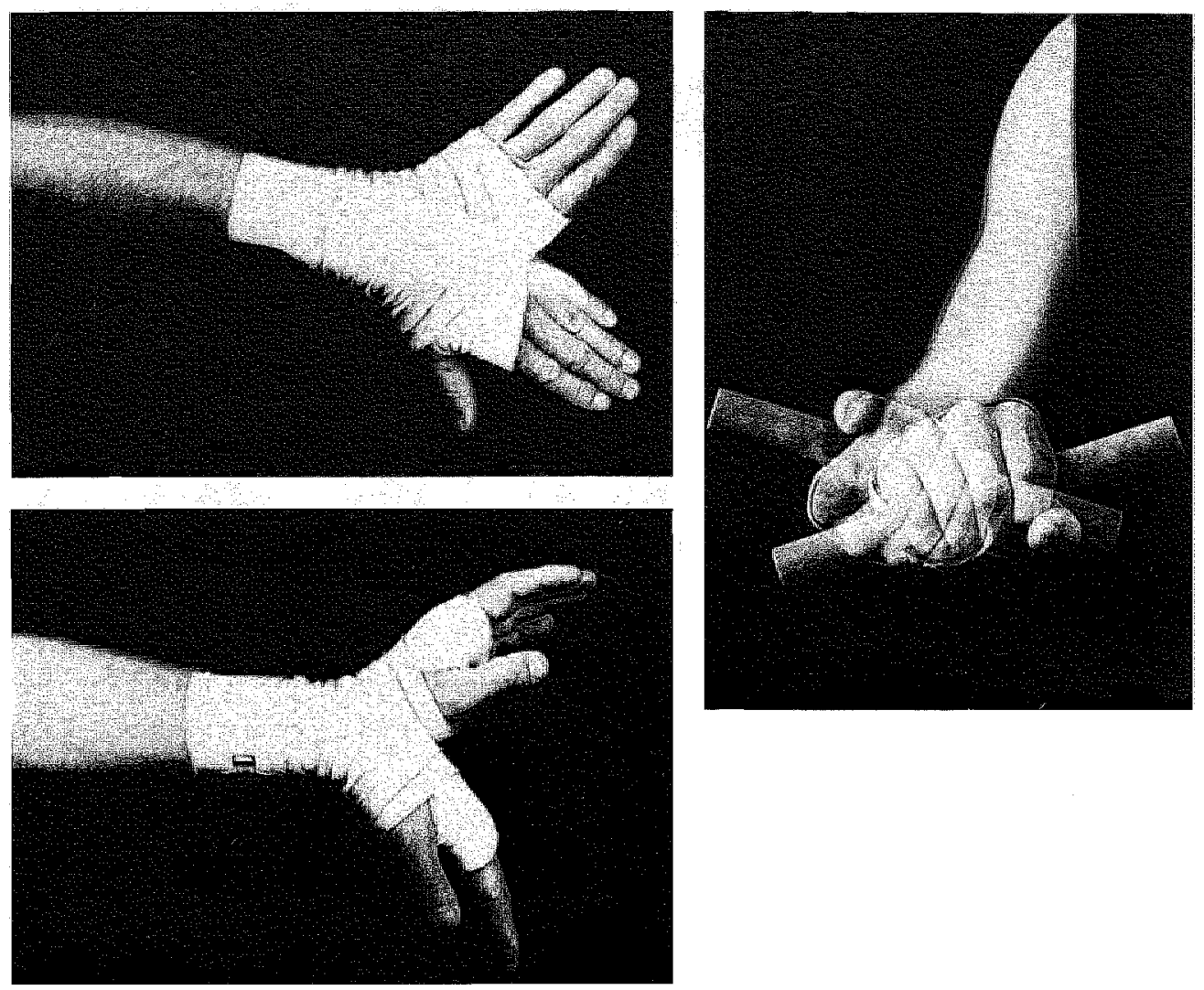

Cellona ${ }^{(\mathbb{P}}$ plaster of Paris was used for the plaster splints. The "Sarmiento" $^{\prime \prime}$ and the "functional" brace were made of Baycast ${ }^{\mathrm{B}}$. This material was selected because it is light, whilch is important to facilitate early motion and function. Tensoplast ${ }^{B}$ adhesive strappings were incorporated in the braces and flxed to the skin to prevent shifting (Figure 5.4). Patients in the Sarmiento group and functional group received new instructions on exercises, verbally and on a printed form (Addendum 2). Patlents in the conventional group were advised to continue their original exercises.

Information was obtained on the dominant hand, profession, and on possible prevlous fractures and impairment of the upper extremties.

One and two weeks post-trama, radiographs of the injured wrist were made to check the position. Rereduction was performed if redislocation, resulted in a volar angle less than $-10^{\circ}$ or a radial angle more than $15^{\circ}$ different from the uninjured side (radiographs of the uninjured wrist were made one week post-trauma). The rereduction was performed by suspending the arm by means of chinese fingersplints after $i \cdot v$. diazepam 
medication. After the rereduction the same treatment device as before the procedure was applied.

The management in the post reduction period was caried out by the author.

The treatment during the first 4 weeks is outlined belaw:

\begin{tabular}{|c|c|c|c|}
\hline Group & 1 week & 3 weeks & Possible motion \\
\hline conventional & $\begin{array}{l}\text { plaster splint } \\
\text { below-the-elbow }\end{array}$ & $\begin{array}{l}\text { plaster splint } \\
\text { below-the-elbow }\end{array}$ & $\begin{array}{l}\text { pronation } / \\
\text { supination }\end{array}$ \\
\hline Sarmiento & $\begin{array}{l}\text { plaster splint } \\
\text { above-the-elbow } \\
\text { in supination }\end{array}$ & $\begin{array}{l}\text { functional brace } \\
\text { above-the-elbow } \\
\text { in supination }\end{array}$ & $\begin{array}{l}\text { volar flexion } \\
\text { ulnar deviation }\end{array}$ \\
\hline \multirow[t]{2}{*}{ functional } & $\begin{array}{l}\text { plaster splint } \\
\text { below-the-elbow }\end{array}$ & $\begin{array}{l}\text { displaced: } \\
\text { functional brace } \\
\text { below-the-elbow }\end{array}$ & $\begin{array}{l}\text { volar flexion } \\
\text { ulnar deviation } \\
\text { pronation / } \\
\text { supination }\end{array}$ \\
\hline & & $\begin{array}{l}\text { mintma11y displa- } \\
\text { ced: bandage }\end{array}$ & all motions \\
\hline
\end{tabular}

5.5 Management in the rehabilitation period

Four weeks (28-3i. days) after the trauma, the plaster, brace or bandage was removed in a 11 cases and instructions were given verbally and in writing to perform exercises (Addendum 3). If motion and/or grip power appeared less than $1 / 3$ of the uninjured side at 6,10 or 14 weeks posttrauna, physiotherapy was prescribed, consisting of ultrasound, fango and active exercises without causing pain. The outpatient department was attended at scheduled checkpoints; 4 weeks, 6 weeks, 10 weeks, 14 weeks, 26 weeks and 1 year after the trauma. At these checkpoints complications were dealt with and data were recorded, necessary for the study (paragraph 5.6, 5.7). The management in the rehablitation period was carried out by the author.

5.6 Diagnosis and management of complications

1. complications due to cast or brace

Pressure sores and abrasions when encountered at the outpatient clintc were treated by adjustment of the plaster cast or brace and wound dressing. Shifted braces were replaced and refixed to the skin.

2. redislocation needing rereduction is discussed in Paragraph 5.4.

3. nerve injury

The diagnosis was based on WMG-studies. Indication for EMG Was numbness and or paraesthesia in the hand, appearing after the injury and existing for four weeks. If nerve compression was diagnosed, no treatment was given during the following four weeks. If the complaints still remalmed, operative decompression was performed. If the complaints disappeared in the last four weeks or if the patient refused treatment, no operation was performed. Signs of nerve compression immediately after the accldent were never found. 
4. tendon injury

The function of the finger tendons was tested at every checkpoint from 4 weeks onwards. Rupture of the extensor pollicis longus tendon (Figure 5.7) Was treated by indicis proprius tendon transfer. Stenosing tendosynovltus was treated with two local corticosteroid injections. If umsuccessful, operative release was performed.

Figure 5.7 Spontaneous tupture extensor pollicls longus tendon

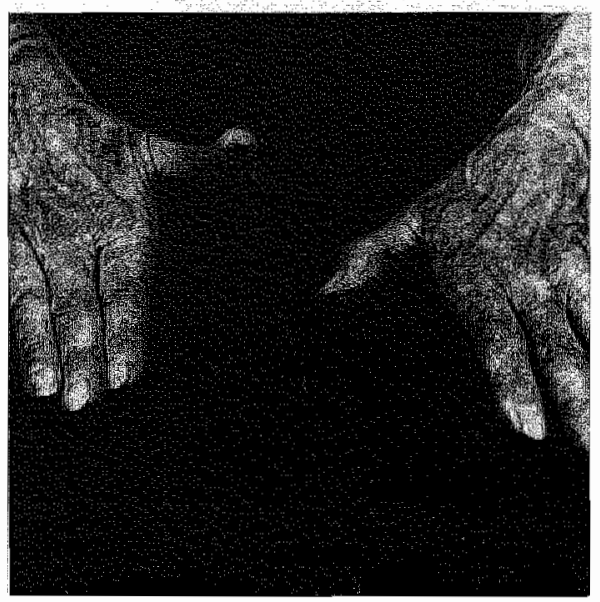

Figure 5.8 Sudeck dystrophy

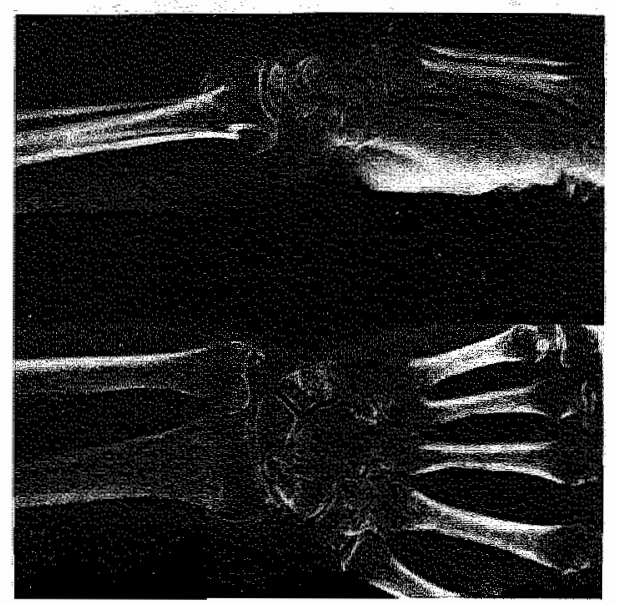

5. Sudeck dystrophy

Sudeck dystrophy is a rather vague entity. To standardise the diagnasis if the three stages of Sudeck dystrophy, the following criteria were chosen, which were based on Table 3.5 :

Stage 1: if three or more of the following symptoms were present: pronounced pain, swelling, hyperemia, hyperaesthesia, hyperhidrosis, restriction of motion less than $1 / 3$ of the non-injured wrist.

Stage 2: lf besides skin atrophy or polar deminerallsation of the bone (Flgure 5.8), two or more at the above mentioned symptoms were found.

Stage 3: a pale, stiff hand with dry skin and diffuse demineralisation. ThHs stage was not encountered.

Treatment in stage 1 and 2 consisted of active physiotherapy without causing pain and analgetics.

6. Loss of radio-ulnar integrity

The diagnosis was based on one or more of the following symptoms:

- persistant tenderness and compression pain over the distal ulna and radiomulnar joint at 26 and 52 weeks.

- pain during pronation, supination and ulnar deviation at 26 and 52 weeks.

- a cllck or black whlle rotating.

- Laxity of the distal radio-ulnar joint.

Loss of radio-ular integrity, disturbing the patient, was an indication for resection of the distal ulna.

7. Post-traunatic arthritis

This complication was defined by sclerosis of joint surfaces, subchondral clearing or formation of osteophytes present on radiographs one year after the trauna while absent on the initial radiographs. 


\section{Loss of motion}

The diagnosis was made if dorsal flexion, volar flexion, radial deviation, ulnar deviation, pronation or suplnation appeared less than $2 / 3$ of the un-injured side, one year post-trauma.

9. Dupuytren's disease

The diagnosis was based on the development of palmar nodules and bands. Although Dupuytren"s disease was found in some cases, no contractures developed during the study and no treatment was given.

The complications post-tramatic arthritis and loss of thotion were diagnosed at the end of the study. Therefore, the management and treatment are not discussed in this chapter.

\subsection{Parameters}

During one year follow-up, parameters were scored or measured in a standardised way to evaluate results of the study. These parameters were selected from the review of 1 terature and from tests of daily life activities. In Table 5.9, the follow-up schedule of the paraneters is indicated; the "complaints" were recorded through a standardised questionalre. The "motion in the wrist region" was recorded with an angle goniometer and a specially designed rotation goniometer (Figure 5.10). The "motor functions of the hand" were assessed by a series of standardised tests. The criteria for making a fist, finger extension and opposition were respectiwely: touching the palm of the hand, full extension to $0^{\circ}$ and touching the 1ittle finger with the thumb. The grip power was measured with a Jamar hand dynamometer as adviced in the literature $(14,102)$. The "signs and symptoms" were scored by comparison with the uninjured side. The scorig of the "cosmetic appearance" was based on Lidströms classification (Paragraph 3.10). The "radiographic parameters" were measured with a specially designed measurement device (Figure 5.11).

Figure 5.10 Rotation goniometer

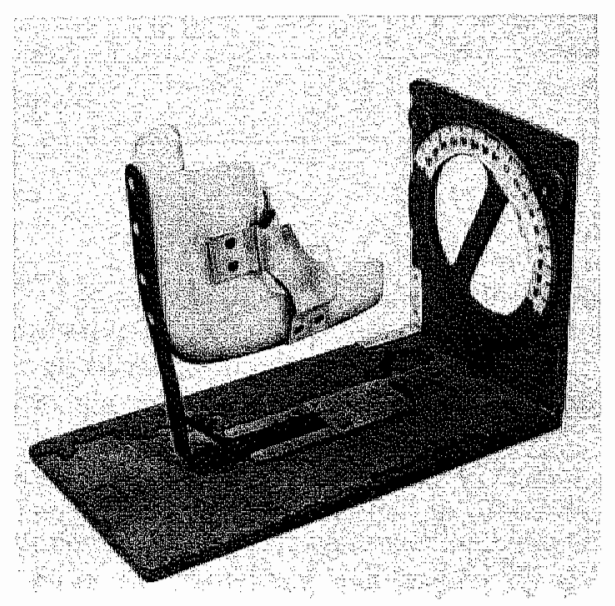

Figure 5.11 Radiographic paraneter measurement device

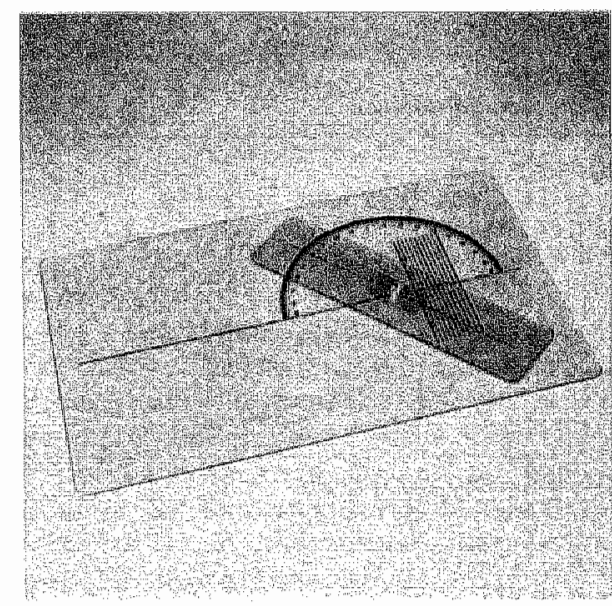




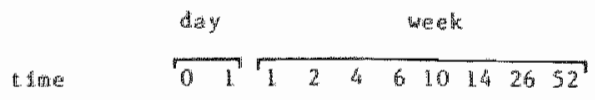

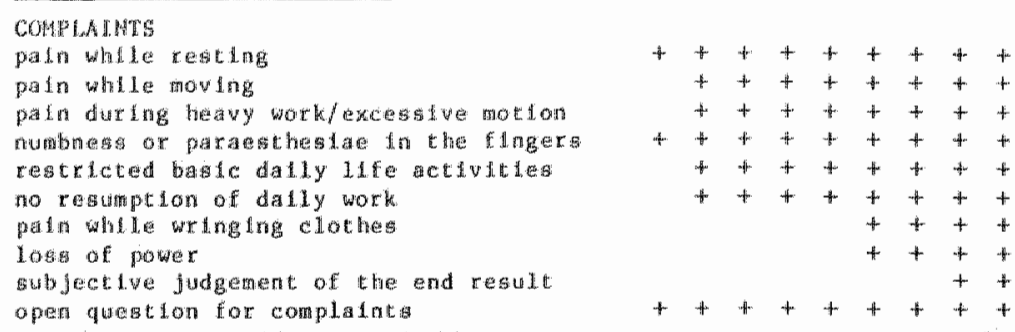

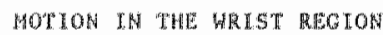

ditorad rexion

wolat flexton

radial devietion

unar dewlatom

auptnat ton

pronatom

\begin{tabular}{|c|c|c|c|c|}
\hline & + & + & + & \\
\hline+ & 4 & + & + & \\
\hline & tin & + & + & \\
\hline & + & + & + & \\
\hline & + & + & H. & \\
\hline & & & & \\
\hline
\end{tabular}

HOTOR FUHCTLONS OF THE OHAWD

grip power

makling a f $1 \mathrm{st}$

inger extension

oppostition

openting a door

welght $11 \mathrm{ft}$ ing

ploking up a pen

crumpling a plece of paper

lifting a cup and saticer

\begin{tabular}{|c|c|c|c|c|c|c|c|}
\hline \multirow{3}{*}{ 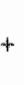 } & \multirow{3}{*}{ 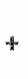 } & + & $+r$ & + & + & + & + \\
\hline & & + & + & $*$ & \# & + & + \\
\hline & & + & $n_{i}$ & + & + & + & + \\
\hline+ & + & of & i & + & 4 & + & + \\
\hline & & $f$ & * & + & + & + & + \\
\hline & & क्षم & w & $\phi$ & iㅏ & + & + \\
\hline & & $\neq$ & $\#$ & + & + & $t$ & + \\
\hline & & 4 & + & ar & + & + & $t$ \\
\hline & & + & $\downarrow$ & + & + & + & $f$ \\
\hline
\end{tabular}

SIGNS AND SYMPTQMS

swelling of had/flngers

abormat colour

skin atrophy/thypetes thes a / hyperhidrosig

hypodesthesia.

un Inar compresetion pan

restricted elbow axtenton

los of whoulder exturstion

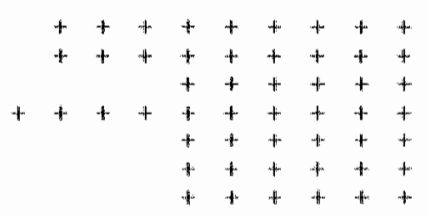

\section{Cosmintis}

cosmet lo appearance

$++$

\section{CONPLTCATLONS}

conplicatons from cant or brace

rediglocation

nerwe thojory

condon 1 indery

Sudack dystroplyy

lose of adto-ilinar Integricy

post crandate arthrtes

loss of mot lon

bupuytren ${ }^{2}$ ditsease

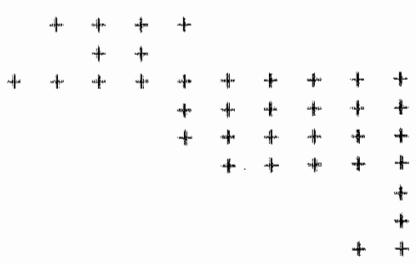

RADLOGAHHIG PARAMETLRS

wolar angle

cadla 1 angle

radial length

radial vidth

$\begin{array}{lllll}+ & +++ & + & + \\ + & +++ & + & + \\ + & +++t+ & + \\ + & +++ & + & +\end{array}$




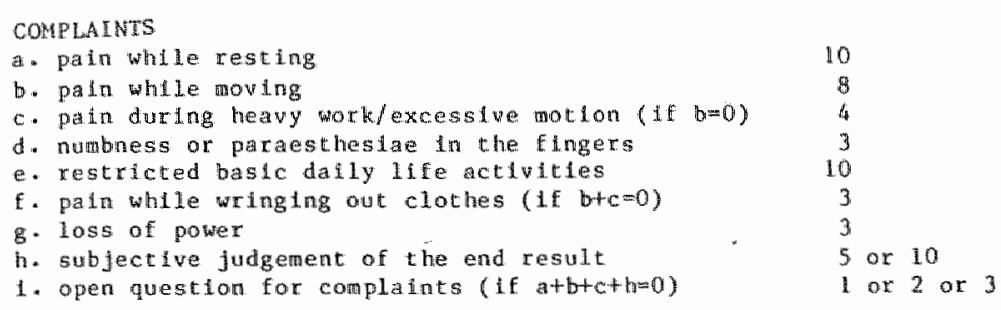

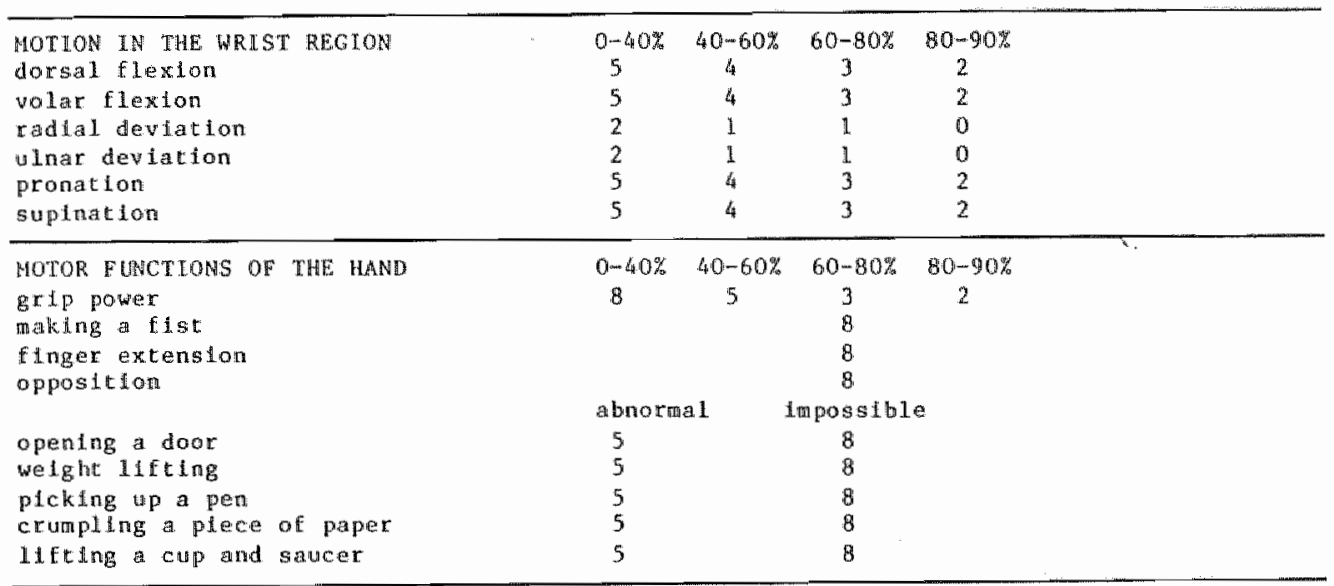

SIGNS AND SYMPTONS

swelling of hand/fingers 5

abnormal colour

skitn atrophy/hyperaesthes 1 a/ hyperhidrosis

ulnar compression pain

5
2
4
2

5.8 Score system for the functional result.

A score systen was designed to evaluate the functional result. With exception of the complications and radiographic parameters, al1 other groups of parameters listed in Table 5.9 were used. Complications and radiographic parameters were not considered in the score systen for the functional result as the effects of these two parameters groups on the functional result were assumed to be recorded by the included parameters. The parameters "hypoaesthesia" "restricted elbow extension" and "loss of shoulder excursion" were left out as these were never scored as abnormal. The penalty score assigned to parameters as shown in Table 5.12 was based on the guidelines of the Conmittee on Medical Rating of 
Phylical Impaiment (81) and on the ppinion of some prominent tramatologists in the vetherlands. The uninjured wrist served as the normal standard. Grip power of the dom lnant hand was assumed to be $110 \%$ of the nondominant side. "Subjective judgement of the end result" was scored 5 if the patient complained of inpaired function only during heavy work or extrardinary movement the score was 10 in case of impalred function durlng dally actluties or affected general way of life. "Open question for complaints" was the only paraneter to which the penalty scores were asslgned at the end of the study; 1 for complaints of sometimes prickling, ltching, cold/stiff fingers or aching during change in weather; 2 In case of blocking or clicking wrists, stiff joints, burning sensation, inabllity to use a vacum cleaner, carrying heavy objects or limitation of motion in one direction; the score was 3 for complaints of limitation of pulling, pushing, lifting heavy objects or limitation of wrist motion 1 in more than one direction. "Cosmetic appearance" scored 2 in case of a prominent ulnar" head, slight radial deviation, swelling or broadening of the wist; 3 for a comblnation of aforementioned findings and 5 when a pronounced radial deviation or dinnerfork deformity was found.

\subsection{Fracture classification}

Sarmiento's fracture classification (Figure 3.4) was used to determine the type of fracture, necessary for data analysis in this study. This classifiction system was selected as it is simple and includes fracture stabilty. Mintmally displaced fractures were classified as Type 1 or 3 . (Higure 5.13) This small modification was performed as it appeared that almost all "non-displaced fractures" still showed some slight displacement. The fracture characteristics "radio-ulnar joint involvement" (criterium: fracture towards ulnar head) and "ulnar styloid fracture" Erom Frykman's fracture classifications (Figure. 3.3) were also used in this study for analytic purposes.

\section{10 Statistical analysis}

A possible weakness in the design of the study is the patient allocation (Paragraph 5.2). After careful consideration it was cancluded that "pseudo-random" alternative day or subsequent patient-form assignement would be preferable to possible non compliance and uncontrollable use of a random assigrinent technique in a sometimes hectic 24-hours working casudity departenent with Erequent alternation of staff without conthuous administrative support of the study.

At the start of the study it appeared difficult to assess the sample size. Important information to apply power calculation was absent, like the minimally clinical important treatment difference, the level of response of the standard treatment and estimation of the variance. Experience with or numerical results of the specially designed score system for the functional result were not avallable. Numerical results of other score systens used in comparable studies were nonexistent, inadequate or non transposable. To guarantee $80 \%$ power for detecting a difference in mean response of half a standard deviation at the $5 \%$ significance level, a sample slze of approximately 60 patients in each group was chosen. Expecting large interpatient variability a difference in mean value of half a standard deviation between treatment groups was thought to be of possible clinical interest. 
Figure 5.13 Samiento"s fracture classification

Type 1
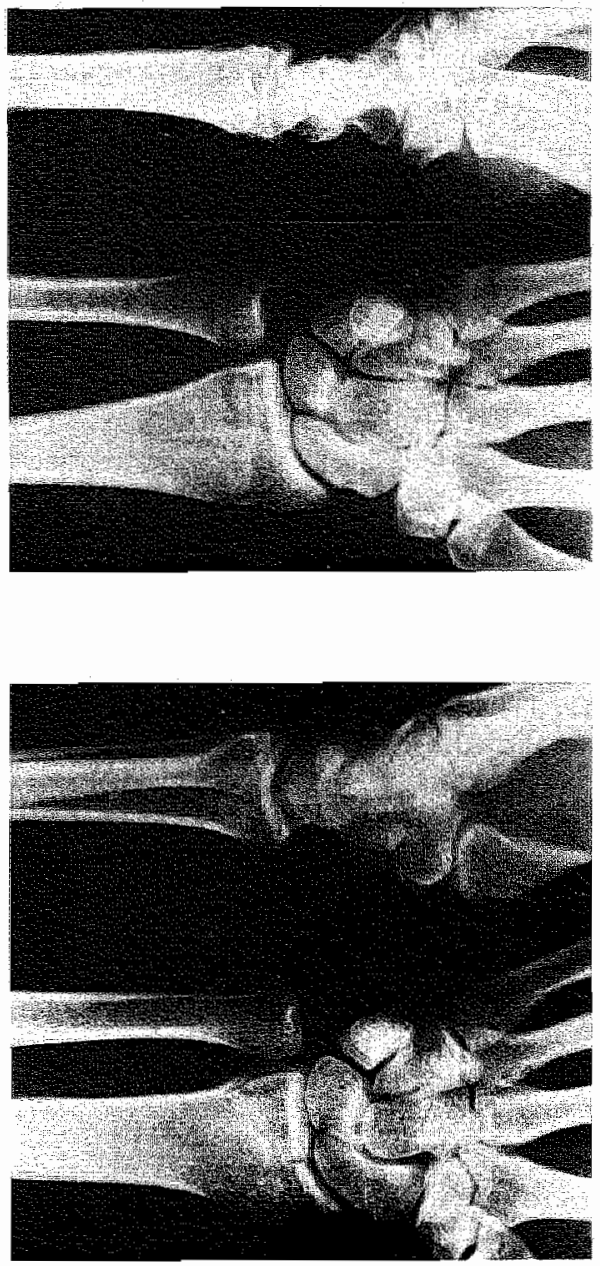

Type 3
Type 2
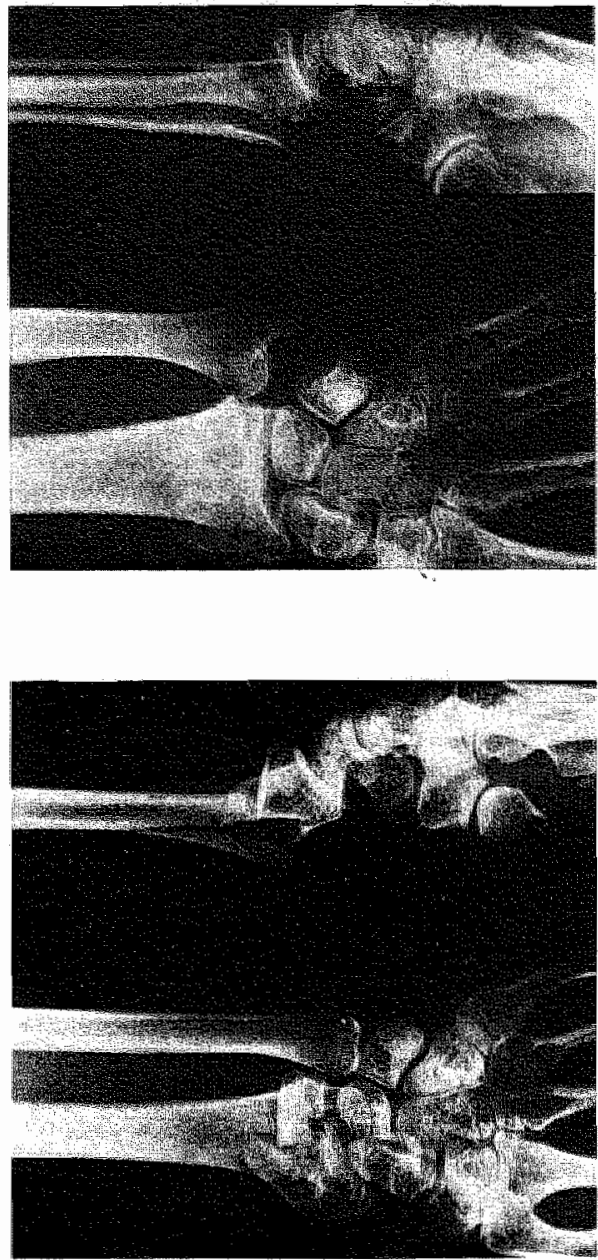

Type 4

In the study standard statistical techniques were used like analysis of variance, chi-square tests, t-tests and the Kruska11-Wa111s test. In the analyses of variance the results of the F-tests for thain effects are sometimes supplemented with t-tests for treatment and/or subgroup contrast to indicate the treatment groups or subgroups responsible for the difference indicated by a significant overall f-test. The significant level adopted for testing main effects was the $5 \%$ level. When testing contrasts a more stringent level was used to guard against the added risk of false-positive results induced by multiple hypotheses testing. As a visual aid to the reader, all p-values for main effects smaller than 5\% and all "significant" contrast test results were starred(*). Statistical analysis sometimes was done additionally as a check on 
cranstomed data to obtain better approximations to the assumptions necesary for use of the statistical techniques. When only trans formed data were analysed, the results are reported for the transformed date; 1til all other cages, the results are reported for the original non transformed data. Other statistical techniques used in this study were regresion analyes and techniques for the analysis of linear structural relation models based on the progran LISREL (93).

In order to assess the measurement error of some parameters, the wrists and hands of 10 healthy persons were subjected to measurements on flve subsequent occaslons. The results are listed in Table 5.14. The percentage of total varlance and the tolerance intervals for the absolute exror $\Delta=x-\mu$ are indicated. The tolerance interval encloses $90 \%$ of all potential absolute errors of measurement with $95 \%$ probability, which means that the difference between the actual value and at least $90 \%$ of the measurements will be less than the number indicated in the table, with a probability of $95 \%$. The results indicate that the measurement errors were not great. The measurement error of radiograph parameters was not calculated as the differences between various measurements of the same radiographs were very small. This indicates that an error of radiographic measurements hardly existed.

In the gtatistical analysis often less than $100 \%$ of the population of the concerned patient group was considered. This was due to the fact that in a few patients the uninjured wrist could not serve as the standard for comparission to calculate the functional result or anatomical result because of previous injuries. Other reasons were some lost radiagraps and the fact that not all patients attended all checkpoints. In most tables the number of subjects per cell is not indicated as this would have made these tables unnecessarily cluttered. The approximate number of subjects per cell however, can always be deduced from the preceding more elementary tables.

Table 5.14 Meanurement errors

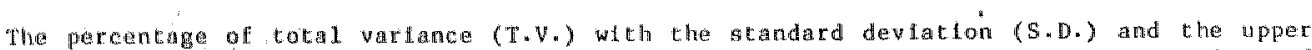

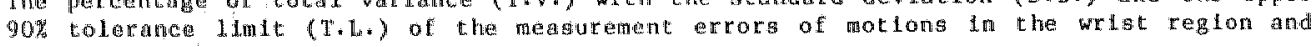
gir lip power.

\begin{tabular}{|c|c|c|c|}
\hline & $\mathrm{T} * \mathrm{~V}$. & $5 \cdot D$ & $\mathrm{~T} \cdot \mathrm{n} \cdot \mathrm{z}$ \\
\hline $\begin{array}{l}\text { doraal flexton } \\
\text { vollar flexton }\end{array}$ & $\begin{array}{r}3.8 \% \\
37.2 \%\end{array}$ & $\begin{array}{r}2 \% \\
13 \%\end{array}$ & $\begin{array}{l}4.09 \\
4.79\end{array}$ \\
\hline radial dev lat lon & $36 \cdot 18$ & $13 \%$ & 5.64 \\
\hline what dewitefon & $27.0 \%$ & $11 \%$ & 3.85 \\
\hline supunaton & $7.3 \%$ & $4 \%$ & 8.21 \\
\hline prometaton & $7.9 \%$ & 48 & 6.00 \\
\hline grtp power & $10.8 \%$ & $5 \%$ & 5.77 \\
\hline
\end{tabular}




\section{CHAPTER 6}

\section{PATIENT POPULATION}

248 Patients entered the clinical study. 52 patients were excluded or withdrawn (Table 6.1). The total number of participating patients was 196, predominantly elderly women (Table 6.2-6.4, Figure 6.5).

The right wrist was slightly more affected than the left (Table 6.6). The most frequent fracture type was the displaced fracture without radiocarpal joint involvement (Type 2), Followed by the displaced fracture with radio-carpal joint involvement (Type 4). Of the minimally displaced fractures, Type 1 was more frequent than Type 3 (Table 6.7). Ulnar styloid fracture as well as radio-ulnar involvement was encountered just under half of the cases (Table 6.8).

The initial displacement showed a wide range of values, which was more pronounced in displaced than in minimally displaced fractures (Table $6.9-6.12$ ). The avarage reduction did not result in a position close to the original anatomy (Table 6.13).

In the above mentioned data, no statistically significant differences between the three treatment groups were found with exception of the rightleft distribution and presence of ulnar styloid fracture (Table 6.6., $6.13)$.

The normal anatomy and normal motion in the wrist region as measured from the uninjured side, showed a large range of normal values (Table $6.14,6.15)$.

Table 6.1 Exclusion and whthdrati from participation

Reason for and number of excluded or whidraw cases.

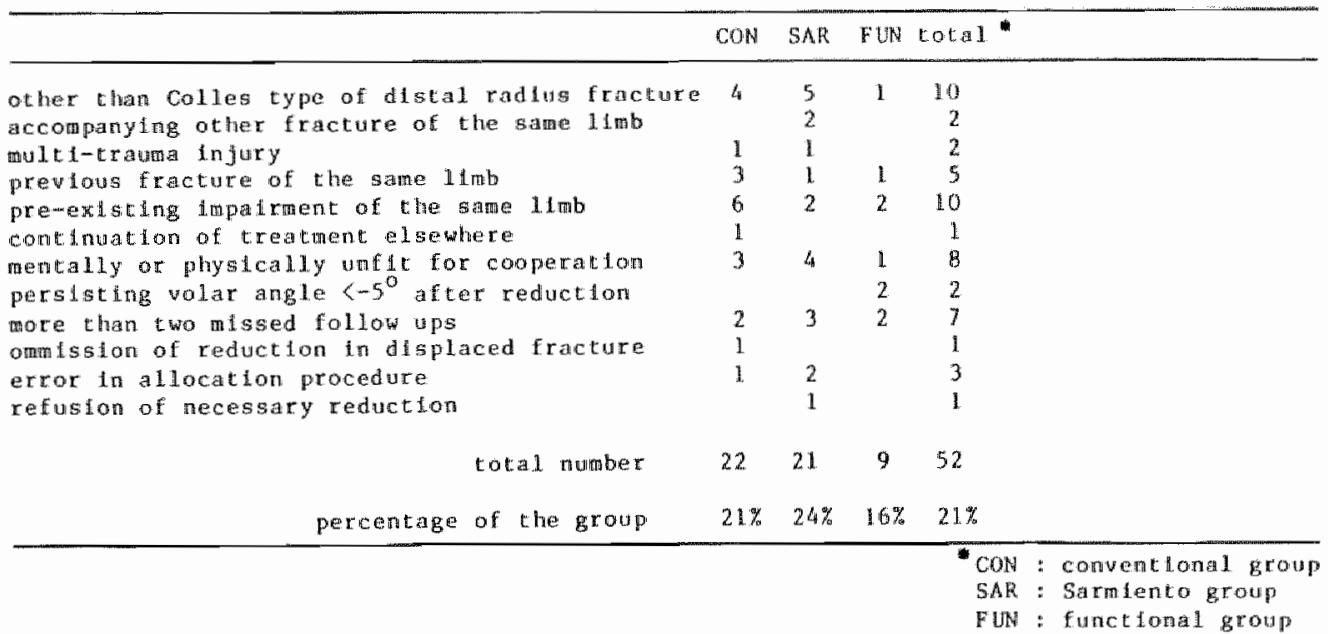




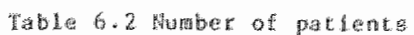

Hubar and percentage of pat

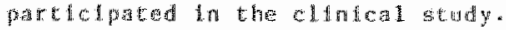

\begin{tabular}{|c|c|c|}
\hline & 唯 & $\%$ \\
\hline $\mathrm{COH}$ & 182 & 62 \\
\hline $5 A$ & 67 & $3 f^{2}$ \\
\hline Futs & 47 & 24 \\
\hline tot: 1 & 196 & 100 \\
\hline
\end{tabular}

Ta

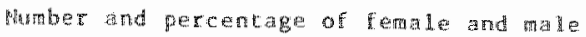
perat

\begin{tabular}{|c|c|c|c|c|}
\hline & \multicolumn{2}{|c|}{ errede } & \multicolumn{2}{|c|}{ ma } \\
\hline Con & 58 & $71 \%$ & 24 & $29 \%$ \\
\hline $\mathrm{S} \mathrm{A}$ & 58 & 87 in & 9 & $13 \%$ \\
\hline Etedy & 36 & $77 \%$ & 11 & $23 \%$ \\
\hline Lotal & 152 & $78 \%$ & 44 & $22 \%$ \\
\hline
\end{tabular}

Table 6.4 age distribution

Number and percentage of patients ln subsequent age lintervals in each group.

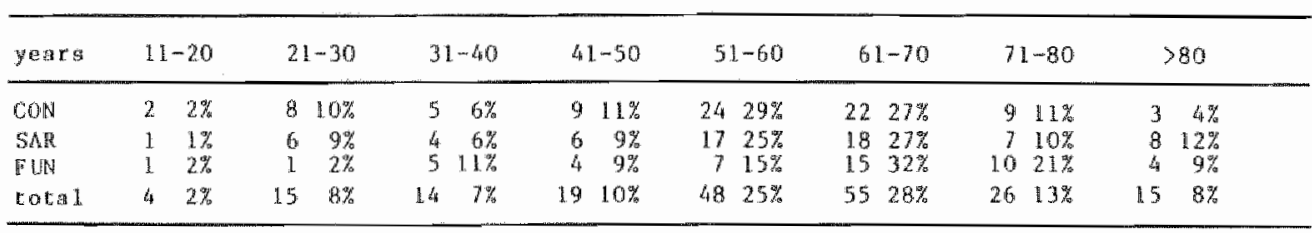

chlsquare test $p=0.51$

Figure 6.5 Age distribution for female and mat lat

Percentage of the cotal number of ferale and malo patong la subequent age latervila.

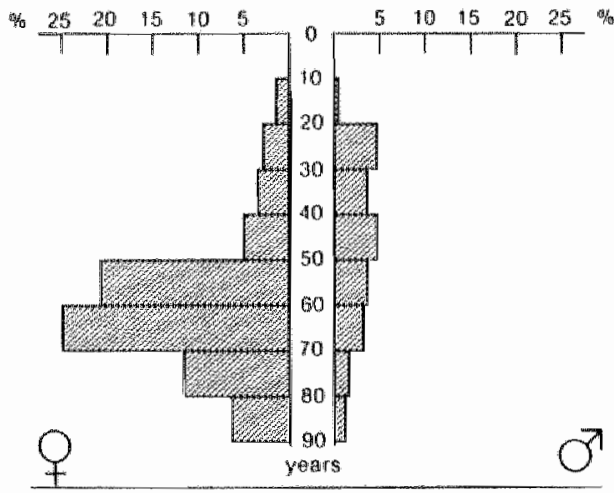

Table 6.6 Right-1eft distribution side of infury, number and percentage.

\begin{tabular}{lll}
\hline & rught & lelt \\
\hline CON & $4656 \%$ & $3644 \%$ \\
SAR & $4161 \%$ & $2639 \%$ \\
FUN & $1634 \%$ & $3166 \%$ \\
Lotal & $10353 \%$ & $934 \%$ \\
\hline
\end{tabular}

chisquare test $p=0.01 *$ 
table 6.7 Fracture type atstribution

Himber and percentage of patients in the four grotps of different tractute typas.

\begin{tabular}{|c|c|c|c|c|c|c|c|c|}
\hline & & $T L$ & & 12 & & 23 & & 14 \\
\hline $\mathrm{CHON}$ & 19 & $23 \%$ & 34 & $4 \perp x_{0}$ & 8 & $10 \%$ & 21 & $26 \%$ \\
\hline $5 \mathrm{AR}$ & 11 & $16 \%$ & 31 & 469 & क्षी & $6 \%$ & 21 & $31 \%$ \\
\hline Fut & 10 & $21 \%$ & 23 & $49 \%$ & 3 & $6 \%$ & 11. & $23 \%$ \\
\hline dotal & 40 & $20 \%$ & 88 & $45 \%$ & 15 & $8 \%$ & 53 & $2 \pi \%$ \\
\hline
\end{tabular}

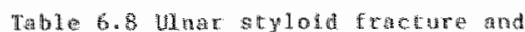

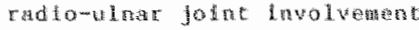

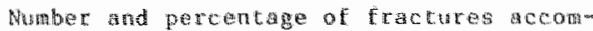

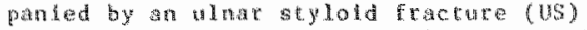

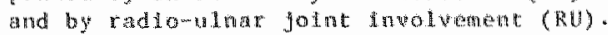

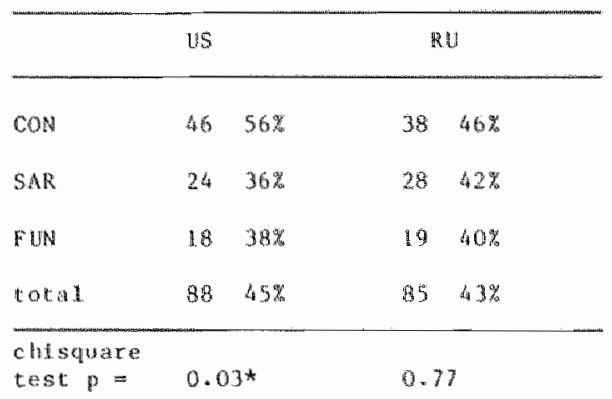

Table 6.9 Enitial volat angle difference

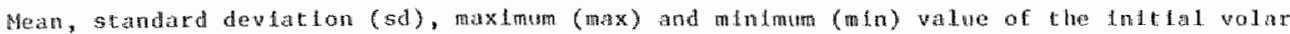
angle dfference (VI) of all fracture types (T1234) and of the four different types.

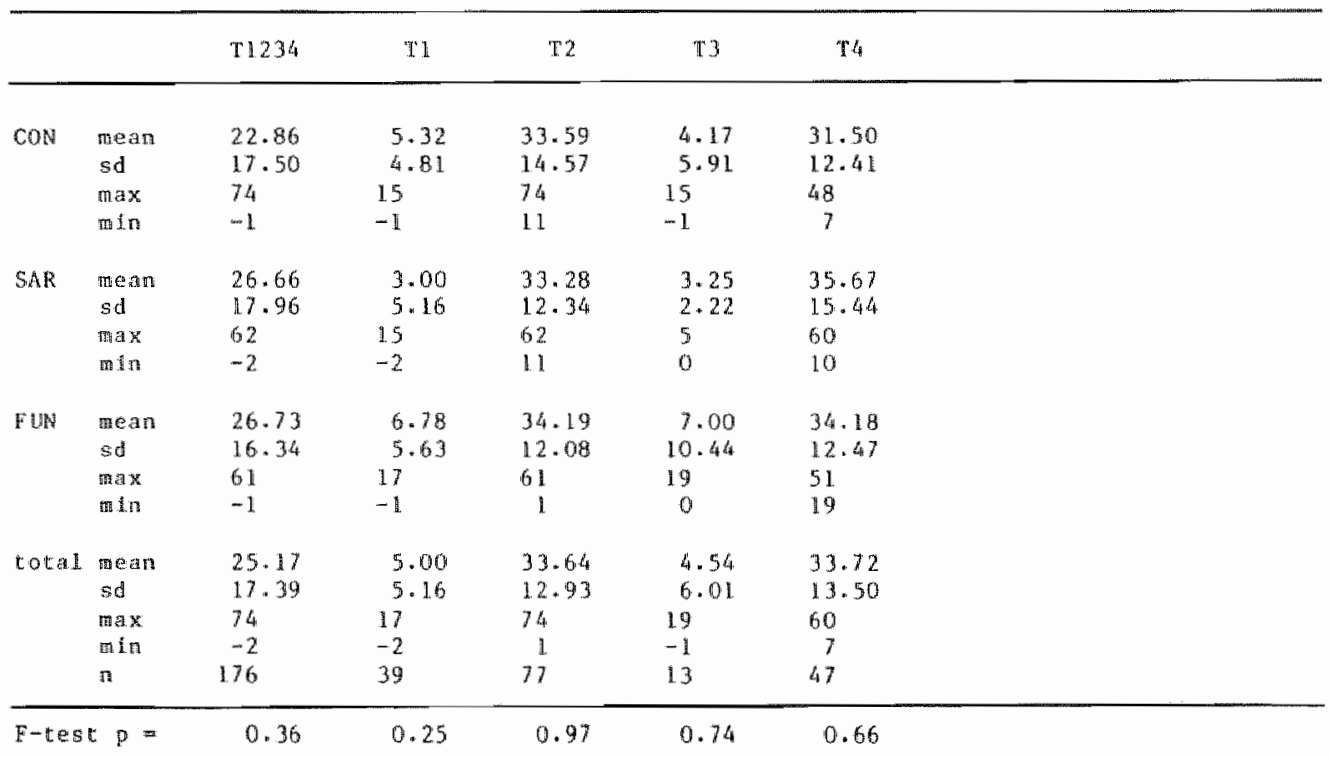


Jable 6.10 Intelal radal angla diference

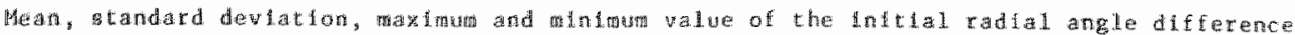
(21) of all fracture types and of the four different types.

\begin{tabular}{|c|c|c|c|c|c|c|}
\hline & & 141234 & $\mathrm{Tl}$ & $\mathrm{T} 2$ & 3 & $T 4$ \\
\hline \multirow[t]{4}{*}{$\operatorname{con}$} & mean & 6.10 & 0.42 & 8.27 & 3.33 & 10.12 \\
\hline & gid & 8.27 & 2.69 & 7.58 & 4.76 & 10.75 \\
\hline & 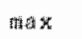 & 36 & 5 & 30 & 9 & 36 \\
\hline & In & -5 & -5 & -1 & -3 & -5 \\
\hline \multirow[t]{4}{*}{$S A R$} & 猢的越 & 6.97 & 1.55 & 8.59 & 0.25 & 9.29 \\
\hline & $8 d$ & 5.84 & $2 \cdot 98$ & 5.30 & 3.30 & 5.42 \\
\hline & 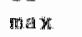 & 25 & 7 & 25 & 4 & 21 \\
\hline & $\operatorname{mon}$ & $-4 \frac{4}{44}$ & -2 & 3 & -4 & 2 \\
\hline \multirow[t]{4}{*}{ FUN } & mutery & 4.77 & -0.89 & 5.48 & 3.67 & 8.36 \\
\hline & 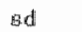 & 5.54 & $2 \cdot 15$ & $4 \cdot 31$ & 5.51 & 6.39 \\
\hline & max & 19 & 4 & 12 & 10 & 19 \\
\hline & แต 1 . & -3 & -3 & -3 & 0 & 0 \\
\hline \multirow[t]{5}{*}{$\operatorname{tot} 1$} & sean: & 6.07 & 0.44 & 7.62 & 2.46 & 9.38 \\
\hline & $\mathrm{sd}$ & 6.86 & 2.74 & 6.03 & 4.43 & 7.90 \\
\hline & M溷 $x$ & 36 & 7 & 30 & 10 & 36 \\
\hline & 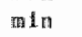 & -5 & --5 & -3 & -4 & -5 \\
\hline & $\mathrm{n}$ & 173 & 39 & 76 & 13 & 45 \\
\hline$F-\operatorname{ces}$ & t $p=$ & 0.27 & 0.14 & 0.16 & 0.52 & 0.85 \\
\hline
\end{tabular}

Table 6.11 Inttial radlal length difference

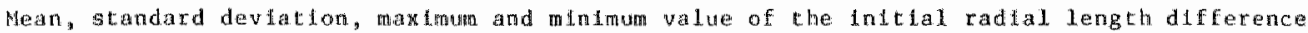
(Li) of all fracture rypes and of the four different types.

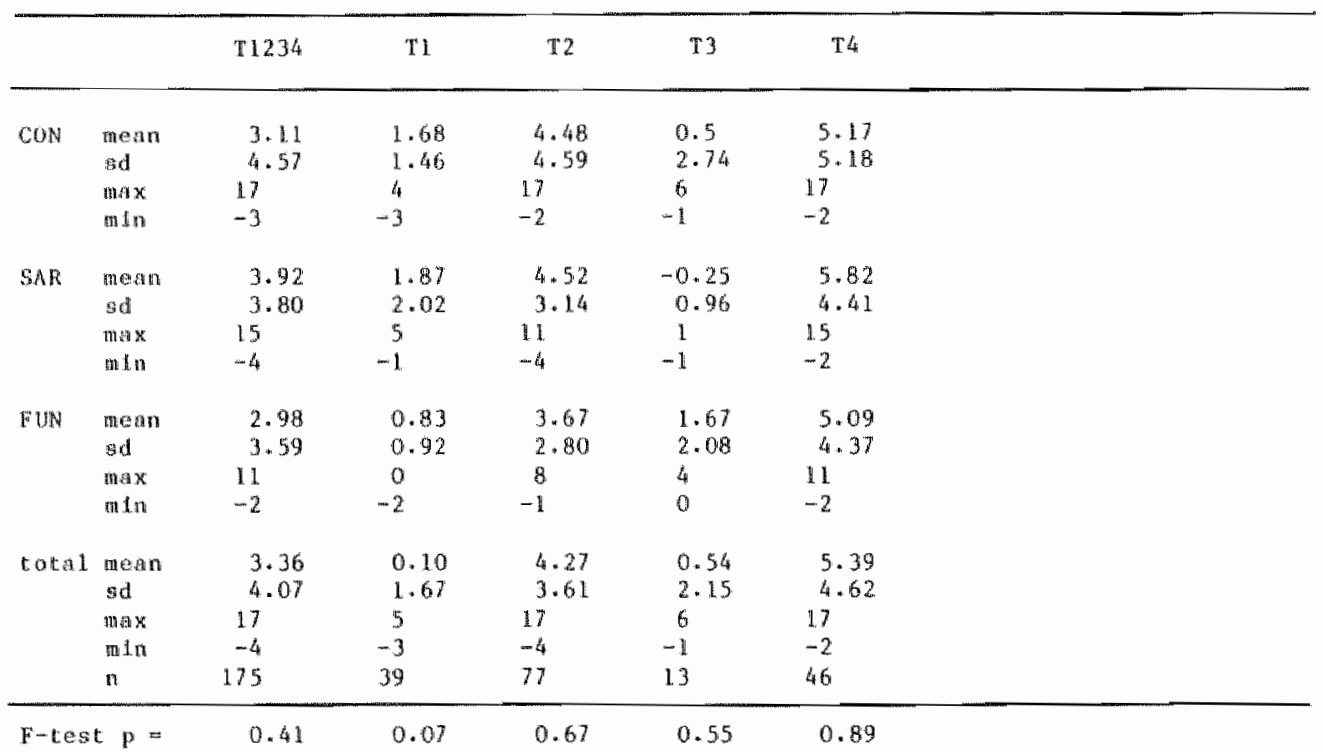


Table 6.12 andial radial shet

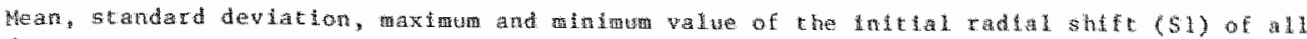
reacture types and of the four different types.

\begin{tabular}{|c|c|c|c|c|c|c|c|}
\hline & & T1234 & Tl & $\mathrm{T} 2$ & $\mathrm{~T} 3$ & $T 4$ & \\
\hline \multirow[t]{4}{*}{ cos } & mesn & -1.62 & -0.63 & -1.96 & -0.33 & -2.65 & \\
\hline & $s d$ & 2.14 & $1 \cdot 3.4$ & 1.48 & 1.63 & 3.14 & \\
\hline & $\operatorname{mat} x$ & 3 & 2 & 1 & 2 & 3 & \\
\hline & min & -9 & -3 & -6 & -3 & -9 & \\
\hline \multirow[t]{4}{*}{$S A R$} & tean & -1.98 & -0.64 & -2.29 & -0.25 & -2.77 & \\
\hline & $\mathrm{sd}$ & $2 \cdot 48$ & 1.4 .3 & $2 \cdot 30$ & 0.96 & 3.07 & \\
\hline & $\max$ & 5 & 1 & 2 & 1 & 5 & \\
\hline & 细量n & -8 & -3 & -8 & -1 & -6 & \\
\hline \multirow[t]{4}{*}{ FuN } & mean & -1.84 & -0.11 & -1.48 & -1.00 & -4.18 & \\
\hline & sd & 2.70 & $0+60$ & 2.91 & 1.00 & 2.18 & \\
\hline & $\max$ & 4 & 1 & 4 & 0 & -1 & \\
\hline & $\min$ & -11 & -1 & $-\mathbb{L}$ & -2 & -7 & \\
\hline \multirow[t]{5}{*}{ total } & mean & -1.80 & -0.51 & -1.95 & -0.46 & -3.07 & $x$ \\
\hline & $\mathrm{sd}$ & 2.41 & 1.23 & 2.25 & 1.27 & 2.92 & \\
\hline & $\max$ & 5 & 2 & 4 & 2 & 5 & \\
\hline & $n+n$ & -11 & -3 & -11 & -3 & -9 & \\
\hline & n. & 172 & 39 & 75 & 13 & 45 & \\
\hline
\end{tabular}

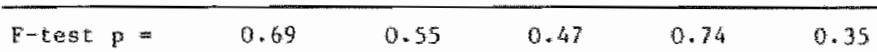

table 6.13 Qunal1ty of reduction

Wean, standard deviation, maxtmum and mofmum value of the wolm argle, radial angle and radial length diference (V2, $\mathrm{k} 2, \mathrm{L2}$ ) and radial shits (S2) after reduction, for fracture type 2 and 4 .

\begin{tabular}{|c|c|c|c|c|c|}
\hline & & $\sqrt{2}$ & 2 & $\mathrm{~L} 2$ & 52 \\
\hline \multirow[t]{5}{*}{$\mathrm{CON}$} & mean & 8.29 & 3.36 & $1+31$ & 1.81 \\
\hline & $\mathrm{sid}$ & 6.25 & 3.77 & $2 \cdot 3 \cdot 4$ & 1.85 \\
\hline & Fax & 25 & 11 & 9 & 6 \\
\hline & 踏 & -8 & -6 & -4 & -2 \\
\hline & $n$ & 49 & 48 & 48 & 48 \\
\hline \multirow[t]{5}{*}{ SAR } & mean & 5.80 & 4.70 & 1.41 & 1.47 \\
\hline & $\mathrm{sd}$ & 6.83 & 5.24 & 3.05 & 2.57 \\
\hline & $\max$ & 19 & 23 & 11 & 6 \\
\hline & $\operatorname{lin}$ & -11 & -3 & -6 & $=9$ \\
\hline & $\mathrm{n}$ & 49 & 49 & 49 & 49 \\
\hline \multirow[t]{5}{*}{ Fun } & mean & 7.52 & 4.84 & 1.52 & $2 \cdot 13$ \\
\hline & sd & 6.62 & 3.46 & 2.78 & 2.09 \\
\hline & 世的 & 22 & 13 & $B$ & 6 \\
\hline & min & -3 & -1 & -4 & -2 \\
\hline & $n$ & 31 & 31 & 31 & 31 \\
\hline \multirow[t]{5}{*}{ total } & ตำ & 7.14 & $4 \cdot 25$ & 1.40 & $-1.7 \%$ \\
\hline & $5 \mathrm{~d}$ & 6.61 & 4.32 & 2.72 & 2.20 \\
\hline & mas? & 25 & 23 & 11 & 6 \\
\hline & $\min$ & -11 & -6 & -6 & -9 \\
\hline & $n$ & 129 & 124 & 128 & 128 \\
\hline
\end{tabular}

$p-\operatorname{test} p=0.21 \quad 0.24 \quad 0.95 \quad 0.44$




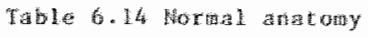

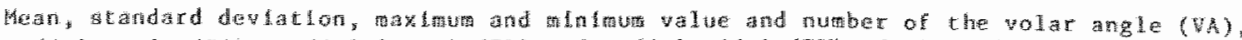

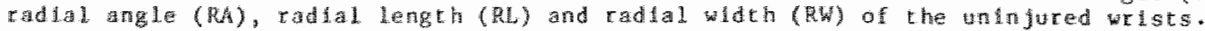

\begin{tabular}{|c|c|c|c|c|}
\hline & $V A$ & $\mathrm{R} A$ & $\mathrm{RL}$ & min \\
\hline 触 & $11 . \mathbb{S}$ & 26.21 & 11.48 & 16.97 \\
\hline gad & 3.83 & 3.08 & 2.40 & 2.17 \\
\hline 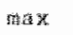 & 20 & 34 & 19 & 24 \\
\hline min & -1 & $\mathbb{1 B}$ & 6 & 11 \\
\hline n & 179 & 179 & 179 & $1 / 9$ \\
\hline
\end{tabular}

Table 6.15 Nornal mothon in the wrigt reglom

Han, gandard devlation, maxtrum and mintmus value and number of dorsal flexton (DF), wolar flexton (VF), radal deviation (ED), wlar devtatlon (UD), pronation (PRO) and suphation (SUP) of the uninfured side.

\begin{tabular}{|c|c|c|c|c|c|c|}
\hline & $\mathrm{DF}$ & $\mathrm{VE}$ & $\mathrm{RD}$ & wat & PRO & SUP \\
\hline ming an & 66.110 & 65.20 & 24.65 & 32.37 & 79.17 & 114.42 \\
\hline gd & 8.43 & 8.95 & 5.07 & 5.83 & 16.65 & 13.21 \\
\hline $\max$ & 95 & 88 & 40 & 50 & 120 & 140 \\
\hline nn I|n & 45 & 35 & 10 & 18 & 40 & 40 \\
\hline$n$ & 184 & 184 & 184 & 184 & 184 & 184 \\
\hline
\end{tabular}




\section{CHAPTER 7}

\section{RESULTS}

As a consequence of the formulated hypotheses (Chapter 4 ) outcome of the functional recovery, functional end results and complications in the three treatment groups are presented, as well as the anatomical end results and the relationship between the anatomical and functional end result.

\subsection{Functional recovery}

The speed of the functional recovery was assessed by the rapidity that the functional result score decreased (i.e. the functional result improved) between the subsequent check points during one year. In order to compare the same parameters at each check point (Table 5.9) the following parameters were excluded in the determination of the functional recovery:

- pain while wringing clothes

- loss of power

- subjective judgement of end results

- cosmetic appearance

During one year follow-up, the functional result score of the majorlty of the patients decreased rapidly initially, later on more gradually to reach low values (Figure 7.1 ). At all checkpoints the functional group obtained a lower mean score than the other two treatment groups (Figure 7.2). However, only in the beginning at werk 4 was this difference statistically significant $(\mathrm{p}=0.02$, Table 7.3$)$, due to the difference between the functional and conventional group (contrast $p=0.01$ ). "The contribution of the four involved parameter groups (Table 5.12) to the total score was calculated separately so as to find the most influential factors in the difference of the score at week 4 . The "motion in the wrist region" and the "motor functions of the hand" turned out to be mainly responsible for the difference. The "complaints" and "signe and symptoms" did not contribute significantly to the difference (Table 7.4).

To investigate whether the difference in functional recovery between the treatment groups depended on the fracture type, the functional result score at week 4 was calculated for each fracture type separately. Sarmiento's fracture Type 1 and 3 turned out to be not significantly different with respect to the functional recovery as shown by a two way analysis of variance (Addendum 4). Regarding the functional recovery fracture Type 1 and 3 are therefore considered to be the same type of fracture (T 1/3). Fracture Type $1 / 3$ obtained in the functional group a significantly lower mean functional result score at week 4 than in the conventional group. The mean score of fracture Type 2 was in the functlonal and in the Samiento group lower than in the conventional group. No significant difference between the groups was found in fracture Type 4 (Table 7.5). 
7.2. Finctional end result

The functional end result was determined by the functional result score one year after the trama. In contrast with the functional recovery (Paragraph 7.1) all parameters of the functional result score were considered in the calculation of the functional end result. No statistically gignificant differences were found between the treatment groups (Table $7.6)$.

The functional end result was also calculated for the different fracture types separately. Analogous to the functional recovery fracture Type 1 and 3 were regarded to be the same type of fracture ( $T$ 1/3) with respect to the functional end result, as a two way analysis of variance did not reveal a significant difference between these types (Addendum 5). No significant difference between the treatment groups was found for the three distinct fracture types separately (Table 7.7 ).

In Chapter 6 imbalances between the treatment groups at baseline were presented (Left-right distribution and presence of ulnar styloid fracture). As patients were not randomly allocated to the treatment groups it was Imperative to adjust each important treatment comparison for baseline differences. To correct for these baseline differences (possible confounding varlables) and at the same time to assess the prognostic value of the varlous recorded patient characteristics and early responses to the initial treatnent, regression analysis was performed. In the regression analysis the functional end result was modelled as a linear function of possible prognostic and confounding variables and their interactions. The variables explored in this regression analysis were personal data (sex, age, profession, dominant hand), fracture type, fracture characteristics (ulnar styloid fracture, radio-ulnar joint involvement), initial displacement (Initial volar angle difference (V1), radial angle difference (RI), radial length difference (L1), radial shift (S1)), quality of reduction (post-reduction volar angle difference (V2), radial angle difference (R2), radial length difference (L2), radial shift (S2)), method of treatment (CON, SAR, FUN) and anamnestic and objective parameters scored during the first two weeks (e.g. pain, sweliing, opposition). After statistical exploration, some variables were left out because these appeared to be not important for the functional end result. The vartables represented in the final regression analysis are listed in Table 7.8. The predictive value of the regression analysis is Low as indicated by a low R-square value of $36 \%$, which means that only $36 \%$ of the varlation in the functional end result score could be explained by the prognostic variables. No clinically useful subgroups could be composed based on prognostic variables, that would obtain better functional end results wth one method of treatment than with the other two methods. The method of treatment, even after correcting for the influence of other prognostic variables, definttely has no significant effect on the functional end result. The overall most important prognostic factors of the functional end result seem to be the initial volar angle difference (V1) $(p=0.00)$ and to a lesser extend the occurrence of an ulnar styloid fracture $(p=0.06)$. When corrected for the influence of other prognostic variables the type of fracture appears not to be a significant prognostic variable. Treatment in the Sarniento group seems unfavourable for patients with radio-ulnar joint involvement, but beneficial for patients with an ulnar styloid fracture. Due to the low $R$-square value, this conclusion probably has no clinical significance. 


\section{3 Complications}

As indicated in Table 7.9 , the number of cases in each group of complications separately was too low for statistical analysis. Therefore a 11 complications were added in each treatment group. No statistically significant difference was found in the incidence of all complications between the three treatment groups (Table 7.10). After correcting for the influence of possible confounding variables (llke age, sex and radiominar joint involvement) by means of regression analysis, still no significant difference was found.

\section{- Complications due to cast or brace}

Pressure sores or abrasions were found on nine occasions, a shifted brace was seen two times, plaster allergy was encountered once.

- Redislocation needing rereposition

Rerepasition was done thirteen times at week 1 and four times at week 2 . In nine cases the fracture type was 2 , in eight cases the type was 4.

- Nerve injury

Median nerve compression (MNC) was diagnosed by EMG-study in 16 cases within 3 months after the injury. In 10 cases operative decompression resulted in relief of complaints. The other 6 cases were not operated on due to spontaneous improvement. The fracture type distribution was six times Type 4, six times Type 2, four times Type 1. None of these patients underwent a second reduction during the initial management, in one case rereposition at week $l$ was performed. One year after the trauma, none of the 16 patients complained of MNC symptoms. In 8 out of the sixteen cases, EMG-signs of mild MNC were also found at the uninjured wrist, whout causing complaints. Although the mean functional end result score in cases with MNC was higher than in all other cases, this difference was not statistically significant (Table 7.11).

- Tendon injury

Spontaneous rupture of the extensor pollicis longus tendon was seen two times (fracture Type 1 and 4 ). One patient underwent an extensor indicis proprius tendon transfer, the other refused operation. Five times stenosing tendovaginitis was seen within half a year after the trauma. Two cases were successfully treated with corticosteroid injection, in the other three cases this treatment falled and operative release was perfor med.

- Sudeck dystrophy

In seven cases Sudeck dystrophy (SD) stage 1 and in 7 cases stage 2 wab found. Eight times the fracture type was 2 , six times the type was 4. Two out of 14 cases underwent a second reposition during the indtal thanagenent. The mean functional end result score in all cases of SD was significantly higher than in all other cases ( $\mathrm{p}=0.02$, Table 7.12$)$, mainIy due to the functional end result in cases with SD stage 2.

- Loss of radio-ulnar integrity (RUI) was diagmased in 25 cases; three times in fracture Type 1, thirteen times in fracture Type 2 and nine times in fracture Type 4. Radio-ulnar joint involvement and ulnar stylold fracture were associated with loss of RUI in 15 (60\%) and 14 (56\%) cases. Three patients underwent a Darrach procedure during the second half of the first year, resulting in improvement of the complatnts. The mean functional end result score of patients with loss of RUI was significantly higher than in all other cases $(p=0.00$, Table 7.13$)$.

- Post-traumatic arthritis

One year after the trauma, post-traumatic arthritis (PA) was dagnosed in 31 cases, four times in fracture Type 1 , ten times in fracture Type 
2, chree thes in fracture Type 3 and fourteen times in fracture Type 4. Radio-ular jolnt involvenent and unar stylold fracture were associated Wth $\mathrm{EA}$ in $18(58 \%)$ and $13(42 \%)$ cases. The mean final volar angle difEerence (V3), radial angle difference (R3), radial length difference (L3) and radlal shift (S3) was respectively $9.30,5.93,3.93,3.12$, which 1 s not significantly different from the mean values of all patents (Table 7.15). The mean functional end result score of cases with PA was Bigniflcantly higher then of all other cases $(p=0.04$, Table 7.14).

- Loss of motion was found in twenty-one cases.

- Dupuytren" s disease was seen five times, accurring within half a year after the trauna. No contractures were found diring one year.

\section{4 Anatomical end result}

The anatonlcal end result was deternined by the final volar angle difference, radial angle difference, radial length difference and radial shift, one year after the trauma (V3, R3, L3 and S3).

The anatonleal end result in the functional group showed a significantly greatex mean final radial angle difference and final radial length diffem rence than the conventional group (contrasts $p=0.01, p=0.00$, Table 7.15), while the Samitento group showed a silgnificantly higher mean radial angle difference than the conventional group (contrast $p=0.04$ ).

With respect to the anatomical end result, fracture Type 1 and 3 were regarded to be the same type of minimally displaced fractures ( $\mathrm{T}$ 1/3); fracture Type 2 and 4 were regareded to be the same type of displaced fractures $(\mathrm{r} 2 / 4)$, as a two way analysis of variance did not reveal statistically significant differences between fracture Type 1 and 3 and between fracture Type 2 and 4 (Addendum 6). As shown in Table 7.16 and 7.17, the difference in anatomical end result between the groups is due to differences in displaced fractures ( $T$ 2/4). No significant difference was seen in minimally displaced fractures ( $T 1 / 3$ ).

Analogous to the functional end result, a regression analysis was performed for each of the four anatomical end result parameters (V3, R.3, L3 and 53). Again this was needed to correct for imbalances between the treatment groups at baseline and to assess the prognostic value of the varlous variables recorded at the beginning of the study.

The four regression analyses with dependent varlables final volar angle difference, radial angle difference, radial length difference and radial shitt, are listed in lable 7.18 to 7.21. The predictive value of the regression analyses however, 1 s rather low as shown by low R-square values, indlcating high percentages of unexplained variation. Due to this, no clinical useful subgroups could be composed on prognostic variables that would obtain better anatomical end results with one method of treatment than with the other two. The mean final radial angle diference and radial length difference in the functional group was still signiflcantly higher after correcting for influences of other variables than in the conventional group ( $p=0.00$, Table 7.19. $p=0.00$, Table 7.20). The most important prognostic variables of the anatomical end result were the initlal displacement parameters. Age and the fracture characteristics radioulnar joint involvement and ulnar styloid fracture also seemed to have prognostic value. The fracture type had no prognostic value for the anatomical end result. - 
7.5 Relation between anatonical end result and functional and result.

The correlation between anatomical end result and functional end result was assessed by plotting the anatomical end results (V3, R3, L3 and $\$ 3$ ) against the corresponding functional end result (FR). In a scatter diagram points clustering around a straight line and a correlation coefficient close to $\mathbb{1}$. 0 would indicate $a$ high linear correlation. In this study, no linear correlation was found as shown in Figure 7.22 . In subgroups of younger patients ( $\leqslant 50$ years) some higher correlation caefficient between anatomical and functional end result were found than in the whole population (Table 7.23 ). In the calculation of aforenentioned so called "crude correlations" no influence of other factors on the anatomical or functional end result was considered. As mentioned in Paragraph 3.13, a crude correlation coefficlent is not a proper indication of a causal relationship. To investigate the causal relationship between anatonical and functional end result, the relations between "cause" and "effect" variables were formulated and analysed in a system of structural equations by means of "analysis of linear structural relationships". In this anallysis, the "response" varlables: "anatonical end result" (V3, R3, L 3, S3) and "functional end result" (FR), were linked to the "explanatory" vaxiables: "methods of treatment" (CON, SAR, FUN), "fracture types" (T1, T2, T3, T4), "fracture characteristics" (RU, US), "age", "initial displacenent" (V1, RI, L1, SI), and were linked to the "intermediary" variables: "major complications" (CONPL: Sudeck dystrophy, median nerve compression, loss of radio-ulnar integrity, posttraumatic arthritis) and "anamestic parameters" (ANAM: pain, numbness feeling, restricted daily life activities in the first two weeks), in a system of linear equations. The results are presented in two very condensed path-diagrams (Figure 7.24), one for patients above and one for patients below 50 years of age. These represent the essential information about the most interesting and relevant causal chains. The origlnal path-diagrams, in which all above mentioned variables were linked, were too complicated for simple graphical expression. Only between the initial displacement, major complications, the anatomical end result and the functional end result relevant causal chains were found. All the other variables including the method of treatment, the fracture type and the age of the patient did not contribute to important or relevant causal chains. The arrows in the two presented path-diagrams indicate relations in the time and possible causal effects. Biological and clinical plausibility however, determines if these relations indeed can be regarded as causal. The corresponding values in the path-diagrams indicate "partial-correlations". (A partial correlation means a correlation between two variables that is corrected for the influence of other variables). Behind each partial-correlation the corresponding crude correlation is indicated in parentheses, frequently these two differed substantially. The partial correlations ( $\mathrm{PC}^{\mathrm{B}} \mathrm{S}$ ) between the anatomical end result and the functional end result were relatively low, compared to the other PC's (Figure 7.24). The PC between complications and functional end result was much higher in the younger group than in the older $(0.56,0.15)$. In the younger group, some high PC's were found between the initial displacement and complications $(0.61)$, and between the initial displacenent and the functional end result (0.70). In the older group one anatomical end result parameter (V3) showed relatively the highest $\mathrm{PC}$ towards the functional end result (0.31); in absolute sense however, this is still a very low partial correlation. 
The most inportant factor influencing the functional end result in both the younger and older patients was the initial displacement. This factor had both a drect 1 influence on the Eunctional end result and an indirect influence wa "complications" and "anatomical end result". In the younger group the intemediary influence of complications on the functional end result was relatively large. The initial displacement also seened the most fmportant causal factor detemining the anatomical end result.

\subsection{Conclusions}

The functional recovery in the functional group tended to be quicker than in the other two groups. In the beginning, at week 4 , this was statistically significant due to better motions in the wrist region and better notor functions of the hand. The early functional recovery was significanty faster in the functional group for fracture type 1,2 and 3 and in the Samiento group for Eracture Type 2. In Eracture Type 4, no difference in early functional recovery was found.

The Eunctional end result was not significantly different in the three treatment groups. Prognostic factors of the functional end result were the initial displacement and accurrence of ulnar styloid fracture. The most limportant causal factors influencing the functional end result were the initial displacenent and occurrence of complications. The method of treatment, the fracture type and the age of the patient were not important .

The incidence of complications was also not significantly different in the three treatment groups. Sudeck dystrophy, loss of radio-ulnar integrity and post-traumatic arthritis, were significantly associated with poor functional and results, while there was a trend in median nerve compression. Second reduction, rereduction, type of fracture, radio-ulnar joint involvement, and ulnar styloid fracture seemed to have no important relation with median nerve compression, Sudeck dystrophy or Loss of radio-ulnar integrity. The fracture characteristics radio-ulnar joint involvement and ulnar stylold fracture were not highly associated with loss of radio-ulnar joint integrity or post-traumatic arthritis. The anatonical end result seemed not an important prognostic factor for developrent of post-trauatic atthritis within one year after the trauwa. Whe occurrence of a colles fracture might have altered subcinical median nerve conpression lato clinically manifest nerve compression.

Whe anatomical end result wa in the functional group inferior compared to the conventiona group, due to differences in displaced fractures. Mnually displaced frackures showed no signiticant difference between the treatment groups. Prognostic factors for the anatonical end result were the initial displacement, radio-ulnar joint involvement, ulnar styloid fracture, age and method of treatment. "The most important causal factor influencing the anatomical end result was the initial displacement.

The causal relationship between anatomical and functional end result seened very weak. (This is underlined by the significantly different anatomical end results in conbination with equal functional end results in two methods of treatment.) The crude correlations were inreliable indicatons for the causal relationship.

In the analyses rather high percentages of unexplained variance were 
found. As the measurenent errors were not great (Table 5.14), it is most likely that this was arnly due to extensive interpatient variability.

Samiento's fracture Type 1 and 3 , as modified in this study, appeared to be the same type of fracture.

Figure 7.1 Functional recowery

Box plots of the functional result score

(FR) for all tases at the subsequent checkpolnts. The box plot tnd loates the upper and lower linits, the tuterquactle ranges and the medlan walue.

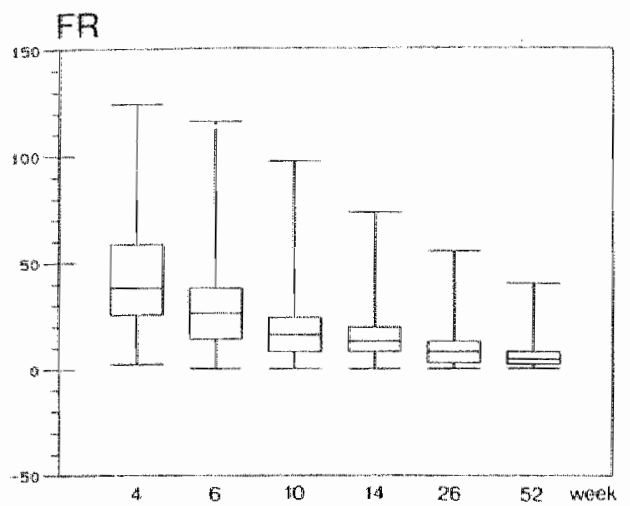

rigure 7.2 Functiond tecovery for eath group

Mean value of the functional result score (FR) at the subseapuent checkpoints for each treacment group.

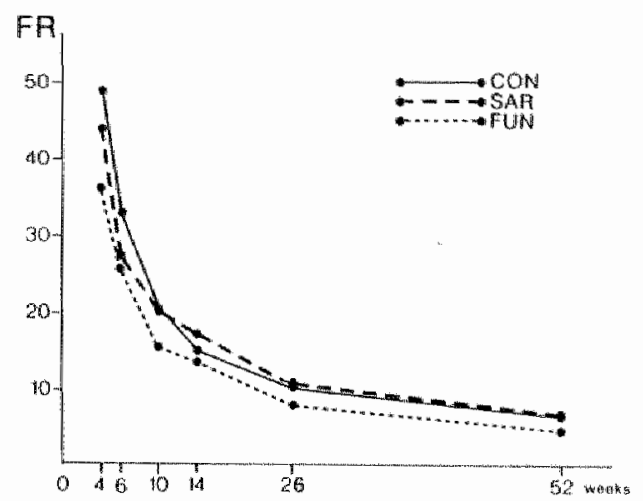

Table 7.3 functional results per treatment group

Mean, scandard devtation, maximum and mintmum value and number of the functional result score (FR) at the subsegatent checkpolnts for each group for all fractute types.

\begin{tabular}{|c|c|c|c|c|c|c|c|}
\hline & week & 4 & 6 & 10 & 1.4 & 26 & 52 \\
\hline \multirow[t]{5}{*}{ CON } & mean & 49.14 & 33.24 & 20.82 & $15+52$ & 10.01 & 6.33 \\
\hline & and & $27 \cdot 18$ & 23.73 & 18.66 & 12.51 & 9.91 & 5.92 \\
\hline & wax & 120 & 111 & 97 & 62 & 55 & 40 \\
\hline & min & 5 & 1 & 2 & 0 & 0 & 0 \\
\hline & ก & 73 & 72 & $7 / 4$ & 73 & 74 & 73 \\
\hline \multirow[t]{5}{*}{$S A R$} & 地世an & 43.92 & 27.48 & 20.17 & 17.60 & 10.48 & 6.60 \\
\hline & $\mathrm{sd}$ & 23.77 & 18.71 & 17.06 & 1.4 .76 & 9.63 & 6.83 \\
\hline & 禹虾 & 124 & 116 & 89 & 73 & 53 & 35 \\
\hline & min & 12 & 6 & 0 & 0 & 0 & 0 \\
\hline & $\mathrm{n}$ & 65 & 60 & 64 & 63 & 61 & 58 \\
\hline \multirow[t]{5}{*}{ FUN } & mean & 36.52 & 25.74 & 15.72 & 13.82 & 7.83 & 4.56 \\
\hline & $\operatorname{sid}$ & 24.51 & 20.14 & 12.64 & 9.70 & 5.76 & 4.38 \\
\hline & $\max$ & 106 & 109 & 78 & 46 & 26 & 22 \\
\hline & $\operatorname{tin}$ & 2 & 0 & 0 & 0 & 0 & 0 \\
\hline & $\mathbf{n}$ & 47 & 46 & 46 & 45 & 42 & 43 \\
\hline \multicolumn{2}{|c|}{$\begin{array}{l}F-\operatorname{teg} \mathrm{p}= \\
\mathrm{t}-\mathrm{tegt} \text { for } \\
\text { conteasts }\end{array}$} & $0.02^{*}$ & $0 . \mathbb{1} 1$ & 0.28 & 0.78 & 0.53 & 0.20 \\
\hline $\mathrm{C}-\mathrm{S}$ & $p=$ & 0.26 & & & & & \\
\hline$C-F$ & $\mathrm{p}$ & 0.01 & & & & & \\
\hline$S-F$ & $\mathrm{p}=$ & 0.08 & & & & & \\
\hline
\end{tabular}


Trible 7.4 seore of paraneder growp

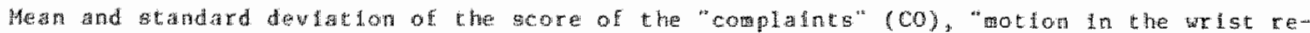

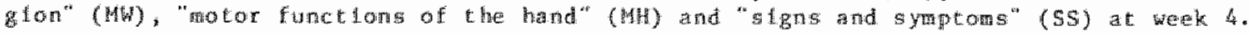

\begin{tabular}{|c|c|c|c|c|}
\hline & $\mathrm{CO}$ & MW & Wh & 55 \\
\hline $\begin{array}{c}\text { CoN nean } \\
\text { asd }\end{array}$ & $\begin{array}{l}6.23 \\
6.13\end{array}$ & $\begin{array}{r}14.69 \\
3.32\end{array}$ & $\begin{array}{l}25.97 \\
18.77\end{array}$ & $\begin{array}{l}3.34 \\
3.65\end{array}$ \\
\hline $\begin{array}{c}\text { SAR wean } \\
\text { ad }\end{array}$ & $\begin{array}{l}6.06 \\
6.16\end{array}$ & $\begin{array}{r}14.80 \\
4.01\end{array}$ & $\begin{array}{l}20.21 \\
16.09\end{array}$ & $\begin{array}{l}3.12 \\
3.22\end{array}$ \\
\hline $\begin{array}{c}\text { FuW mean } \\
\text { sd }\end{array}$ & $\begin{array}{l}5.43 \\
5.27\end{array}$ & $\begin{array}{r}1.96 \\
5.23\end{array}$ & $\begin{array}{l}16.91 \\
15.61\end{array}$ & $\begin{array}{l}2.19 \\
3.02\end{array}$ \\
\hline $\begin{array}{ll}f-t e s t & p= \\
t-t e s t & \text { for }\end{array}$ & 0.75 & $0.00 *$ & 0.01 & 0.16 \\
\hline \multicolumn{5}{|l|}{ contragt } \\
\hline $\mathrm{C}-\mathrm{S} \quad \mathrm{p}^{\mathrm{m}}$ & & 0.88 & 0.05 & \\
\hline$C \rightarrow F$ & & $0.01 *$ & $0.01 *$ & \\
\hline $3-p$ & & $0.00 *$ & 0.28 & \\
\hline
\end{tabular}

Table 7.5 Early functional result per fracture type

Mean and gtandard devation of the functonal result score a week 4 for fracure type 1 and $3(\mathrm{~T} 1 / 3)$, type 2 (T2) and type 4 (T4).

\begin{tabular}{|c|c|c|c|}
\hline & $\pi n$ & $\mathrm{~T} 2$ & T4 \\
\hline $\begin{array}{c}\text { CON mean } \\
\text { sd }\end{array}$ & $\begin{array}{l}33.08 \\
21.24\end{array}$ & $\begin{array}{l}56.72 \\
27.43\end{array}$ & $\begin{array}{l}60.11 \\
24.62\end{array}$ \\
\hline $\begin{array}{l}\text { SAR mean } \\
\text { sdd }\end{array}$ & $\begin{array}{r}23.13 \\
8.86\end{array}$ & $\begin{array}{l}42.52 \\
18.97\end{array}$ & $\begin{array}{l}62.63 \\
24.82\end{array}$ \\
\hline $\begin{array}{c}\text { Fun mean } \\
\text { ad }\end{array}$ & $\begin{array}{l}16.15 \\
14.22\end{array}$ & $\begin{array}{l}43.14 \\
25 \cdot 49\end{array}$ & $\begin{array}{l}47.36 \\
18.20\end{array}$ \\
\hline $\begin{array}{l}\text { b-toge pos } \\
\text { t-tot for } \\
\text { contangto }\end{array}$ & $0.01 *$ & $0.05 *$ & 0.21 \\
\hline $\begin{array}{ll}C-S & p= \\
C-1 & p=r \\
S-F & p=\end{array}$ & $\begin{array}{l}0.08 \\
0.00 k \\
0.06\end{array}$ & $\begin{array}{l}0.03 \\
0.0 / 4 \\
0.80\end{array}$ & \\
\hline
\end{tabular}

Table 7.5 functolonal end result

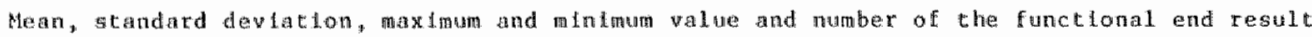
score fot each group.

\begin{tabular}{lcccc}
\hline & CON & SAR & FUN & cota \\
\hline man & 8.56 & 10.00 & 7.21 & 8.71 \\
sd & 8.30 & 10.56 & 6.78 & 8.81 \\
$\max$ & 53 & 49 & 33 & 53 \\
ind & 0 & 0 & 0 & 0 \\
n & 73 & 58 & 43 & 174 \\
\hline
\end{tabular}


Table 7.7 Functional end results for differente fracture cypes

Weat and standard devfation of the functonal end result score for fracture type land 3 (TI/3), type 2 (T2) and type $4(T 4)$.

\begin{tabular}{lllll}
\hline & & $T 13$ & $T 2$ & $T 4$ \\
\hline Con & mean & 4.52 & 9.63 & 12.75 \\
& sd & 3.95 & 7.13 & 12.31 \\
SAR & mean & 3.00 & 9.36 & 1.6 .41 \\
& sd & 2.31 & 8.74 & 13.42 \\
Fur & mean & 4.17 & 6.67 & 12.00 \\
& sd & 4.09 & 5.62 & 9.25 \\
total mean & 4.04 & 8.77 & 1.4 .02 \\
& sd & 3.62 & 7.42 & 12.04 \\
\hline \multirow{2}{*}{ Futest pa } & 0.48 & 0.32 & 0.58
\end{tabular}

Table 7.8 Regression analysis functional end result

Regression analysis with dependent varlable functonal end result score (FR). The represented variables are methods of treatment (SAR, FUN), fracture type (T2, T3, T4), fracture cha-

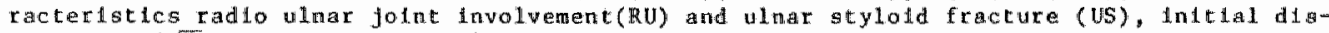
placement $(\sqrt{V 1})$ and comblnatlons of warlables. The vartable $F R$ is transormed to a logarlthm mic scale, the varlable VI is square root trangformed and deducted wh a canstant factor for statistical analytic purposes.

$\log \mathrm{FR}$

\begin{tabular}{|c|c|c|c|c|}
\hline varlable & coete. & st.error & $t-t e s t$ & p-value \\
\hline Intercept & 0.80 & & & \\
\hline $\mathrm{SAR}$ & 0.03 & 0.10 & 0.31 & 0.76 \\
\hline FUN & -0.06 & 0.11 & -0.52 & $0.6 \pi$ \\
\hline $\mathrm{T} 2$ & -0.01 & 0.12 & -0.09 & 0.93 \\
\hline 13 & -0.09 & 0.12 & -0.76 & 0.45 \\
\hline$I_{4}$ & 0.10 & 0.14 & 0.75 & 0.45 \\
\hline$\sqrt{\mathrm{VH}}$ & 0.09 & 0.03 & 3.29 & $0.00 *$ \\
\hline US & 0.17 & 0.09 & 1.89 & 0.06 \\
\hline RU & -0.15 & 0.15 & -1.03 & 0.31 \\
\hline SAR $x$ US & -0.40 & 0.13 & -3.15 & $0.00 *$ \\
\hline FUN $x$ US & -0.07 & 0.14 & -0.50 & 0.62 \\
\hline SAR $\times \mathrm{RU}$ & 0.30 & 0.12 & 2.37 & $0.02 *$ \\
\hline RUN $\times$ RU & -0.01 & 0.14 & -0.07 & 0.95 \\
\hline RU $\times$ T2 & -0.05 & 0.17 & -0.28 & 0.78 \\
\hline $\mathrm{RU} \times \mathrm{T}$ & 0.71 & 0.38 & 1.86 & 0.06 \\
\hline$R U \times 64$ & 0.10 & 0.19 & 0.54 & 0.59 \\
\hline
\end{tabular}


Table 7.9 Coopilication

Munther and pexcentage of complicateris

\begin{tabular}{|c|c|c|c|c|c|c|c|c|}
\hline \multirow[b]{2}{*}{ compl Ications due to cast ox brace } & \multicolumn{2}{|c|}{ cols } & \multicolumn{2}{|c|}{$S A R$} & \multicolumn{2}{|c|}{ FUN } & \multicolumn{2}{|c|}{ cotal } \\
\hline & 5 & $6 \%$ & y & $4 \%$ & 4 & $9 \%$ & 12 & $6 \%$ \\
\hline redialocation medling rerepostlon & 5 & $5 \%$ & 9 & $13 \%$ & 3 & $6 z$ & 17 & 99 \\
\hline Hedlat nerve compression & 8 & $10 \%$ & 5 & $7 \%$ & 3 & 68 & 16 & $8 \%$ \\
\hline Lendon lrijurdes & 6 & $7 \%$ & 0 & $0 \%$ & 1 & $2 x$ & 7 & $4 \%$ \\
\hline Wudech dysutrophy & 7 & $9 \%$ & 5 & $7 \%$ & 2 & $4 \%$ & 14 & $7 \mathrm{r}$ \\
\hline Loss of raido-ulnar thegetity & 13 & $16 \%$ & 8 & $12 \%$ & 4 & $9 \%$ & 25 & $13 \%$ \\
\hline post-raumate arthedte & 13 & $16 \%$ & 12 & $18 \%$ & 6 & 137 & 31 & $16 \%$ \\
\hline las of motion & 6 & $7 \%$ & 11 & $16 \%$ & 4 & $9 \%$ & 21 & $11 \%$ \\
\hline Duptoytren's digabe & 3 & $t_{4} \%$ & 2 & $3 \%$ & 0 & $0 \%$ & 5 & $3: 2$ \\
\hline toted. 1 & 665 & & 55 & & 27 & & 148 & \\
\hline
\end{tabular}

Table 7.10 Distribution of complications

Mumber and percentage of patients wth $0,1,2,3,4$ or 5 complications.

\begin{tabular}{|c|c|c|c|c|c|c|}
\hline number of & compiticatlons & Con & SAR & FuW & tota 1 & $\therefore$ \\
\hline & 0 & $36 \quad 44 \%$ & $3349 \%$ & $2 B \quad 60 \%$ & $9749 \%$ & \\
\hline & 1 & $3239 \%$ & $2030 \%$ & $1430 \%$ & $6634 \%$ & \\
\hline & 2 & $810 \%$ & $1015 \%$ & 24 & $2010 \%$ & \\
\hline & 3 & $67 \%$ & $23 \%$ & $6 \%$ & $116 \%$ & \\
\hline & 4 & $0 \%$ & $1 \%$ & $0 \%$ & $1 \%$ & \\
\hline & 5 & $0 \quad 0 \%$ & $1 \quad 2 \%$ & $0 \quad 0 \%$ & $1 \%$ & \\
\hline total & & 82 & 67 & 47 & 196 & \\
\hline
\end{tabular}

Kruska1-Wallistest $p=0.43$

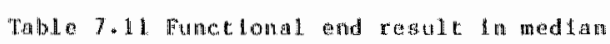
nerve compresstan

Hean, acandard dewation and number of the finct lonal and result scote of three groups of pattents whth median nerve com preasion (MNC), compared to a 1 other Cagest. From 15 aut of the 16 patients, the score could be calleulated.

\begin{tabular}{|c|c|c|c|c|}
\hline & & & & $t-\operatorname{tes} t$ \\
\hline & mean & sid & $\mathrm{n}$ & $p:$ \\
\hline MNC all cases & 10.08 & 8.64 & 15 & \\
\hline Al1 other eases & 8.61 & 8.84 & 159 & 0.58 \\
\hline MNe oferated & 13.67 & 11.18 & 8 & \\
\hline all other caseds & 8.53 & 8.71 & 166 & 0.31 \\
\hline MNC not operated & 6.50 & 2.88 & 7 & \\
\hline all other cases & 8.79 & 8.9 .4 & 167 & 0.13 \\
\hline
\end{tabular}

Table 7.12 Functional and resuld 1 n Sudeck dysteropity

Mean, standatd devlatton and number of the functional end result score of three groups of patients 1 th Sudeck dystrophy (SD), compared to all other cases. From 13 out of the 14 patients, the score could be calculated.

\begin{tabular}{|c|c|c|c|c|}
\hline & mean & sd & $\mathrm{n}$ & $\begin{array}{c}t-\operatorname{tes} t \\
p:\end{array}$ \\
\hline $\begin{array}{l}\text { Si stage } 1+2 \\
\text { al other cases }\end{array}$ & $\begin{array}{r}21.82 \\
7.82\end{array}$ & $\begin{array}{r}16.08 \\
7.38\end{array}$ & $\begin{array}{r}13 \\
161\end{array}$ & $0.02^{*}$ \\
\hline $\begin{array}{l}\text { SD stage } 1 \\
\text { all other cases }\end{array}$ & $\begin{array}{r}17.00 \\
8.41\end{array}$ & $\begin{array}{r}18.01 \\
8.26\end{array}$ & $\begin{array}{r}7 \\
167\end{array}$ & 0.30 \\
\hline $\begin{array}{l}\text { SD stage } 2 \\
\text { all other cases }\end{array}$ & $\begin{array}{r}27.50 \\
8.18\end{array}$ & $\begin{array}{r}12.82 \\
8.07\end{array}$ & $\begin{array}{r}6 \\
168\end{array}$ & $0.03 *$ \\
\hline
\end{tabular}


The 7.13 Functional end resule In loss of radio-ulnar integrity

Hean value, stamerd deviation and nuber of the functional and result score of patlents with loss of radiomlnar integrtty (RLI) compared to all other cases.

\begin{tabular}{|c|c|c|c|c|}
\hline & mean & $5 d$ & n & $\begin{array}{c}t-\operatorname{tas} t \\
p:\end{array}$ \\
\hline $\begin{array}{l}\text { Loss of RUI } \\
\text { all other cases }\end{array}$ & $\begin{array}{r}16.73 \\
7.30\end{array}$ & $\begin{array}{r}13.07 \\
7.00\end{array}$ & $\begin{array}{r}25 \\
149\end{array}$ & $0.00 *$ \\
\hline
\end{tabular}

Table 7.14 punctanal end rabult in posttratuatic arthritis

Hean yalue, standard deviatlon and number of the functional and resulit score of par

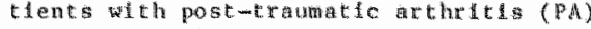
compared to all other cases.

\begin{tabular}{|c|c|c|c|c|}
\hline & mean & $\mathrm{sd}$ & in & $\begin{array}{c}t-\operatorname{tes} t \\
0:\end{array}$ \\
\hline $\begin{array}{l}\text { PA } \\
\text { al ot ther colses }\end{array}$ & $\begin{array}{r}12.79 \\
7.93\end{array}$ & $\begin{array}{r}11.29 \\
8.07\end{array}$ & $\begin{array}{r}31 \\
143\end{array}$ & $0.04 *$ \\
\hline
\end{tabular}

Table 7.15 Anatomical end results for all fracture types

Hean, standard deviation, maximum and mimum value and number of the flnal wollar angle dffterence (V3), radial angle difference (R3), radlal length difference ( 1,3$)$ and radial shift (S3) for all fracture types.

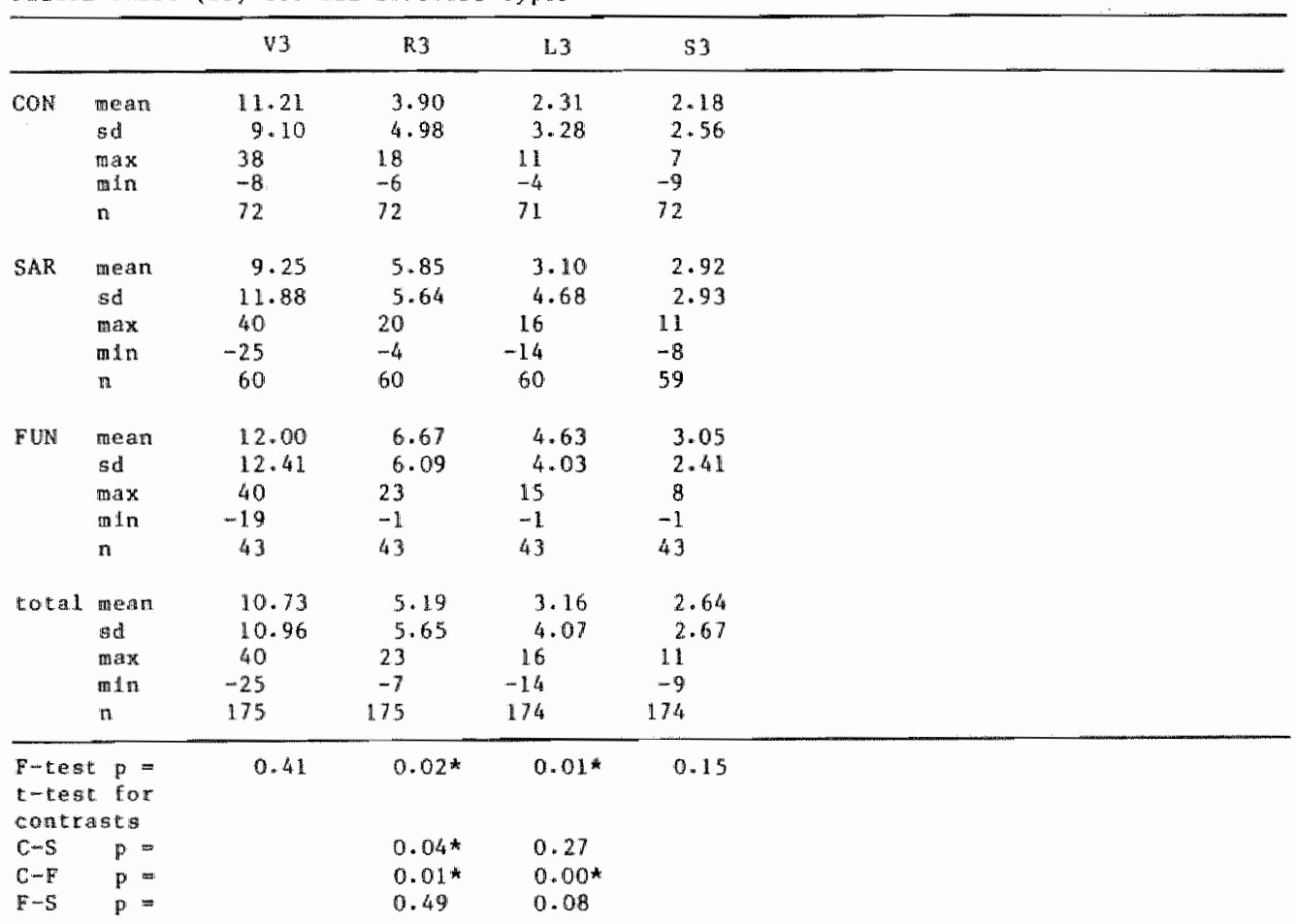




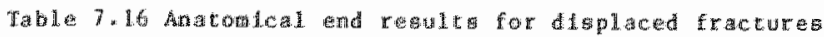

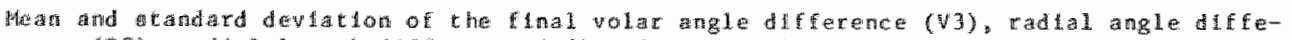
rence (R3), radial Length difference (L3) and radlal shite (S3) for displaced fractures $(12 / 4)$

\begin{tabular}{|c|c|c|c|c|c|}
\hline & & $\sqrt{3}$ & $\mathrm{R}_{3}$ & 43 & 53 \\
\hline Con: & $\begin{array}{l}\text { mesin } \\
\text { gd }\end{array}$ & $\begin{array}{l}13.65 \\
9.64\end{array}$ & $\begin{array}{l}5.02 \\
4.97\end{array}$ & $\begin{array}{l}3.22 \\
2.94\end{array}$ & $\begin{array}{l}2.67 \\
2.41\end{array}$ \\
\hline $\mathrm{SAR}$ & $\begin{array}{l}\text { nat } \\
\text { sd }\end{array}$ & $\begin{array}{l}10.52 \\
12.97\end{array}$ & $\begin{array}{l}7.04 \\
5.57\end{array}$ & $\begin{array}{l}4.00 \\
4.84\end{array}$ & $\begin{array}{l}3.31 \\
3.15\end{array}$ \\
\hline F bly & $\begin{array}{l}\text { mean } \\
\text { ad }\end{array}$ & $\begin{array}{l}13.59 \\
13.29\end{array}$ & $\begin{array}{l}8.09 \\
6.12\end{array}$ & $\begin{array}{l}5.56 \\
4.15\end{array}$ & $\begin{array}{l}3.56 \\
2.54\end{array}$ \\
\hline total & $\begin{array}{l}\text { mean } \\
\text { ad }\end{array}$ & $\begin{array}{l}12.48 \\
11.93\end{array}$ & $\begin{array}{l}6.57 \\
5.61\end{array}$ & $\begin{array}{l}4.12 \\
4.12\end{array}$ & $\begin{array}{l}3.14 \\
2.74\end{array}$ \\
\hline $\begin{array}{l}\mathrm{E}-\mathrm{te} t \\
\mathrm{c}-\mathrm{tes} \\
\text { contra }\end{array}$ & $\begin{array}{l}\text { p } \\
\text { for } \\
\text { a to to }\end{array}$ & 0.38 & $0.04 k$ & $0.05 *$ & 0.32 \\
\hline$C-5$ & $p=$ & & 0.07 & 0.35 & \\
\hline $\begin{array}{l}C-F \\
F-5\end{array}$ & $\begin{array}{l}p= \\
p=4\end{array}$ & & $\begin{array}{l}0.02^{\text {th }} \\
0.44^{4}\end{array}$ & $\begin{array}{l}0.01 * \\
0.13\end{array}$ & \\
\hline
\end{tabular}

Tabe1 7.17 Anatomlcal end results for minimally displaced fracturesi

Mean and atandard dewlation of the tinal vollar angle difference (V3), radtal angle diffetence (R3), radial length difference (L3) and radtal shift (53) for intinally displaced fractures (T1/3).

\begin{tabular}{|c|c|c|c|c|c|}
\hline & & v3 & $\mathrm{R} 3$ & 13 & 53 \\
\hline CON & $\begin{array}{l}\text { me a n } \\
\text { sid }\end{array}$ & $\begin{array}{l}6.89 \\
6.11\end{array}$ & $\begin{array}{l}1.50 \\
4.61\end{array}$ & $\begin{array}{l}0.73 \\
3.29\end{array}$ & $\begin{array}{l}1.31 \\
2.62\end{array}$ \\
\hline SAR & $\begin{array}{l}\text { me al th } \\
3 . d\end{array}$ & $\begin{array}{l}5.07 \\
5.79\end{array}$ & $\begin{array}{l}1.93 \\
3.93\end{array}$ & $\begin{array}{l}0.14 \\
2.38\end{array}$ & $\begin{array}{l}1.64 \\
1.50\end{array}$ \\
\hline FUN & $\begin{array}{l}\text { mean } \\
\text { dd. }\end{array}$ & $\begin{array}{l}7.36 \\
8.21\end{array}$ & $\begin{array}{l}2.55 \\
3.75\end{array}$ & $\begin{array}{l}1.91 \\
1.97\end{array}$ & $\begin{array}{l}1.55 \\
1.04\end{array}$ \\
\hline totial & $\begin{array}{l}\text { mean } \\
\text { gdil }\end{array}$ & $\begin{array}{l}6.49 \\
6.46\end{array}$ & $\begin{array}{l}1 \cdot 84 \\
4 \cdot 20\end{array}$ & $\begin{array}{l}0.82 \\
2.84\end{array}$ & $\begin{array}{l}1.45 \\
2.06\end{array}$ \\
\hline$f^{2}-t e d t$ & $p$ & 0.62 & 0.79 & 0.30 & 0.88 \\
\hline
\end{tabular}




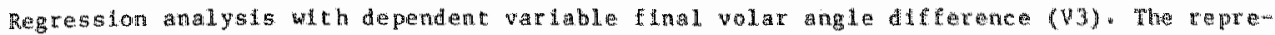

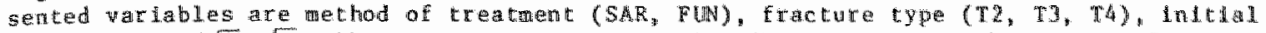

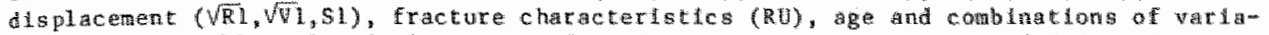
bles. The variables Rl and Vl are transformed to square root scale and deducted with

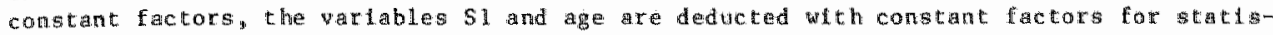
tical analytic purposes.

V3.

\begin{tabular}{|c|c|c|c|c|}
\hline vartable & coeff. & st.error & $t-t e s t$ & $p$-value \\
\hline Intercept & 21.64 & & & \\
\hline$S A R$ & -1.85 & 1.77 & -1.05 & 0.30 \\
\hline FUN & 0.37 & 1.97 & 0.19 & 0.85 \\
\hline 12 & $-1 \cdot 34$ & 3.26 & -0.41 & 0.68 \\
\hline$\pi$ & -0.63 & 3.18 & -0.20 & 0.8 .4 \\
\hline$T 4$ & $-1 \cdot 24$ & 3.39 & -0.37 & 0.72 \\
\hline$\sqrt{81}$ & 5.80 & 1.66 & 3.50 & 0.00 \\
\hline$\sqrt{ } 1$ & 0.76 & 1.00 & 0.76 & 0.45 \\
\hline S1 & -1.97 & 0.56 & -3.51 & 0.00 \\
\hline RU & 0.9 .4 & 1.73 & 0.54 & 0.59 \\
\hline $\operatorname{age}$ & 0.01 & 0.05 & 0.32 & 0.75 \\
\hline $\operatorname{age} \times 51$ & -0.06 & 0.02 & -3.18 & 0.00 \\
\hline $\mathrm{RU} \times \sqrt{\mathrm{RL}}$ & -6.97 & 2.30 & -3.03 & $0.00 *$ \\
\hline RU $x \sqrt{\mathrm{v}}$ & 2.41 & 1.19 & 2.02 & $0.05 *$ \\
\hline $\mathbb{R} U \times \mathbb{~} \mathbb{1}$ & 2.10 & 0.78 & 2.68 & 0.01 * \\
\hline
\end{tabular}

Table 7.19 Regression anallysts finall radial angle difference

Regression andysis with dependent varlable flnal radlal angle dfference (R3). The represented variables are methods of treatment (SAR, FUN), fracture type (T2, T3, T4), Int t al d 1 splacement $(\sqrt{R} 1)$ and age. The vartable R3 is transformed to a square roots sicale, the wit rlable R. is transformed to a square root scale and deducted with a constant factar, the vartable age is deducted with a constant factor for statistical analyte purposes. $\sqrt[4]{8} 3$

\begin{tabular}{|c|c|c|c|c|}
\hline vartable & $\cos E l$ & st.urror & $t-t$ est & p-value \\
\hline Intercept & 2.92 & & & \\
\hline$S M$ & 0.20 & 0.13 & 1.59 & 0.11 \\
\hline Ellow & 0.44 & 0.14 & $3 \cdot 1.4$ & $0.00 *$ \\
\hline $\mathrm{T} 2$ & 0.21 & 0.16 & 1.29 & 0.20 \\
\hline$T^{3}$ & 0.11 & 0.23 & 0.49 & 0.63 \\
\hline$T 4$ & 0.10 & 0.18 & 0.56 & 0.157 \\
\hline$\sqrt{\mathbb{R I}}$ & 0.47 & 0.07 & 6.91 & $0.00 *$ \\
\hline age & 0.01 & 0.00 & 3.26 & $0.00 *$ \\
\hline
\end{tabular}




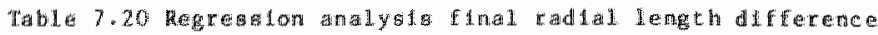

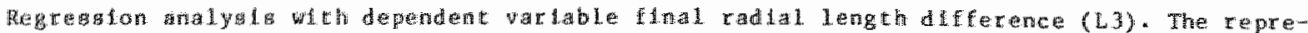

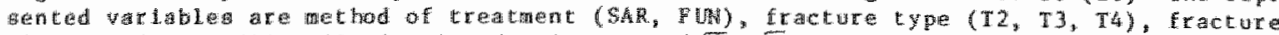

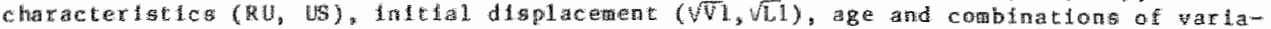

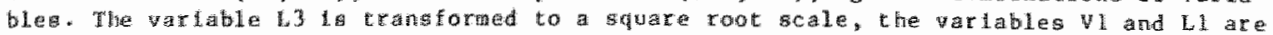
trangforted to aquare root scale and deducted with contant factors, the vartable age is deducted wh a constant factor for statiolcal analytic purposes.

$\sqrt{L^{3}}$

\begin{tabular}{|c|c|c|c|c|}
\hline Wartable & coet. & gtertor & $t-t e s t$ & $p-v a l$ ue \\
\hline Interetept & $4 \cdot 26$ & & & \\
\hline $\mathrm{SAR}$ & -0.00 & 0.06 & -0.03 & 0.98 \\
\hline FUN & 0.19 & 0.07 & 2.93 & 0.00 \\
\hline 72 & 0.12 & 0.12 & 0.16 & 0.87 \\
\hline 73 & 0.01 & 0.11 & 0.08 & 0.94 \\
\hline $\mathrm{T} / \mathrm{s}$ & 0.01 & 0.12 & 0.09 & 0.93 \\
\hline $\mathrm{RU}$ & -0.02 & 0.06 & -0.41 & 0,68 \\
\hline U:S & -0.04 & 0.06 & -0.63 & $0.5 y$ \\
\hline$\sqrt{\mathrm{VL}}$ & 0.03 & 0.03 & 0.76 & 0.45 \\
\hline$\sqrt{L} 1$ & 0.47 & 0.07 & 6.64 & $0.00 *$ \\
\hline age & 0.01 & 0.00 & 3.06 & $0.00 *$ \\
\hline $\mathrm{RU} \times \sqrt{\mathrm{N}}$ & -0.07 & 0.03 & -2.07 & $0.04 \%$ \\
\hline $15 \times \sqrt{\mathrm{Cl}}$ & -0.16 & 0.08 & 1.92 & 0.05 \\
\hline
\end{tabular}

mult tple R-square: $0.49 \%$

Table 7.21 Regression analysta final radlal shift

Regression analyols with dependent varlable flnal radial shift (S3). The represented varlables are methods of treatment (SAR, FUN), fracture type (T2, T3, T4), inltial displacement ( $\sqrt{2}, \sqrt{L}, S 1)$, age and comblnations of varlables. The varlables Rl and Ll are tranformed to a Logaritimic scale and deducted with constant factors, the warlables $5 t$ and age are dedncted with constant factors for statistical analytic purposes.

s3

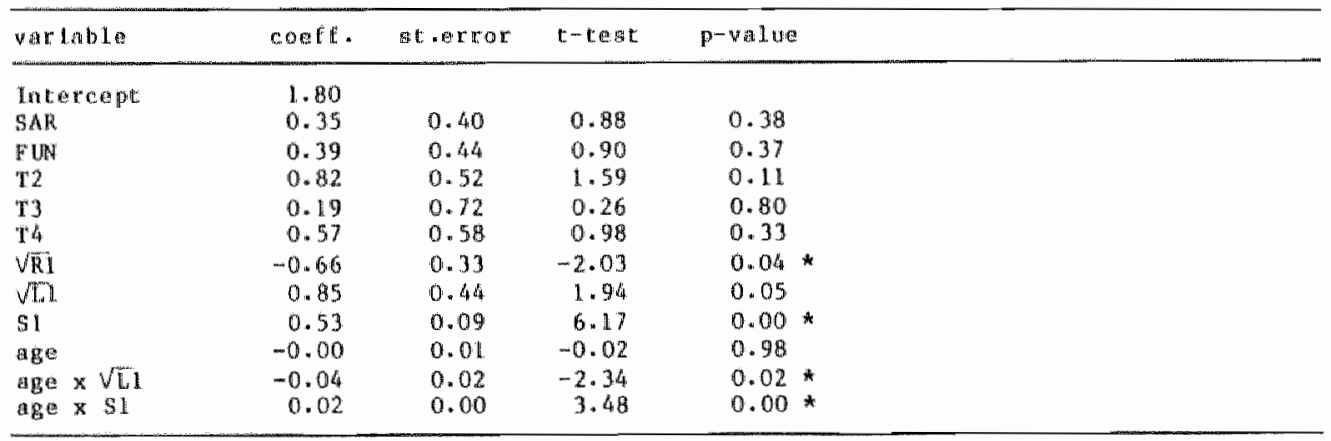

multiple R-square: $0.39 \%$ 
Figure 7.22 Correlation anatonat-functonal end result

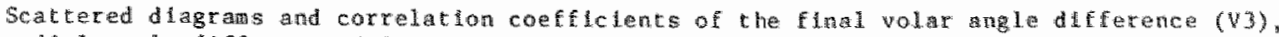

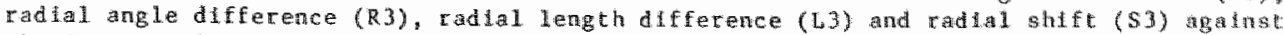
the functonal end result score (F) for all cases.
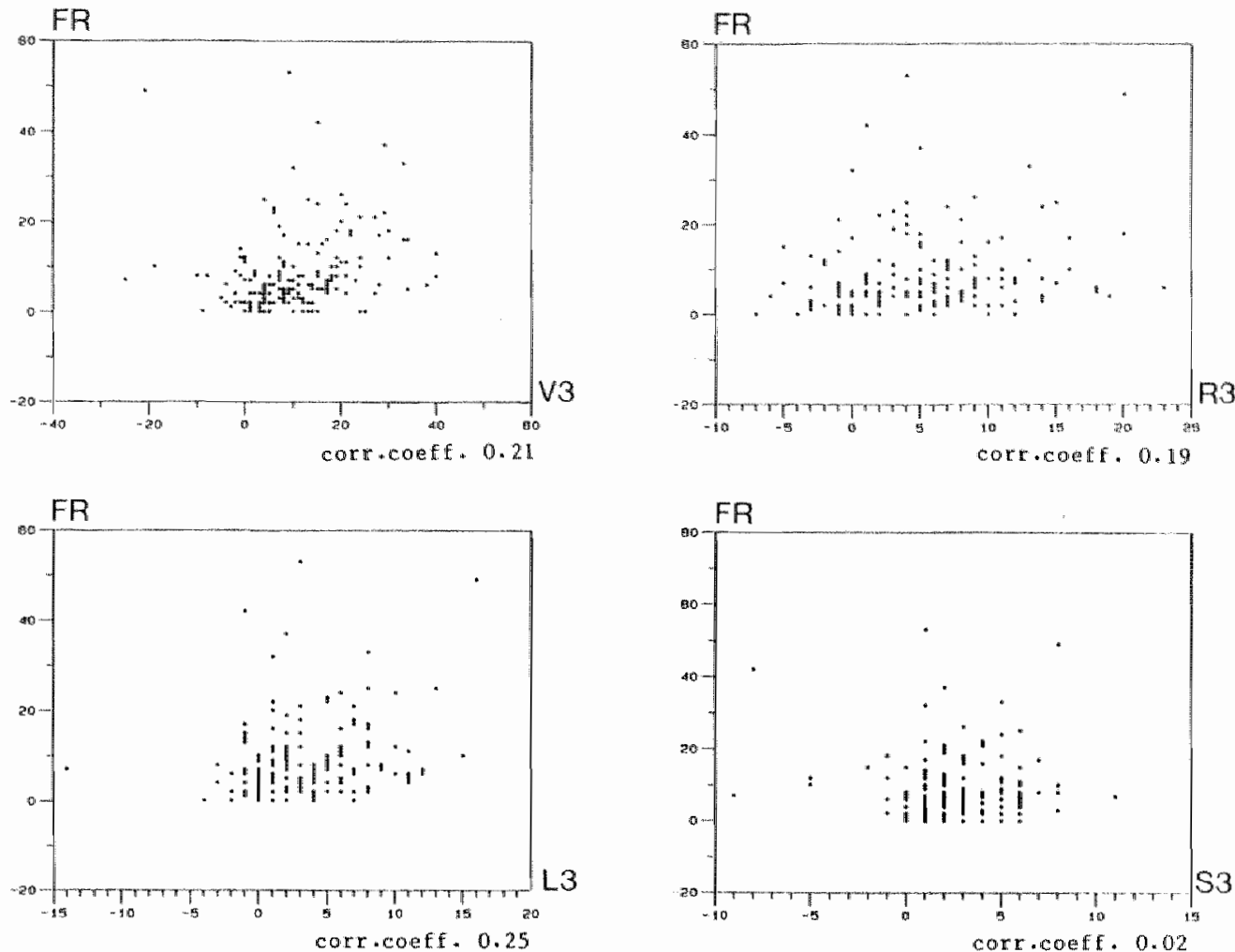

Table 7.23 Correlation coeffelent

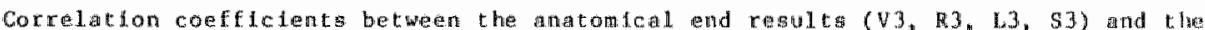
functional end result scores for different gromp of age or fracture type.

\begin{tabular}{|c|c|c|c|c|c|}
\hline & $\mathrm{n}$ & $\sqrt{3}$ & R3 & L3 & $\$ 3$ \\
\hline all cases & 166 & 0.21 & 0.19 & 0.25 & 0.02 \\
\hline $\mathrm{T} 2 / 4$ & 117 & 0.31 & 0.04 & 0.15 & -0.10 \\
\hline T1/3 3 & 49 & 0.26 & 0.27 & 0.14 & -0.01 \\
\hline age $>50$ & 120 & 0.31 & 0.09 & 0.13 & -0.10 \\
\hline age $\leqslant 50$ & 46 & 0.07 & 0.40 & 0.54 & 0.22 \\
\hline age $\leqslant 50, \mathrm{~T} 2 / 4$ & 29 & -0.16 & 0.29 & 0.51 & 0.19 \\
\hline age $\leqslant 50$, Ti/3 & 17 & 0.27 & 0.15 & -0.11 & -0.20 \\
\hline age $\leqslant 50$, T2 & 19 & 0.26 & 0.06 & 0.29 & 0.06 \\
\hline $\mathrm{age} \leqslant 50, \mathrm{~T} 4$ & 10 & -0.26 & $0.4,5$ & 0.60 & 0.25 \\
\hline
\end{tabular}




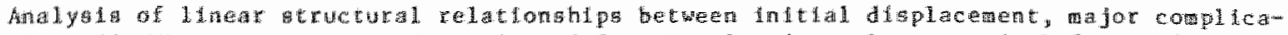
thone (Cotpl), anatomleal end result and functonal end resulc score (FR) for patents of

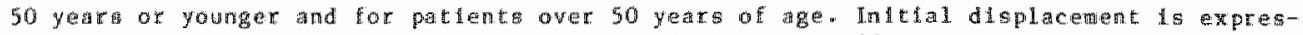

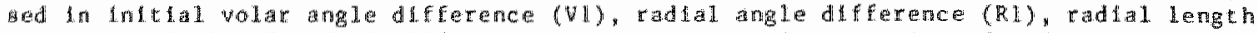
difference (L) and radial ghlet (51). Whar complications conslst of Sudeck dystrophy me-

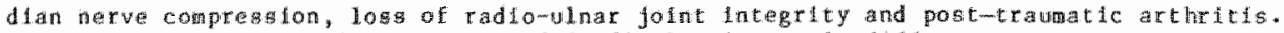

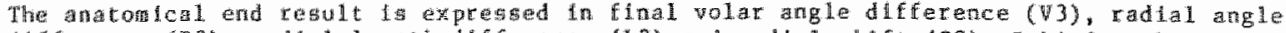

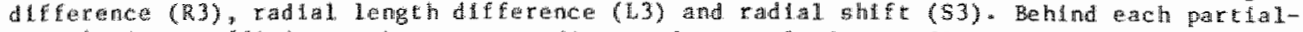
correlation coeffletent, the cortegonding ctude-correlation coef letant ls indicated in parenthests. The percentage of unewplathed vartance of the vartows parameters is indicated

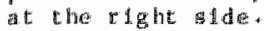

age $<50$ MNITHAL

$n=38$ DISPLACEMENT

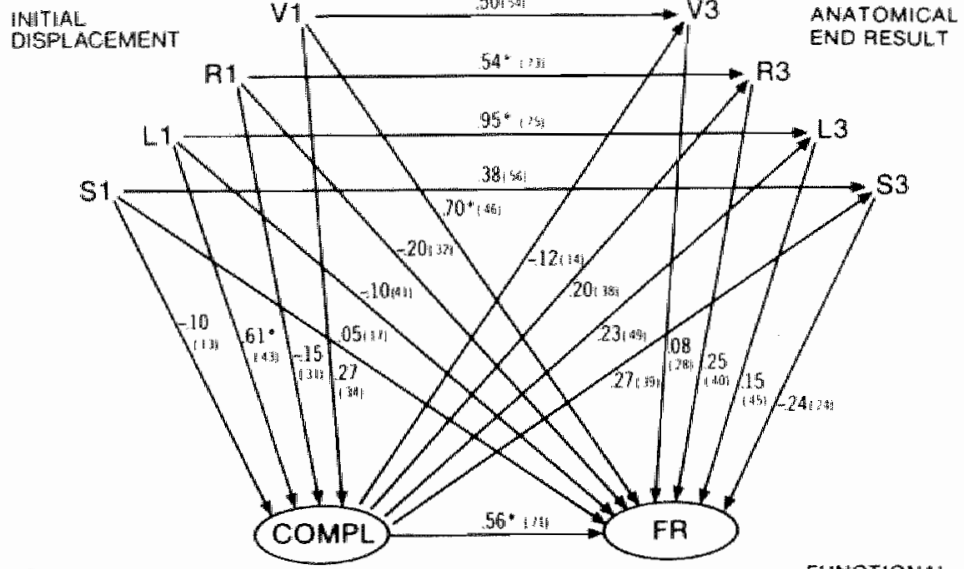

COMPLICATIONS

FUNCTIONAL

ENID RESULT percentage of unexpl alined varlance

FR: $\quad 36 \%$

COMPL: $73 \%$

प3: $57 \%$

R.3: $\quad 33 \%$

1.3: $\quad 34 \%$

S3: $\quad 48 \%$ age $>50$ NIIIUALL

$n$ DISPLACEMENT
$\mathrm{AJ}^{\circ} \mathrm{Pin}$

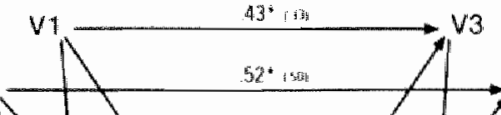

ANATOMICAL FR: $64 \%$ END AESULT COMPL: $86 \%$

Vi: $72 \%$

स 3: $65 \%$

1. 3: $\quad 70 \%$

S3: $\quad 62 \%$

GOMPLICATIONS 


\section{DISCUSSION AND CONCLUSIONS}

\subsection{Discussion}

In the evaluation of treatment outcome, the wrist was considered as a "black box". This approach was based on the assumption that the patient will not complain of structural damage inside the wist, but that the patient wight be disabled by the results and consequences. Therefore no efforts were made to analyse structional damage inside the wrist. (except for radiographic examinations, necessary for analysis of relationships). The criteria for treatment outcome comparison used in this study were the speed of functional recovery, the functional end result and the incidence of complications. The anatomical end result was not used as a criterium.

The speed of functional recovery and functional end result were scored by a newly developed score system that considered the disability caused by the injury. Contrary to common score systems the functional recovery was assessed for the first time, all parameters were precisely defined, and the degree of disability resulting from loss of motion was rated according to generally accepted criteria. The uninjured wrist served as the individual standard, which prowed to be inportant as a wide range of normal values was found in uninjured wrists. The results were not classified into groups with an excellent, good, falr or poor outcome as conmonly encoutered in literature, as this would be arbitrarily, unnecessary and would result in for this study unwanted simplifications.

The new score system was designed to evaluate all possible important aspects of the functional result. This resulted in a wide score range. Because of large interpatient variability (especially in the beginning of the rehabilitation period) this wide range proved to be of value. The score system, however, is complicated and needs computer assistance. For that reason it seems unpractical and unsuitable for common use.

All complications during one year were considered to be related to the colles fracture injury. The occurrence of median nerve compression or Dupuytren's disease in some cases might have been coincidental. "Mhis is however, hard to estimate as no exact flgures exist about the incidence of these complications in the normal population $(64,99)$.

The outcome of the study indicates that:

1. In displaced fractures functional treatment with a below-the-elbow functional brace and with samiento"s functional brace in supination are only superior to conventional plaster treatment in cases of extra-articular fractures by providing a faster functional recovery early in the rehabilitation phase (Hypotheses 1 and 2).

2. In minimally displaced fractures, functional treatment with a bandage is only superior to conventional plaster treatment giving a faster functional recovery early in the rebabilitation phase (Hypothes is 3 ). 
3. The causal relationship between the anatonical end result and the functonal end result in this study is very weak (Hypothesis 4 ).

These conclusions lead to some practical consequences for the treatment of Golles fractures:

- For displaced extra-articular fractures (Samiento Type 2) the limited gain obtalned in speed of functional recovery with a below-the-elbow Eunctional brace when compared to a conventional plaster has to be weighed in individual cases against the increased costs, necessary to apply the device.

- Sarmiento's functional brace in suplnation should not be used as it has no advantages when compared with a below-the-elbow functional brace but only disadvantages (more difficult to apply and less convenient for the patient).

- For displaced intra-articular fractures (Samiento Type 4) functional treatment should not be used.

- For mintily displaced fractures (Sarmiento Type 1 and 3) functional treatment with a bandage after one week immobilisation is the method of cholce. Four weeks of fmmoblisition should be regarded as overtreatment for this fracture type.

- The inferior anatomical results obtained by the different types of functional treatment in this study are not shown to be detrimental to the functional results obtained with these methods of treatment.

Sumarising the conclusions it appears that the benefits of functional treatmert of colles fractures are rather limited compared to four weeks of plaster treatment. However, treatment with a below-the-elbow plaster during only four weeks is also a rather functional approach because pronation and supination in the forearm are not fully restricted. If the functional treatment as applied in this study had been compared with a longer and more rigid immobilisation method of treatment the differences might have been greater.

The study extended over a follow up period of one year. Results at one year were regarded as representing the end results. With respect to the functional end result, this assumption seems acceptable as the functtonal score tended to stabilise during the second half of the year. The anatomical result is very unlikely to change after the follow up period. The fncidence of the complications will not change after one year with the possible exception of post-traumatic arthritis which might influence the end results over a longer perlod. After one year this complication seemed unrelated to a poor anatomical end result. Future investigations however, are necessary to evaluate whether this finding remains the same in the long run.

Some remarks can be made when contrasting this study to the literature: Contrary to the majority of investigations this study is prospective and comparative with a standardised management of the injury and with precise defintions.

For the first time the speed of functional recovery, and the causal relationshlp between anatonical and functional end result are evaluated. The superior functional and anatomical end results of functional bracing In supination over plaster cast treatment as claimed by Sarmiento et al $(159,162)$ and Bunger et al (26) could not be confirmed. 
This study supports the conclusion of Stewart et al (178) that no sign ificant difference exists in the functional end result and the incidence of complications between plaster treatment and functional treatment.

The faster functional recovery, as claimed by samiento, appeared only short lived and was restricted to some fracture types.

The impression that complications after colles fractures are relatively comon and a reason for unsatisfactory end results could be confluted. Contrary to the opinion of the majority of the authors no mportant causal relationship between the anatomical and functional end result was found. This discrepancy might be due to the mixing up af correlation and causal relationship. The positive correlation between anatonlcal and functional result reported by some authors can be explained by the fact that both factors are causally related to a mutual factor: the initial displacement, possibly reflecting the severity of the injury * Howewer, from such a possitive correlation a causal relationship cannot be concluded beforehand.

In search of the most beneficial type of functional treatment, different types were evaluated. The hardly existing causal relationship between the anatomical and functional end result means no contra-indication for further investigation on other types of functional treatment, restricting even less motion, with consequently higher chances of infertor anatomical results. However, the outcome of this study does not urge such further investigation as the benefit of functional treatment over conventional plaster treatment is rather 1 imited.

The functional end result depends more on the initial displacenent and on the occurrence of complications than on the method of treatment. The initial displacement cannot be influenced. Investigations on prevention and better treatment of major complications might therefore be the new frontier in the search for better functional end results after colles fractures.

\subsection{Conclusions}

The application field of functional treatment in the management of colles fractures is rather 1 inted, when compared to conventional plaster treatment.

Sarmiento's functional bracing in suplnation has no place in the management of Colles fractures.

Functional bracing with a below-the-elbow brace has some slight advantage over conventional plaster treatment in displaced extra-articular Col les fractures.

Functional treatment with a bandage for three weeks after one week immobilisation is the method of choice in Colles fractures without in itial dorsal angulation. 
The calusal relationship between the anatomical end result and the functlonal end result is weak in Colles fractures that are managed as described in thls study.

The rost inportant causal factors influenctig the functional end result are not the method of fracture treatment, nor the anatomical end result, but the inftial displacement of fracture fragments and the occurrence of complications.

For evaluation of functional and anatomical end results in colles fractures, the non-injured wrist should serve as the individual standard because of large interpatient variability of nomal values.

In Sarafiento"s fracture classification, Type 1 and 3 should be changed to form one type of mininally displaced fractures (i.e. fractures without dorsal angulation).

Investigations on complications after colles fractures might result in a betcer treatment outcome for this injury. 


\section{CHAPTER 9}

\section{SUMMARY}

\section{Chapter 1 Introduction}

Functional treatment is a recently developed approach to a fracture injury with emphasis on early motion and function whereby fracture fragments are not inmobilised but only stabilised. It is based on the assumption that especially soft tissue healing is important for proper rehabilitation. This aspect is given priority over bone consolidation in anatomical position. Retrospective studies indicate rewarding results of functional treatment in the management of colles fractures. The aim of this thesis is to establish the application field of functional treatment of colles fractures by comparing results from functional treatment with conventional plaster treatment in a prospective clinical study.

Chapter 2 The normal wrist and hand, review of litterature

The motion in the wrist region, the function of the hand and the radiological anatomy are described as far as these appear relevant to this study.

Chapter 3 The colles fracture, review of literature Many aspects of the Colles fracture injury and its management are subject to controversial opinions. The results of various studies reporting different methods of treatment are hardly comparable. Very few prospect1ve studies have been performed. The relation between the anatomical and functional result is crucial in the indication for most methods of treatment. This relationship however, remains unrevealed as the existence of a correlation is disputed and because the existence of a causal relationship between the anatomical and functional end result has never been investigated. The only reported type of functional treatment of colles fractures is Sarmiento's functional bracing in supination, which is advocated regardless of the stability of the fracture. It appears that the current methods of treatment outcome evaluation show major drawbacks.

Chapter 4 Design of the study

Fracture stability and the kind of relationship between the anatomical and functional result seem important factors to determine the most beneficial type of functional treatment. Both factors are constdered in the formulation of hypotheses that were tested in the cilnical study. The criteria used for treatment outcome comparison are speed of functional recovery, functional end result and incidence of complications.

Chapter 5 Methods.

The study was perfomed from 1981 till 1984. The patients were selected according to fixed criterla. Three treatment groups were formed. One group was treated with a conventional below-the-elbow plaster. The second group was treated with Sarmiento's above-the-elbow functional brace in supination that permited early volar flexion and ulnar deviation but restricted pronation of the forearm. In the third group displaced fract- 
ures were treated with a below-the-elbow functional brace that permited early volar flexton, ulnar deviation and pronation and supination in the forearm; minimally-dlsplaced fractures (volar angle $>0$ ) were trated wth a bandage that allowed motion 1 all directions. All fractures in the second and third group were intially immoblised with a plaster splint for one week to reduce pain and swelling. The total period of immobilisation or stabiligation in all groups was four weeks. All other aspects of the management of the injury were standardised.

A new score gystem for the functional recovery and functional end result 18 presented which reflects the patient's disability. The criteria for the diagnosis of complications are described. The anatomical result is based on four radlographic parameters. The fracture type is classifled according to sarmiento. The statistican methodology is outlined.

\section{Chapter 6 patient population}

The total number of patients that participated in the study is 196; predominantly elderly women. Characteristics of the patient population like right-left distribution, fracture type distribution, initial displacerent and quality of reduction are presented.

\section{Chapter 7 Results}

In the third, most functional treatment group, the speed of functional recovery is linitilly faster than in the other two groups for displaced extra-articular fractures treated with a below-the-elbow functional brace and for mininally-dlsplaced fractures treated with a bandage. Also in the second group, treated with Sarmiento's brace in supination, an initially faster functional recovery is found compared to the conventional treated group, but only for displaced extra-articular fractures. In displaced intra-articular fractures, no difference in speed of functional recovery between the three treatment groups is found. The functional end result and the incidence of complications is not different in the three treatment groups. The anatomical end result of initially displaced fractures is in the third, most functional group, inferior to the first group treated with a plaster.

The causal relationship between the anatomical and functional end result is very weak. The initial displacement is a relatively important factor influencing both the Eunctional and anatomical end result. Major complicationg appear another relatively important factor influencing the functional end result.

Chapter 8 Discussion and conclusions

The rather complicated newly developed score system is a keystone for the results and conclusions of this study. Functional treataent with a below-the-elbow functional brace appears beneficial in some selected cases of displaced extra-articular fractures. For minimally displaced fractures, a bandage for three weeks after one week immobilisation is the treatment of choice. Functional treatment should not be used for displaced intra-articular fractures. There is no place for functional treatment with Samiento's above-the-elbow functional brace. The overall importance of functional treatinent of colles fractures is rather limited when compared to conventional plaster treatment. This conclusion is in contrast to most reports in literature concerning this subject. 
The positive correlation between the anatonical and functional end result, as reported by some authors, can be explained from the fact that both results depend on the same causal factor; the indtal displacement. From this correlation a causal relationship between the anatonical and functional end result should not be concluded beforehand.

The hardly existing causal relationship between the anacomical and functional end result does not restrict further investigations of functional treatment types with more early motion and function and therefore with a higher chance on inferior anatonical results. The conclusions from this study however, do not indicate a need for further investigations in this direction.

Not the method of treatment, nor the anatomical end results, but the initial displacement, and complications are the most important factors in determining the functional end result, of the latter two, the initial displacement cannot be influenced. Therefore, research on the complications after colles fractures might be the new frontier in improving the treatment outcome of a colles fracture injury. 



\section{SAMENVATTING}

Hoofdstuk 1 , Inleiding

Funktionele behandeling is een recent ontwikkelde vorm van frakturbehandeling waarbij de nadruk wordt gelegd op vroegtijdige beweging en funktie. De fraktuur wordt hiertoe niet gelmobiliseerd doch alleen gestabiliseerd. Deze benadering berust op de veronderstelling dat de weke delen genezing van groter belang is voor een gunstig herstel dan strikte anatomische consolidatie. In retrospectieve studies worden veelbelovende resultaten vermeld van funktionele behandeling van colles frakturen. Het doel van deze studie is om door middel van een prospectief klinisch onderzoek het toepassingsgebied van deze behandelingsvorm voor colles frakturen te evalueren, door resultaten van functionele behandeling te vergelijken met die van conventionele fraktuurbehandeling met behulp van een gipsspalk.

Hoofdstuk 2, Literatuuroverzicht van de normale pols en hand Van functionele en röntgenologische aspekten van de normale hand en pols wordt een overzicht gegeven, voor zover dit relevant is voor de opzet van de studie.

Hoofdstuk 3, Literatuuroverzicht van de colles fraktuur Over de meeste aspekten van het colles fraktuurletsel blijken controversiële meningen te bestaan. De uitkomsten van velerlei studies over verschillende behandelingsmethoden zijn nawwelijks onderling te vergelijken. Het aantal gepubliceerde prospectieve studies is gering. Het veronderstelde verband tussen het anatomische en functionele eindresultaat is de basis voor de indicatiestelling van de meeste behandelingsvormen. Dit verband blijft echter onopgehelderd aangezien de meningen over een correlatie tussen beide verdeeld zijn en angezien een oorzakelijke verband tussen beide noolt onderzocht blijkt te zijn. De funktlonele behandeling volgens Sarmiento is de enige tot nu toe beschreven vorm van funktonele behandeling van colles frakturen. Deze wordt ongeacht de stabiliteit bij ledere Colles fraktuur aangeraden.

Tenslotte bijiken de gangbare evaluatiemethoden van behandelingsresultaten belangrijke tekortkomingen te vertonen.

Hoofdstuk 4 , Onderzoeksopzet

De fraktuurstabiliteit en het verband tussen het anatomische en functionele eindresultaat lijken belangrijke factoren te zijn voor het bepalen van de meest optimale vorm van functionele behandeling . Deze belde factoren zijn betrokiken bij het formuleren van de hypothesen die $\mathrm{ln}_{\mathrm{n}} \mathrm{de}$ kilnische studie getoetst zijn. Als criteria voor de vergelijking van resultaten dienen de snelheid van het funktionele herstel, het funktionele eindresultaat en de incldentle van complicaties. 
Hoofdstuk 5, Hethoden

De wudle werd verricht van 1981 tot 1984 . De patientenpopulatie kwam tot stand volgens vooropgestelde criteria. Er werden drie behandelingsgroepen sanengesteld. Groep 1 werd gexmoblilseerd met een conventionele onderarmsgipsspalk. Groep 2 werd behandeld met een tot boven de elleboog relkend funktonele koker volgens Sarmiento, warbij volaire flexie en ulnaire deviatle toegestaan werden doch warbij rotatie van de onderarm beperkt werd. In groep 3 werden verplaatste frakturen behandeld met een. funtonele onderaris koker warbij volalxe flexie, ulnaire deviatie en onderarasrotatie mogelijk waren. Minimal verplaatste frakturen (volaire hoek groter dan $0^{\circ}$ ) werden in deze groep behandeld met een zwachtel wardoor alle bewegingen mogelijk waren. Alle frakturen in de $2 e$ en $3 e$ groep werden in het begin gedurende Ến week met een gipsspalk gelmobi14serd. De totale immobilisatie of stabilisatie tijd in alle drie de behandelingsgroepen was vier weken. De overige onderdelen van de behandeling van het trauma werden gestandariseerd. Een nieuw score systeem voor het funtlonele herstel en het funtionele eindresultaat werd ontwikke1d.

De criterla voor de diagnostiek van complicaties worden beschreven. De beoordeling van het anatomische resultaat geschiedt op grond van vier radiologische parameters. Voor de fraktur klassificate wordt Sarmiento"s indeling gebrulkt. Er wordt een beschrijving gegeven van de gebruike statistische methodieken.

Hoofdstuk 6, De patiènten populatie

In total zijn 196 patienten in het onderzoek betrokken. Het merendee 1 hiervan betreft vrouwen van middelbare en hogere leeftijd. Gegevens over de 1 inks-rechts verdeling, de frequentie der fraktuur typen, de oorspronkelifke frakturverplaatsing en de mate van succes van de fraktuur repositie worden vermeld.

Hoofdstuk 7, Resultaten

In groep 3 , de meest funtionele behandelingsgroep, wordt in het begin een sneller funktioneel herstel gevonden dan in de andere twee groepen. Dit blijkt te berusten op een significant sneller funkioneel herstel bij verplatste extra-articulaire frakturen en bij minimal verplateste frakturen. In groep 2, behandeld met de functionele bovenarmskoker in supinatie volgens Sarulento, wordt bif verplatste extra-articulaire frakturen in het begin een sneller functioneel herstel gevonden ten opzichte van de conventioneel behandelde groep. Bij verplatste intra-articulatre frakturen wordt geen verschil in funktioneel herstel tussen de drie behandelingsgroepen gevonden. Zowel het funktonele eindresultaat als de incldentie van complicaties verschillen in de drie behandelingsgroepen niet signiflcant. Het anatomische elndresultat van oorspronke1ijk verplatste frakturen blifkt in de meest funtionele behandelingsgroep (groep 3 ) inferieur te zijn in vergelijking tot de conventioneel behandelde groep.

Er blijkt nauwelijks een oorzakelijk verband tussen het anatonische en funktionele eindresultat te bestaan. (Bij frakturen die behandeld zijn zoals in deze studle, warbij repositie en handhaven van een redelijke anatomische stand aandacht krijgen). De oorspronkelijke fraktuurverplatsing en het optreden van complicaties blijken de belangrijkste bepalende faktoren van het funtionele eindresultat te zijn. Dok blijkt de oorspronkelijke fraktururverplaatsing de belangrijkste bepalende factor voor het anatomische eindresultaat te zijn. 
Hoofdstuk 8 , Discussle en conclusies

De resultaten en conclusies zijn voor een belangrijk deel gebenseerd op uitkomsten van het niew ontwikkelde vrij gecompliceerde evaluatiesysteem woor het funktionele herstel en het funktionele eindresultad. Uit de uitkomsten van deze studie wordt geconcludeerd dat funktomele behandeling met een funktionele onderamskoker in sommige gevallen wan extraarticulaire colles frakturen van nut kan zijn. Voor frakturen zonder oorspronkelijke dorsale angulatie is funktionele behandeling gedurende drie weken met een zwachtel, na én week immobilisatie, de behandeling van keuze. Eunktionele behandeling van intra-articulaire frakturen heeft geen voordeel boven conventionele gipsspalk behandeling. Voor Samlento's funktionele behandeling met een tot boven de elleboog reikende funktionele koker lijkt geen plaats te bestaan. In het algemeen zijn de voordelen van funktionele behandeling van colles frakturen boven conventionele gipsspalkbehandeling beperkt. Deze conclusie is in tegenspraak met de meeste publicaties over functionele behandeling van colles frakturen.

De door somige auteurs gerapporteerde correlatie tussen het anatomische en functionele eindresulltat kan verklaard worden uit het felt dat beide resultaten afhankelijk zijn van dezelfde initiele factor: de porspronkelijke fraktuur verplaatsing. Uit een dergelijke correlatle mag evenwel op voorhand geen oor zakelijk verband geconcludeerd worden.

Het nauwelijks aanwezige oorzakelijke verband tussen het anatomische en functionele eindresultaat staat vervolg onderzoek naar functionele behandelingsvormen met nog meer vroegtijdige beweging en funktie en daarmee met grotere kans op inferteure anatonische resultaten, niet in de weg. Echter, de uitkomsten van deze studie geven aan dat er geen behoefte is aan verder onderzoek in deze richting.

Niet de behandelingsmethode, noch het anatomische elndresultaat, mar de oorspronkelijke fraktuurverplaatsing en het optreden van complicaties zijn de belangrijkste factoren die het funktionele eindresultaat bepaLen . Van de twee laatst genoemde factoren is de oorspronkelijke fraktuurverplaatsing niet te beinvloeden. Daarom lijkt onderzoek naar de oorzaak, preventie en behandeling van complicaties een nieuwe weg die ingeslagen moet worden nar verbetering van de behandelings resultaten van een colles fraktuur letsel. 


$$
\text { * }
$$




\section{CHAPTER 11}

\section{REFERENCES}

1 Albert SH, Wohl MA, Rechtman AM.

Treatnent of the distupted radlo-ulnar jolnt.

J Bone Jolnt Surg. 45A: 1373-1381, 1963.

2 Alffram PA, Bater GCH.

Epidentology of fractures of the forarn.

I Bone Jolnt Surg 44A: 105-114, 1962.

3 American Acadeny of Orthopaedic Surgeons.

wolnt Motton: wethod of reasuring and recording.

Livingstone, Edinburgh, 1965.

4 Anderson LD.

Compression plate fixation and the elfect of different types of Internal fixation on fracture healling.

J Bome Jolnt Surg 47A: 191-208, 1965.

5 Anderson R, $O^{\prime}$ Nell $G$.

Comminuted fractures of the distal end of the radius.

surg Gynecol obster $78: 434-440,1944$.

6 Andrews $\mathrm{JG}$, Youm $\mathrm{Y}$.

A blomechanical investlgation of wrist kinematlcs.

$\mathrm{J}$ BH. Omechand.cs $12: 83-93,1979$.

7 Ascher $1 R$, Bltimel 6.

Zum Krankheltgbild der Siadeck" schen Dystrophle.

Fortschr Hed 99: $712-720,1980$.

8. Augustine FW.

The colles fracture.

Missourt Mediclme 69: 421-426, 1972 .

9 Bacorn RW, Kurtzke JF.

Colles fracture. A study of two thousand cases form the New Yark State Workment s Compensation Bard.

J Bone Jolnt Surg 35A: 643-658, 1953 .

10 Baltensperger A.

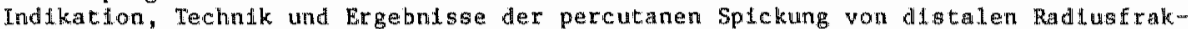
turen.

Hefte Unfalltellkde $245-247,1965$.

I 1 Bartam JR.

Views and treatment of an Important Injury of the Wrist.

Med Examlner $1: 365-368,1838$.

12 Bare JT.

Apparatus for use in reduction and fixation of fractures of distal radlus.

Cl. In orthop 6.3: 190-195, 1969.

13 Baugartl F, Kremer $K$, Schrelber $H$.

Spezlelle Chlrurgle fur die Praxis.

Georg Thieme Verlag, stuttgart, 1976.

14 Bechtol CO.

The use of a dymanometer with adjustable handle spaclngs.

J Bone Jolnt Surg 36A: 820-832, 1954 .

$15 \mathrm{Be} 11 \mathrm{Ml}$.

Pertlunar distocation of the carpus and an associated colles fracture.

The Hand 15: $262-266,1983$.

16 Betts GW, Hodgkinson $V$, Densley GW, Kamat $s$.

Origlnal Brittsch trials on the functional bractng of colles fractures.

Nursing times, May: 901-909, 1981.

17 Bll thert-Toft $M$, Kaalland Jensen $H$.

Colles fracture tratced wh modifled Bohler technlque

Acta orthop Scand 42: 45-57, 1971 .

15 Boegil $\mathrm{S}$, Chamay

Der Fuxateur externe von Hoffoun in der Behandlung won Pouteau-Colle frakturen. z Unfallmed Beruf akr 73: 159-160, 1980. 
19 Batler.

Gelenknatre Frakturen des Unterarmes.

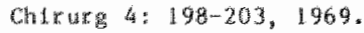

20 Büblet 1.

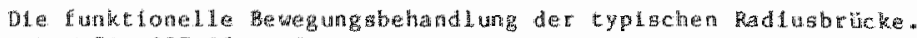

H H $70.387-390,1923$.

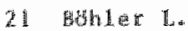

Dis Techalk der Rochenbtuchbehand lung.

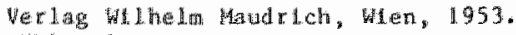

22 buler L.

The textatent of fractures. 5 th ed.

Grune stratcon, Kew York, 1956.

23 goun: $\$$

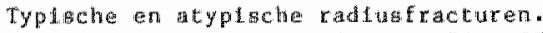

Ned Pidscht Geneesk $114: 368-374,1970$.

24 Hrady LP.

Double Pla Fixation of Severely Comminuted Fractures of the Distal Radius and una. Sostrin Med \& 56: 307-311, 1963.

25 Bultitude M, Wellwood JM, Hollingsworth R.P.

Iatravenous diazepan: Its use lin the reduction of fractures of the lower end of the radting .

Injury 4: $249-253,1972$.

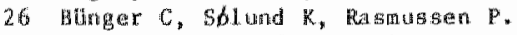

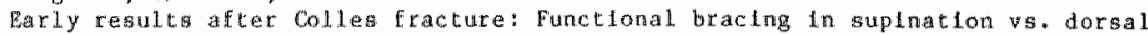

plaster lomobllization.

Arch Orthop Trauma Surg 103:251-256, 1984 .

27 Bunnedis.

surgery of the Hand. 5 th ed.

Llppincote Company, 1970.

28 Callitet $\mathrm{R}$.

Hand Patn and inpatrone.

Daw 1 Company, Philladelphia, 1982.

29 Carothers aro, Futnding DD.

Colles Fracture.

Arn J Surg * 80:626, 1950 .

30 Cassebatun wh.

Colles Fracture, a study of end results.

J A A 11:963-965, 1950.

31 Castating $I_{\text {. }}$

Les fractures rếcentes de 1 'extrómite inferteare du radius chez l'adulte.

Rev ChIt Orthop 50:581-696, 1964 .

32 Cautilly RA, Joyce kf, Gordon E, Juarez R.

Clasifictions of Fractures of the Distall Radius.

Chitn orthop 103: 163-166, 1974.

33 Cavlate $Y$.

Er ahrungen bel funktonaller Theraple von colles-frakturen mach Sarmlento.

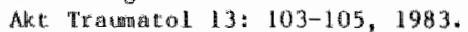

34 Charnday.

The closed treatmont of comon fractures.

Churchill Livingstone, London, 1972.

35 Cilincey G.

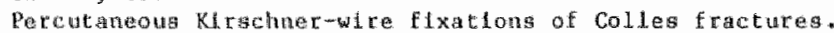

I Brothe JoLnt Surg 66t: 1008-1014, 1984

36 Cole Jil, obletz Bis.

Comothutad fracturea of the distal end of the radius tremted by skeletal transfixion

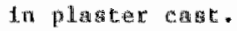

3 Bone Jolnt Sang $484: 931-945,1966$.

37 Collert s, Lsaeson $J$.

Management of redislocated colles fractures.

Clin Orthop 135: 183-186, 1978 .

38 Colles $A$.

On the fracture of the carpal extrentity of the radius .

thinburgh medical and surgichl fournal $10 ; 182-186,1814$.

39 Comter J., Auferay Y, Creyssel. J.

Le taltement chicurgicall apres behec du trattement non sanglant dans les fractures de

Lextremer Inferieure du radiug.

Acka or thop be 1 g 34: $505 \times 522,1968$. 
40 Comtet MJ., Aufray $\mathrm{X}$.

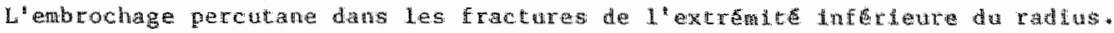

Lyon Medical 220: $309-312,1968$.

41 Conwell HE, Wesely Do.

Fractures of the distal radius in etults.

Clin orthop 83: 13-16, 1972.

42 Conwell HE.

Injuries to the wist.

Cilinical Symposia (CIBA) $22: 2-30,1970$.

43 Cooney he, Linscheid RL, Dobyns JH.

Excernal pin fixation for unstable colles fractures.

J Bone Jaint Surg 6lA: 840-845, 1978.

44 Cooney We, Dobyns JH, Linscheld $\mathbb{R}$.

Complications of calles fractures.

J Bone Jaint Surg 62A: 613-6L, 1980.

45 Cotion $\mathrm{FJ}$.

The pathology of fracture of the lower extremity of the racius.

Ann Surg. 32: 194-218, 1900.

46 Crenshaw AH.

Campbell's operative orthopaedics.

5th Ed. Mosby Company St. Louts, 1971 .

4.7 Debrunner Al.

Distale Radusfrakturen.

Schwelz Med Wochenschr 25: $820-822,1967$.

48 Denark van RE, Cotcon GIW.

Translocation temorraphy of the extensor pollicis longus after spontanens rupture di Colles fracture.

Clin Orthop 31: 106-109, 1963.

491 Denman EE.

Rupture of the extensor pollicis longus, a crush injury.

The Hand 11: 295-298, 1979.

50 DePalma AF"

Comminuted fractures of the distal end of the radius treated by ulnar pinning.

J Bone Jolnt Surg 344: 6.51-662, 1952 .

51 Destot E, Gallois E.

Recherches physiologiques et expérimentalles sur les fractures de l'extrénite

inferteure du radius.

Rev Chit(Paris) 18: 886-915, 1898.

52 Dingman PVC.

Resection of the distal end of the ulnar (Darrach operation).

J Bone Jolut Surg 34a: 893-900, 1952,

53 Dinley RJ, Michelinakis E.

Local anaeshesia in the reduction of colles fracture.

Injury $4: 345-346,1973$.

54 lobyns $3 \mathrm{H}$, Linscheid RL.

Carpal bore injuries.

C1in or thop $149: 2-3,1980$.

55 Dobyns JH, whincheid RL.

Fraceures and dislocations of the wrtst.

In: Rockwood AA, Green DP.

Fractures, Lipplneact, Philadelipha, 1975 m

56 Dowling $\mathbb{J}$, Samyer $B$.

Comminted colles fractures.

I Bone Jolnt Surg $43 \mathrm{~A}: 657-668,1961$.

57 Dunninghats TH.

The treatment of Sudeck's atrophy in the upper 11 mb by symathetc blockade.

Injury 12: 139-1/44, 1980 .

58 Ebe 1 .

Eine Methode zur Bebandlung stark versehobener Spedehenbriche an typlacher stelle.

Msche Unfallhellik 75: 375-378, 1972.

59 Ehalt w

DHe Bruchenformen an unteren Fnde de: Vorderarmbriche.

Chirurg 3: 1050, 1931 .

60 Ekenstan $F$, Hagert $C G$.

The distal radta ulnar Joint. The influence of geometry on whulated colleb fractures. Scand J Plast Reconstr Surgi $19: 27-31,1985$. 


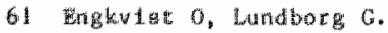

Nupture of the extensor 11 lats longugendon after fracture of the lower end of the

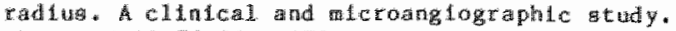

The Hard $11: 76-86,1979$.

6.2 Fondey Jhe

Fractures and attolocations about the wrist.

Sinirg: Clin an $37: 19-40,1957$.

63 Falch JA.

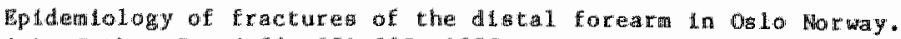

Acta Orthop scand 54: 291-295, 1983.

64 Falck Barto P.

Left- bided cirpal tunnel 1 yndrome in butchers.

Scand 3 Mork ent 4 ron health $9: 291-297,1983$.

65 Fermandez DL.

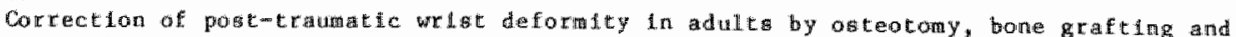
intertal foution.

J Bone Jolnt Surg 64A: $1164-1178,1982$.

66 Fisk om.

An overvilew of injurleg of the write

CLIn Orthop 149:137-144, 1980 .

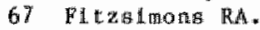

Colles"s fracture and chauffeur" s fracture.

Be Hed J 2: $357-360,1938$.

68 PIL

Had Surgery, $2 \mathrm{nd}$ Ed.

The W11lans and Wiking Company, Baltimote, 1966.

69 Torgon H, Mammel E.

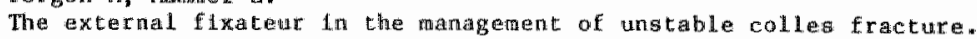

Int orthop $5: 9-14,1981$.

70. Freund $\mathbb{E}$, Whttner H, Sicheder H.

Horbus Sudeck als Kompllikation des Radiusfrakeur.

Hschr Unfallhellk 73: 569-574, 1970.

J1 Frtberg S, Lund atorä B.

Radtographlc measurements of the radlomatcal jolnt in normal adults.

Acta Radiologlca Dlagnosis 17: 249w256, 1976.

72. Fitsche $K$,

Konservative oder operattwe Theraple der typlschen Radiusfraktur?

Zentralb1 Chlr 103: $435-438,1978$.

73 Frykman o.

Fracture of the distal radius including sequelda-sinoulder-hand-fingers syndrome,

disturbance in the distal radio-ulnar jolnt and impairment of nerwe function.

Acta Orthop Seand supp. 108, 1967.

74 Gartland $3 J$, Werley $\mathrm{CH}$.

Evaluation of healed colldes fractures.

J Bong Jolnt Surg 33A: $959-907,1951$.

75 Gelbertan RH, Szabo RM, Mortengen Ww.

Carpal cumol pressures and wrist posteton in patients with colles fractures.

J Traunis $24: 747-749,1984$.

76 Colden $\mathrm{GN}$.

Treatment and prognos 1 of Colles fractures.

lancet, 511-515, warch 1963.

77 coodwin FC, Cameron DN.

keduction of the permanent partial diablilty of commuted fractures of the lower ead of the radlus by skeletal traction.

Surig Gymecol obstet 75: $343-344,1942$.

78 Corle RIA, Dongen LMv, Winters HAM.

Treatment of Sudeck" dystrophy wh hydroxyl radical scavengers.

20 h Congress Ruropean Soctety for Surglcal Research, Rotcordam, 1985.

79 Green Dp.

Plns and plaster treatment of commuced fractures of the distal end of the radius.

J Bora Joint Surg 57A: 304-310, 1975 .

80 Green IT, Gay FH.

Colles Exacture, residual disability.

Am J Surg $21: 636-642,1956$.

81 Gulde to the evaluation of permanent fmpalrment of the extrentiles and back.

JA A (spectal edition) 166: 1958 . 


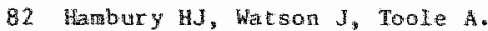

The use of differential skin-temperature measurements in the evaluaton ot postratatic odema control.

Med Biol Eng 13: 202-208, 1975 .

83 Hamand $G$.

Comminuted colles fractures.

Aar I Surg $78: 617-624,1949$.

84 Hakins LG, Storey SD, Wells GG.

Intravenous lodocalne anesthesta for upper extrentty fractures and dalocatlons.

$J$ Bone Jolnt Surg 52A: $1647-1649,1970$.

85 Hetfington CA, Thompson RC.

The use of laterscalent black anesthesia for mantpulative reducion of tractures ant dislocations of the upper extrentities.

J Bone Jolnt Surg 55A: 83-86, 1973 .

86 Heppenstall RB.

Fracture treatment and healing.

W. B. Saunders Company, Philadel phia, 1980.

87 Hindimg E.

Fractures of the distal end of the forearm.

Acta Orthop Scand 43: 357-365, 1972.

88 Hudson OC, Rusnack T.l.

Comblnted fractures of the lower end of the radius.

An J Surg. 95: 74-80, 1958.

89 Huffstadt AJC, Edsma WH.

De Hand, stafleu, Ahen an de Rijn, 1982 *

90 Imanue $1 \mathrm{HM}$, Levy Fl, Geldwert $\mathrm{J}$.

Sudeck" \& Atrophy: A review of the it iterature.

$J$ poot Surg 20: 243-246, 1981 .

91 Jakob RP, Fernandez DL.

The treatment of wrist fractures whth the small A.0. Extermal fixaton dewloe.

Current Concepts of External Ftxation of Fractures.

Springer-Verlag, herlin, 1982 *

92 Johnsson $\mathrm{U}$.

External fixation for redislocated colles fractures.

Acta Orthop Scand $54: 878-883,1983$.

93 Jöreskog KG, Sỏrbon D.

LISREL WI, Analysis or Iinear structural relatlonships by the method of maxtmum

1.kelthood.

3e ad., Unlversity of Uppsala, 1984.

94 Kapand 1 . A.

L'Ogteosynthe par double embrochage intra-focal.

Ann Chit 30: 903-908, 1976.

95 Kapand 11 IA.

The phystology of the joints.

Church111 Liwdagstone 2e ed, , Edlnburgh, 1970.

96 Kaplan $\mathbb{E B}$.

Functlonal and Surgleal Aratomy of the hand.

Second Ed, Llpptncott Company, London, 1965.

97 Katuer JMG.

Functional arratomy of the wrist.

Cllin Orttiop 149:9-19, 1980 .

98 Keeman H.

External fuxation of distal radial fractures. Technique and result. sympostum

Fractures and dislocattons around the wrist, Ainterdan, 1984.

99 Kellsey JL.

Eptdemtology of musculo skeletal disorders.

In: Monolgraphs in eptdeniology and blostatistios vol 3.

Oxford university press, New York, 1982.

100 Kessler 1 , Hechi 0 .

Present application of the Darrach Procedure

Clin orthop 72: 254-260, 1970.

101 KInley DL, Evarts CH.

Carpal tunnel syndrome due to a small displaced fragnent of bone.

clewe Clin Q 35: 215-221, 1968.

102 Kirkpatrick JE.

Evaluation of Gitp loss.

Callfornta Mediclne 85: 314-320, 1956. 
103 Horap the

Tretentent of wowe combleations of colles fracture.

I $A M A$ I. $48: 25 \%-527,1952$.

104 Kollaed H.

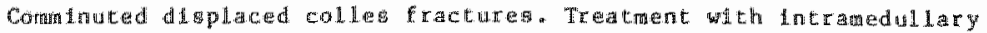

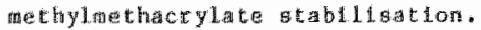

Heta Orthop Scand 54:307-31, 1983.

$105 \mathrm{Kr}$ istangen $\mathrm{A}$.

Colles fracture operacdure treatment indicatons and results.

Acta orthop seand 39: 37-46, 1968.

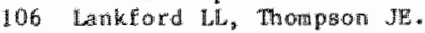

Reflex symachetic dyetrophy, upper and lower extremity: diagnosis and mangement, Instructonal Cours luetures 25: 169-178, 1977.

107 Late Lili, Sarmiento t, Tare Rr.

The teational of functional bracting of fractures

Clin orthop $146: 28-26,1980$.

108 Ledoux $A$.

La consolidation en postition vicleuse des fractures de l'extremter inferteure du radius.

Act Chir Belg 7: 477-502, 1969 .

109 Lldatrom A.

Fractures of the distal end of the radius.

Acta orthop Scand suppl 4 l, 1959.

110 Liles R, Frierion JN, Wolf CL, Frnka th.

Reduction of Collea Fracture by welght traction nder local anaesthesta.

Sonth Med J 62: 45-48, 1962.

111 Lithenfeldt A.

Uber dLe Er zengung der typlschen Verletzungen der Handwurzel knochen der Radusbruches.

2 orthop thit $20: 437-454,1908$.

112 Linden wan der, Erteson $\mathrm{R}$.

Colleg fracture.

$J$ Bone JoInt Surg 63A: $1285-1288,1981$.

LII Litppian RR.

Laxity of the rado-ulnar folmt following colles fracture.

Areh Surg 35: 772-782, 1937 .

11.4 Lloyd GJ, Stangel L.

The power of pronation and supination followlng colles ftacture.

Phys lotherapy Canada 26: $13-16,1974$.

115 Lucas GL, Sachtjen BH.

An analysils of hand function in patlents with colles fracture, treated by rush rod fixat lor.

C1In Orthop 155: 172-179, 1981.

16 Lugnegard 11.

Resection of the head of the ulna in postratuatic dysfunction of the distal

radilomilinar jotnt.

Scand J Pagk Reconger Surg 3:"65-69, 1969.

117 Lymol AC, Lif pscomb PR.

The catpal tunnel sydrome ard colles fracture.

IA A A $185: 363-366,1963$.

11.8. Mackay 1 , simpson Rro.

Closed rupture of extensor dlgitorum comung tendon following fracture of the radius.

The Hand 12: $214-216,1980$.

1.9 Makal $\mathrm{F}$, Khand $\mathrm{J}$.

orlig at the carpal tunnel syndrome followh colles fracture.

Acta ChIr Orthop Chechoslovacs 36: 52-58, 1969.

120 Mande 1 L $\mathrm{BB}$.

Asessment of results of treatment of 100 cases of colles fracture.

South Afrte ked $J 39: 171-174,1965$.

121 Mareh HO, Teal SW.

Treatmete of cominuted fractures of the distal radius wh self-contained skeletal

traction.

Aim J Sur $124: 715-719,1972$.

122 Marti R polowskt W.

Distal, radial. fractures, results of internal flution.

Sympostum Fractures and dislocations around the urlsit.

Ansterdam, 1984.

123 Mson ML.

Colles's fracture. A survey of endmresults.

Brtt J Surg 15: 340-346, 1953. 
124 Matzen PF.

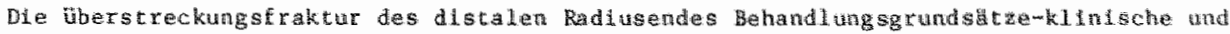
röntgenologil sche Ergebalsse.

Beitr Orthop Traturatol $28: 106-109,1981$.

125 Natthews LS.

Acute valar compartment syndrome secondary to distal radis fracture 1 m athlete Am $J$ o S L L : 6-7, 1983 .

126 Mayer JH,

Colles's Fracture.

Brit J Surg 27:629-642, 1940 .

127 Mayfield JK, Johnson RP, Ki lcoyne RF.

The 1 dgaments of the human wrtist and thelr functional signiflcance.

Anat Rec 186: 417-428, 1976 .

128 Mc Bride ED.

Disability exalluation.

5 th Ed, Lippincot Company, Fhiladelphia, 1953.

129 Mrobin B.

The btology of fracture healing in long bones.

$J$ Bone Jo1nt Surg 60B: $150-162,1978$.

$\$ 30$ McLearde $M$.

Letcer tot the editor

Iajury 5: 358,1974 .

131 Milich 11.

Torstonal mallalignments in transwerse fractures of the lower end of the radlua.

Surgery 5.5: $396-406,1964$.

132. Miller BN.

Simultaneous fracture of the carpal scaphold and adjacent bones.

The Hand $15: 258-261,1983$.

133 Müller $M$, Polgenfürst $J$, Zaumbauer $F$.

Karpaltumel syndrom mach Spetchembruch an typlscher stelle.

Unf all he 11 kunde $79: 389-394,1976$.

134 Nemethi CE.

Normal wrist motlons.

Industrlal Mediclne and Surg 22: 230, 1953.

135. Wewton-John HE, Morgan DB.

The loss of bone wlth age, osteoporosis and fractures.

c.th orthop 71: 229-252, 1970.

136. Nigst H.

2ur propiylaxe der postraumatischen osteoporose und dea Sudeckschen Syndrons.

Der Landartz 43: 167-169, 1967 .

137 Nikolid $V$, Hancevie $J$, Hudec $M$, Banovie

Absorption of the Impact energy in the paimar soft tissues.

Anat Enbryol 148: 215-221, 1975.

136 Okuhara

Spontaneous rupture of flexor tendons of at litle finger dua to profecton ot the hook of the hamate.

The Hend $14: 71-74,1982$.

139 OLder TH, Stabler gV, Casseban WH.

Colles fracture: ewaluaclon and gelectlon of therapy.

J Trauma 5: $4469-476,1965$.

140 Patrick J.

A study of supination and pronation whth espectal reference to the treatment of

forearm fractures.

J Bone Jolnt Surg: 28: 737-748, 1946.

141 Pasilla M, Karaharju EO, Leplote PV.

Rolle of phystcal therapy in recovery of function after colled practure.

Arch Phys Med Rehabl1 55: $130-134,1974$.

142 Perdieus H, Segherg $K$, van Rtet B.

Behandeling van de pollstrakturr.

Act Chit Belg 32: 6.5-82, 1966.

143 Pollack HJ von, Mermann R, Eollack E.

M. Siudeck und Psyche.

Beltr orthop Tramatol 27: $4633^{-468}, 1990$.

144 Pool C.

Colles's Fracture, A prospective study of treatment.

$J$ Bone Jolnt Surg 558: 540-544, 1973 . 
14.5 Pouteral

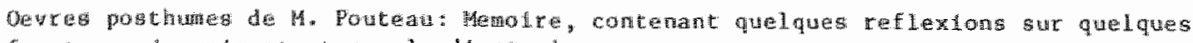
fracures du polgnet et wur le diatasig

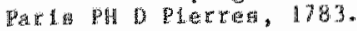

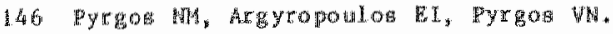

The use of Intravenous eglonal anathesia for the reduction of Colles' fractures. Reguactiation $5: 59 \mathrm{~m} 63,1976$

147 Reifenesten EC.

The chationshpo of steroud homones to the development and the management of

osteoporosis in agling preople.

Clith Orthop 10:206-253, 1957 .

148 Rlctiter D.

Behand lurgergebnlage bed typlechen Hadustrakturen nach Elnfuhrung von

"Grupenturnen".

betrache Gesundhe Ltsiegen 21: 1983 m $1986,1966$.

1.4.9 kobblat H.

Anatomical study of the median merve in the carpal tunnel and etiologies of the carpal

Eungel sydrone.

J sone doint Surg 45A: $953-966$, 1963 .

150 Rogers $\mathrm{SC}$.

An andilysts of Colles'g fracture.

Bet th Hed J $\mathbb{1}: 807-809,1944$.

151 Rosetzisiky A.

Colles Fractureg treated by plister and polyurethane braces: a controlled clintcal

stidy.

J Tranturat 22: $910-913,1982$.

152 Rublinowich RM, Rennle WR.

Colles fracture: End regults en relation to radiologlc parameters.

Cara J Sur $26: 361-366,1983$.

153 Rusth liv, Rush HL.

Evolution of medullary flkation of fractures by the longtudinal pin.

An J Surg 78: 324-333, 1949 .

154 Riş LV.

Cloged medullary plnntag of Colles fracture.

Clin orthop 3: $152-162,1954$.

155 Ryckak 35 , kalenak. A.

In fury to the median and ulnar nerves secondary to fracture of the radius,

J Bone Jolnt Surg 59: 4j:4, 1977 .

156 Sadr B.

Sequential rupture of extensor tendons after a colles fracture.

J Hand Surg 9A: $144-145,1984$.

157 Salter $N$, Darcus HD.

The anplitude of forearm and of humerat rotation.

J Anat 87: 407-418, 1.953 .

159 Sintentento $A$.

The brachtoradialls a a teforming force in Colles fractures.

clin orthop $38: 86-92,1965$.

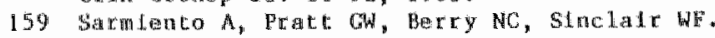

colles fracture, functional bracing in buptnation.

J Bone Jolnt Surg. $57 \mathrm{~A}: 311-316,1975$.

160 Sarmiento A, Stnclatr Wr.

Fuacure orthoses in "At las of orthostcs, blomechandcal princlples and application".

Ste. Lould Mosby, 245-254, 1975 .

161 Sacindento $A$, Schaefer JF, Beckerman $\mathbb{L}$, Latte LL, Enis JF.

Fracture healing in tat fetora as afected by functond welght-bearing.

J Bone Jolut: Surg 59A: 369-375, 1977.

162 Samitento $A$, zagorskl jB, sinelalr wF.

functonal bracing of Colles fractures: A prospective study of tmobllizition lin suplnatlon ve pronation.

Clin orthop $146: 175-183,1980$.

163 Sarmiento A, Latra LL.

Cloned functional trattment of fractures.

Sprlager Verlag, Berlin, 1981 .

164. Sellueck th.

Long-term follow-up of treatment of comminuted fractures of the distal end of the radius by traws fxation whth Kirschner wires and cast.

J Bone Jolnt Surg $44 \mathrm{~A}: 337-351,1962$. 
165 Schnelder Lh, Rosenstein RG.

Restoration of extensor pollicis longus function by tendon tranger.

Plast Reconstr Surg 71: $533-537,1983$.

166 Sehoen JL, Mared RK.

Correction of malunions of the radius.

Sympositu Fractures and dislocations around the rat.

Arsterdan, 1984.

167 Scote IH.

Cominuted colles fractures: Their treatment by sheletal plnnlag and axternal

ilixation.

I Int Col1 Surg. 4 具: $521-526,1964$.

168 Slegel RS, Welden $\mathbb{I}$.

Combined median and ulnar nerve lestons complicating fractures on the diatal radis and ulna.

J Trama $8: 1114-1118,1968$.

169 Sirbu AB, Colloff B.

Colles fracture. A study of and results with conservatwe mangement.

W $J$ or $S$ o G. 59:635-643, 1951.

170 Smail GB.

Long-terta follow-up of Colles"s Fracture.

J Bone Jolnt Surg 478 : $80-85,1965$.

171 Satith FM,

Late rupture of extensor pollicus longus tendon followling Colles's fracturem

$J$ Bone Joint Surg 28: 49-59, 1946.

172 Solund $K$, Rasmussen $P$, Borg $L$, Bunger $C$.

Radiologish, funktonel og soclal heling efter collex fraktur.

Ugeskr Laeger 145: 2289-2292, 1983.

173 Soren A.

Treatment of Colles" fractures.

Medical Times 93: 1283-1286, 1965.

174 Southrayd Wh, Millender LH, Nelebuff EA.

Rupture of the flexor tendons of the ladex fliger after colles" Fracture.

J Bone Jolnt Surg $57 \mathrm{~A}: 562-563,1975$.

175 Spira $\mathrm{E}$, Weigl $\mathrm{K}$.

The comminuted fracture of the $1 \mathrm{sta}$ t end at the radius.

Reconstr Surg Traukat 11: 128-138, 1969.

176 Sponsel KH, Palm ET.

Carpal tunnel syndrome following Colles fracture.

Surg Gynecol obstet 100: 1252-1256, 1965.

177 Stapere JWJL. (DWNI)

Personel communication

Maastricht, 1982 .

178 Stewart $H D$, Innes $A R$, Burke $F D$.

Functional cast bracing for colles fractures.

$J$ Bone Jolnt Surg 668: 749-753, 1984 .

179 Stewark HD, Imnes AR, Burke FD.

The hand complfcations of colles fractures.

I hand Surg 10B: 103-106, 1985.

180 Stewart HD, Inneg AR, Burke FD.

Factors affectlng the outcome of colles ficture: an anatondcal and functonal gtudy.

Injury 16:289-295, 1985 .

181 Strande11 $G$.

Post-tratuatc rupture of the extensor polllels longug tendon - Pathogenegla and treatment.

Acta Chir scand 109: 81-96, 1955*

182 Strong $\mathrm{M}$.

Treatment of Colles fractures.

Surg Gynecol Obstet 121: 107-112, 1955.

183 Sturra G.

Beltrag zur Anatomie deg typischen Radiusbruches. Radlometrische Unterouchungen.

Anat Anz Bd 125: 1-17, 1969.

184 Swanson $\mathrm{AB}$.

Inplant arthroplasty for disabilities of the distal radiomulnar folnt.

orthop CII N N 4: $373-382,1973$.

185 Swanson $A B$, Góran-Hagert $C$, de Groot-Swanon 6 .

Evaluation in:

Hunter M, Schnelder LH, Hackln EJ, Bell JA.

Rehabilltation of the hand, 62-69, Mosby Company, Saint Louls, 1978. 


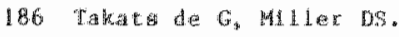

posteraumate dyetropty of the extrenteles.

Aretin surg. $46: 464-479,1943$.

187 Taylor Go, Parsons Ci.

The role of the dicus articularts in colles fracture.

I Bone Jolnt Surg 20: 149-152, 1938.

188 Vatagh-Jacken 0 月.

Rupture of extensor tendons by actitor at the infertor radiomlnat joint.

I Bone Jolnt Surg 30B: $528-530,1948$.

$199 \mathrm{VoLz} \mathrm{RC}$, Lleb $\mathrm{H}_{7}$ Berdarin d.

Blomechanics of the wrist.

clin orthop 149: 112-117, 1980.

190 Wahlerom 0.

Treatimentio of colles fracture.

Acta Orthop Scand $53: 225-228,1982$.

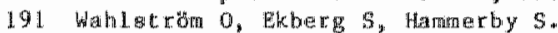

Sertal bone scanning of colleg fracture.

Arch Orthop Trauma Surg 102: 11-17, 1983.

192 Wation-Jones

Fractures and jolnt lajurtes.

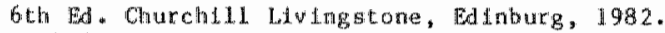

193 Whithe $K$.

RadLus Korrektult Operationen.

Fortsch Hed 101: 295-302, 1983.

194 withelm.

Dhe Ruptur der langen Datumenstecksehne.

Handchirurgte $12: 37-38,1980$.

195 Welgl $\mathrm{K}$, Splra E.

The trlagular flbrocartlage of the wrist jolnt.

Reconster Surg Traumatol 11: 139-153, 1969.

196 Weyand $\mathrm{F}$, Weller $\mathrm{S}$, Benning $\mathrm{CD}$.

Uber den zusammenhang won funktioneliten Rirgebnis und primaren Repostcton bel typtschen

Rad tusf rakturen.

Med Welc 40: 2361-2363, 1967 .

197 WLeringen AM van.

Prospective study conservative/operative treatment of Colles fractures.

Sympostum Fractures and dislocations around the wrist.

Amsterdam, 1984 .

198 Whter $H$.

Ruptur det Sehne des Musculls Extensor Pollicls Longus als Komplikation der

Rud lusfraktur.

Beitr K1.1n Chir 201: $4488-452,1960$ *

199 Wong Frlt, Pho RWH.

Madian nerve compression, th thendon ruptures, after colles fracture.

$J$ fland surg 9B: $139-141$, 1984 .

200 Youm Y, Flate Al:.

Kingmatice of the wrist.

C.11n op thop 149:21-32, 1980 .

201 Youm $Y$, McMurty RY, Flatt Al, Glllesple TE.

Kinemat hos of the wits.

Expertantent study of tadlo-ulnar dewtation and flextonmextengion.

$\mathrm{J}$ Bone Jolnt surg 60A: 423-431, 1978.

202 zitumeran KW.

Acute compactment gydrome of lower arw and hand. Prevention and treatment by surglcal decompression?

Symposturit Fractures and dislocations around the wrist.

Ansterdam, 1984 .

203 zodga H.

firtcure of the lower end of the radiug with ulnar nerve palsy.

J Bone Jolnt Surg 48B: $516_{A}-516,1966$. 


\section{CHAPTER 12}

\section{ADDENDA}

Axdendur 1

Information for the patient.

(a11 patients)

Mou have got a plaster because of a wrist fracture The plaster is necessaty for proper healing of the fracture. The first day your hand whith show some swelling which is norral. Important:

- Keep your arn la a sling during the day for the flrst thee days.

- Keep your arm elevated on a cushion during the might for the first three days.

Return to the casualty department innediacely,

- if the hand beconies numb, blue or whice, or swielis consderably.

- If pain increases much.

An appointment is made for plaster check up after one day subsequent appointments for check up wil be made thereupon.

Stop using the siling after three days. Exercise finger and shoulder movements freguently during the day.

In case of complaints or questions you may contact the casuley department, telephone number 043 am 862059 .

\section{Addendum 2}

Information for the patient.

(brace treatment)

You have got a brace because of a wrist fracture. This brace enableg you to perfora exercises th the arm and hand. Exerclses and motion are good for heallng of the fracture and prevent stiffness of the hand. Keep your hand and wrist moving as often as posstble during the day. Stretch the flingers and make a fist alternatively. Rotate your hand an far as posstbile, however prevent pain.

Or:

Information for the patient.

(bandage treatment)

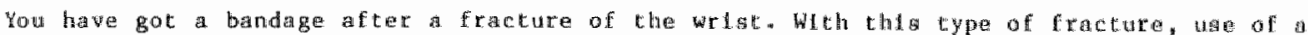
plaster cast durlng one wek is suffichent. After that, a bandige gueg enough aupport.

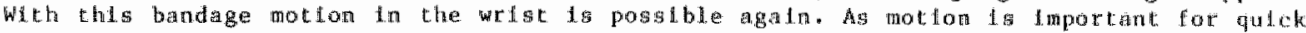

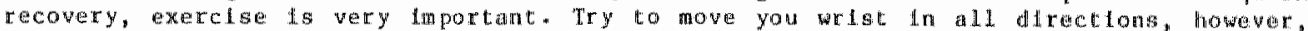
prevent paln. Some s 1 ight disconfort is normal.

The fracture (crack) has mot healed yet. Prevent lifting, carrytng, pughing or pulling. Light dally work activittes, dressing, eatilng or knlting are permithed.

The bandage 1 s necessary durdng three weeks.

Addend un 3

Information for the patient.

(all patentens)

You have had a wist fracture. The plaster, brace or bandage has been removed. For a fast recovery, exercises wh the wrist and hand are very 1 mportant. Tibe best lo to akerclse lin Lukewarn watex. Rotate the wist as when stirring, move 1 tup and down, to che right and to the left. Extend the fingers and make a fist altermately, gqueeze out g gponge under water. Try to increase the excursilons every day.

Exerclse at least six times day durlng a quarter of an hour.

Wringling, heavy lifting or sport should be postponed untell a month aftar retnoval of the plaster, brace or bandage. 
Addenduri 4 Tyo way andyolis of variance of the functional recovery

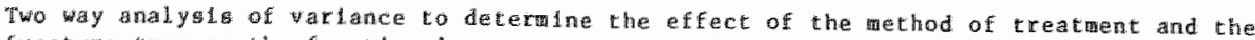
fracture type on the functional recovery. Hean and standard deviation of the square root of the functional regult score at the oubseguent checkpoints are presenced for each treatremt sroup and for each fracture type (T1, T2, T3, T4). The scores were square root transtoraed

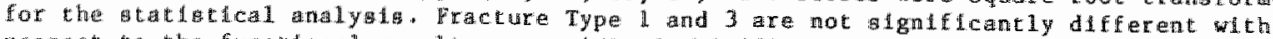
rexpet to the functional regult scores (T1-T3 $>0.05)$.

\begin{tabular}{|c|c|c|c|c|c|c|c|c|}
\hline & & week & 4. & 6 & 10 & 14 & 26 & 52 \\
\hline \multirow[t]{8}{*}{ Gon } & \multirow[t]{2}{*}{$\mathrm{T} 1$} & mean & 5.55 & 4.42 & 3.21 & 3.14 & 2.23 & 11.62 \\
\hline & & $\mathrm{Bd}$ & 1.95 & 2.02 & 1.19 & 1.03 & 1.30 & 1.00 \\
\hline & \multirow{2}{*}{$\mathrm{r} 2$} & mean & 7.34 & 5.92 & 4.86 & 3.74 & 3.22 & $2: 46$ \\
\hline & & $\mathrm{Bd}$ & 1.80 & 1.88 & 2.02 & 1.64 & 1.42 & 1.01 \\
\hline & \multirow[t]{2}{*}{13} & Trean & 5.39 & 3.41 & 3.12 & 2.71 & 1.93 & 1,66 \\
\hline & & sd & 1.21 & 1.17 & 1.21 & 0.83 & 0.97 & 0.96 \\
\hline & \multirow[t]{2}{*}{$\mathrm{T} / 4$} & mean & 7.60 & 6.13 & 4.47 & 3.76 & 2. 916 & $2 * 66$ \\
\hline & & $s d$ & 1. 58 & 1.76 & 1.38 & 1.50 & d. .58 & $1+28$ \\
\hline \multirow[t]{8}{*}{$\triangle A R$} & \multirow[t]{2}{*}{$\mathrm{Tl}$} & mean & 4.37 & 3.38 & 2.17 & 2.37 & 11.74 & 1.42 \\
\hline & & $\Delta d$ & 0.64 & 0.72 & 1.20 & 0.76 & 0.59 & 0.68 \\
\hline & \multirow[t]{2}{*}{$\mathrm{T} 2$} & mean & 6.39 & 5.03 & 4.29 & 3.34 & 2.88 & $2 \cdot 12$ \\
\hline & & $\mathrm{Gd}$ & 1.34 & 1.19 & 1.51 & 1.59 & $\mathbb{1} .23$ & 1.17 \\
\hline & \multirow[t]{2}{*}{$\mathrm{T}$} & mean & 5.73 & 4.21 & 3.18 & 2.77 & 1.78 & 1.56 \\
\hline & & $\mathrm{sd}$ & 0.74 & 1.54 & 1.37 & 1.08 & 1.19 & 1.19 \\
\hline & \multirow[t]{2}{*}{$\mathrm{T} 4$} & mean & 7.77 & 6.03 & $5 \cdot 02$ & 4.41 & 3.58 & 2.89 \\
\hline & & $\mathrm{sd}$ & $1 \cdot 54$ & 1.72 & $1 . .96$ & 1.71 & 1.698 & 1.42 \\
\hline \multirow[t]{8}{*}{ FUW } & \multirow[t]{2}{*}{$\mathrm{Tl}$} & mean & 3.73 & 2.89 & 2.25 & 2.27 & 2.30 & 1.68 \\
\hline & & $\mathrm{sd}$ & 1.86 & 1.47 & 1.36 & 0.92 & 0.88 & 0.52 \\
\hline & \multirow[t]{2}{*}{$T^{2} 2$} & fivan & 6.41 & 5.28 & $4 \cdot 16$ & 3.35 & 2.50 & 1.75 \\
\hline & & 3d & 11.87 & 2.07 & 1.59 & 1.55 & 1.11 & 1.07 \\
\hline & \multirow[t]{2}{*}{$T 3$} & mean & 3.48 & 2.04 & 1.83 & 1.83 & 1.40 & 1.28 \\
\hline & & $5 \mathrm{dd}$ & 1.37 & 1.77 & 1.58 & 0.71 & 1.06 & 1.43 \\
\hline & \multirow[t]{2}{*}{$\mathrm{I} / 4$} & mean & 6.78 & 5.45 & 4.42 & 4.08 & 3.17 & 2.36 \\
\hline & & sd & 1.26 & 0.96 & 0.70 & 0.94 & 0.93 & 1.18 \\
\hline
\end{tabular}

Two way analysis of

warlance $\mathrm{F}-\mathrm{taest}$

\begin{tabular}{|c|c|c|c|c|c|c|c|}
\hline type-eftect & $p=$ & $0.00 *$ & $0.00 *$ & $0.00 *$ & $0.00 *$ & $0.00 *$ & $0.00 \%$ \\
\hline method-effect & $y=$ & $0.00^{*}$ & 0.02 * & 0.11 & 0.59 & 0.71 & 0.43 \\
\hline cy prameth o l nt o & $p=$ & 0.28 & 0.41 & 0.47 & 0.48 & 0.38 & 0.72 \\
\hline \multicolumn{8}{|c|}{ Contest for contrasto } \\
\hline$[1]-T^{2} 2$ & $p=$ & $0.00^{*}$ & $0.00 *$ & $0.00 *$ & $0.01 *$ & $0.00 *$ & $0.01 *$ \\
\hline $\mathbb{T}\{-\mathbb{T}\}$ & $p$ & 0.53 & 0.53 & 0.74 & 0.48 & 0.35 & 0.83 \\
\hline$T L-T 4$ & \# & $0.00 *$ & $0.00 \%$ & $0.00 *$ & $0.00 *$ & $0,00 \%$ & $0.00 *$ \\
\hline$T_{2}-T_{3}$ & $p$ & $0.00^{*}$ & $0.00 *$ & $0.00 *$ & $0.02 *$ & $0.00 *$ & 0.06 \\
\hline$n 2-144$ & $p=$ & $0.02 *$ & 0.113 & 0.48 & $0.02 *$ & 0.12 & $0.01 *$ \\
\hline $13-14$ & $p$ & 0.00 光 & $0.00 *$ & $0.00^{*}$ & $0.00 *$ & $0.00 *$ & $0.00 *$ \\
\hline $71 / 3)-72 / 4$ & $p=$ & $0.00^{*}$ & $0.00 *$ & $0.00 \%$ & $0.00 *$ & $0.00 *$ & $0.00 \%$ \\
\hline
\end{tabular}


Addendu $S$ Two way analysis of vartance of the functional end result

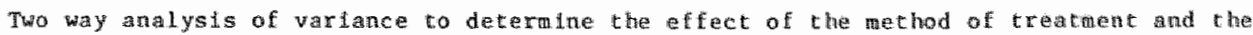
Eracture type on the functomal end result. Hean and standard deviatlon of the logatithat the functional end result score is presented for each treacment group and for each fucture type (T1, T2, T3, Th). Fracture Type l and 3 are not slgniflcantly difterent with rasect to the functional and result score (T1-T3 $p>0.05)$.

\begin{tabular}{|c|c|c|c|c|c|c|c|}
\hline & & $\mathrm{CON}$ & $\mathrm{SAR}$ & FUN & Two ray ana 1 y & ts of & \\
\hline & sean & 0.59 & 0.52 & 0.65 & typ-efect & $p=$ & $0.00 *$ \\
\hline & sd & 0.39 & 0.25 & 0.26 & te thod-effect & $p=$ & 0.6 .2 \\
\hline & mean & 0.93 & 0.85 & 0.76 & type-met $\mathrm{h}$ int. & $p=$ & 0.68 \\
\hline & sed & 0.33 & 0.41 & 0.36 & t-test for com & rastis & \\
\hline & mean & 0.67 & 0.53 & 0.45 & $T 1-12$ & $\mathrm{p}=$ & 0.00 \\
\hline & sd & 0.33 & 0.41 & 0.54 & $T 1-T$ & $\mathrm{p}=$ & 0.75 \\
\hline \multirow[t]{5}{*}{$\mathrm{T} 4$} & mean & 1.00 & 1.12 & 1.02 & $T 1-T 4$ & $\mathrm{p}=$ & $0.00 *$ \\
\hline & $\mathrm{sd}$ & 0.38 & 0.34 & 0.30 & $\mathrm{~T} 2-\mathrm{T}_{3}$ & $p=$ & $0.01 *$ \\
\hline & & & & & $12-14$ & $p=m$ & $0.00^{*}$ \\
\hline & & & & & $13-94$ & per & $0.00^{*}$ \\
\hline & & & & & $\mathrm{T} 1 / 3-\mathrm{T} 2 / 4$ & $\mathrm{p}=$ & $0.000 *$ \\
\hline
\end{tabular}




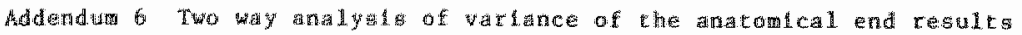

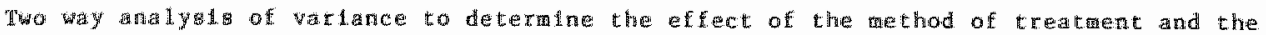

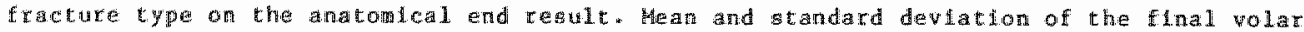

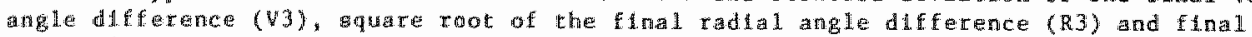
radid length difference (Lj) and of the final radial oht

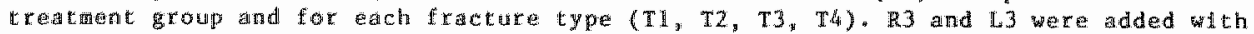

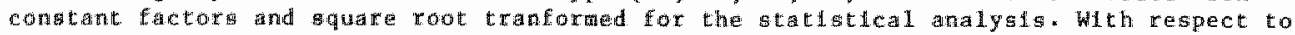

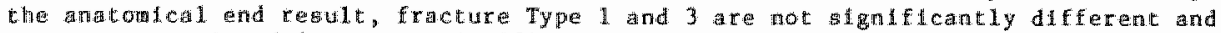

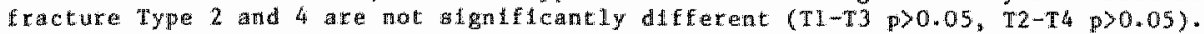

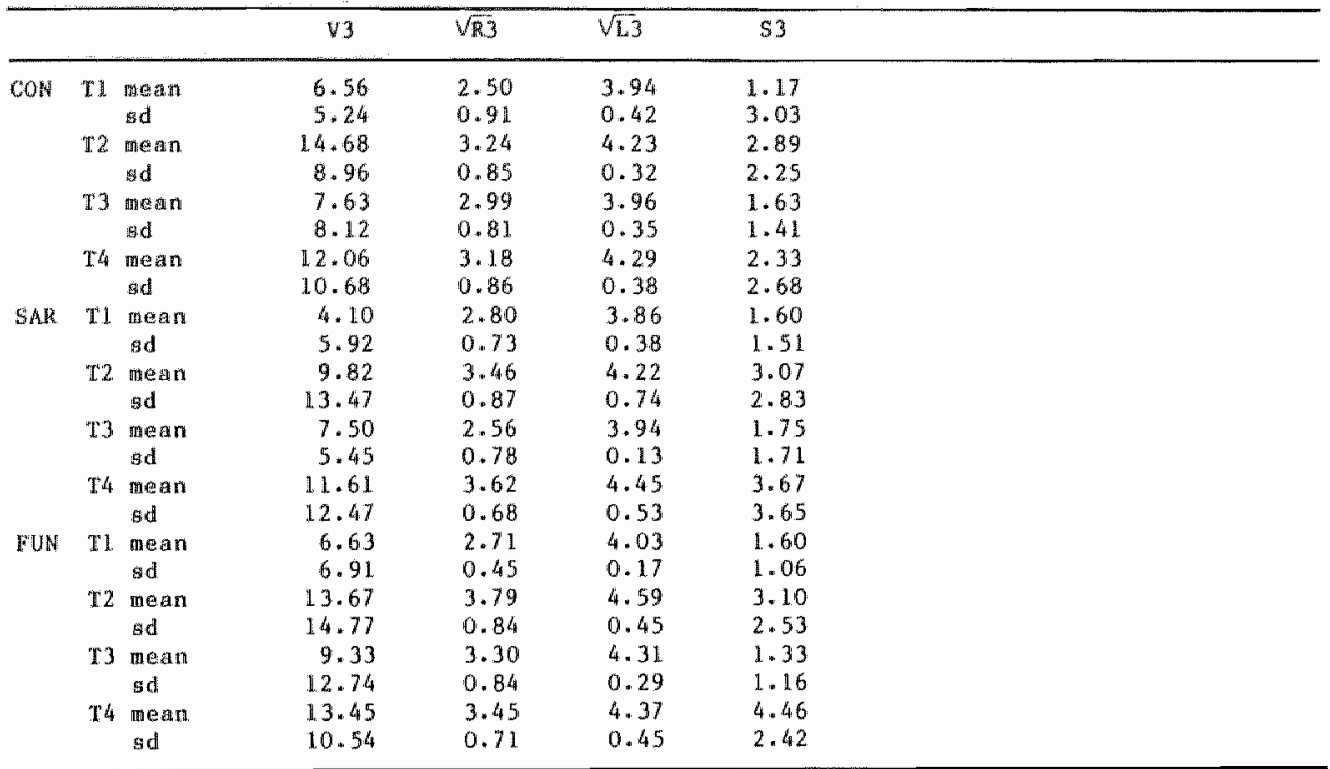

Two way analygls of

varlance Fitest

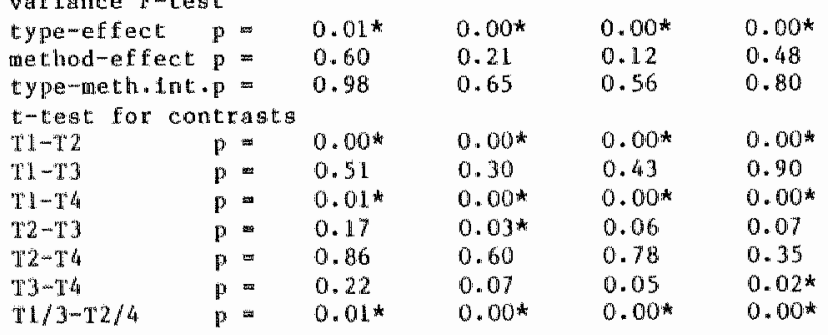


This study was performed at the Department of General Surgery (Prof. Dr. J.M. Greep) of the Undversity of Limburg, The Wetherlands.

First of all, I would like to express my sincere apprectation to all the people who have contributed to the completion of this work.

I arn specia1ly indebted to my promotor prof, Dr. Co Greep, under whom I received my surgical training. He gave me every opportunity to choose my ow direction in the surgical field. The infrastructure of the department that he created, was not only stimulating but also gave me ample opportundty to carry out this study.

I owe a great deal to Dr. Jouwert stapert. His Intial ldea developed Into this thesis. With the help of some suppositories, he kept me on the straight: and narrow.

I feel much obliged to prof. Dr. Jan Drukker. During several fruitfull evening- and night sessions he gave essentlal contributions to the design of the study. Thanks to critical remarks throughout the course of this thesis he helped to polishmup the final product.

I am very gratefull to Drs. Lex Volovics who answered all my questlons through many piles of print-outs. His expert statistical knowledge made $1 \mathrm{n}$ terpretation of the results possible.

I acknowledge with gratitude Prof. Dr. R.J.A. Goris, Prof. Dr. A.J. van der Linden and Prof. Dr. R.K. Marti for thelr critlcal revision of the manuscript and their valuable commentary.

Cees-Rein van den Hoogenband and Henk van Mameren supported very kindly this thesis with ideas and critical comments.

Coen Oosterhuts and Paul Vegt helped me a lot fin collecting the data.

Without the much appreciated help of my resident collegues, the treatment at the casualty department could never have been carried out according to the protocol.

I an much obliged to all my colleagues in Mastricht as well as in Groningen for their frilendship and support.

The technical sky11s of Eugène Ruth, Huub May and Guss Boren, resulted in masterly applied braces, splints and bandages.

I am very gratefull to Chris Voskamp for his artistlc aststance in the drawIngs, lay-out and design of the radiographtc measurement device and to Mr. J. Retz for manufacturing the rotation gonioneter.

My speclal thanks must be reserved for Lllianne Erven-Amory who rereretyped the "final" manuscrlpt in an ever lasting good mood.

Peter Robinson, FRCS: I would like to thank for his kind willingness la correcting the English.

I thank Alex de Koning, Marion de Leeuw, Sjef Roos, Frans Tan and Marcel Theunissen for their expert contribution to the statistical analyses and cor Wvers, Jo Houben and Anne-Claire Hasaart-stassen for the beautifull plctures. $I$ an gratefull to the staff of the casualty department, outpatient cilnic and $X$-ray department without whon this study would not even have started.

My respectiull appreciation goes to all the patients for thelr wlidingesg to cooperate in this study and endure all the examinations.

My sincere grattude concerns my four parents for their confidence and at 1 mulation.

Admiration goes to Xandra for her keen Instght, methodological and analytfcal. thinking and for the many hours of expert and warm listentng.

Finally, I am happy to thank Rutger and Larlssa for thefr patience. Exploring the real important things in life, they did not see the point in making all the fuss about a little booklet, and they might be right. 


\section{CURRICULUM VITAE}

Hans Peter de Bruljn was born on December 1st, 1948 in Haarlem, The Hetherlands.

He graduated from high school (Karel van Mander Lyceun, Haarlem) in 1967. In the same year, he went to Medical School at the University of Letden and graduated in 1974.

In 1975 and 1976 he worked as a resident in the department of obstetrics and Gynaecology in the Zeeweg Ziekenhuis, Velsen, and as a resident in the department of General Surgery in the Diaconessenhuls, Leiden. After a three month training course in tropical medicine in Amsterdam he went to kenya in 1976. There the worked as a general physician in the Provinclal General Hospital, Nyeri and as a medical officer in charge of the department of Surgery, Obstetrics and Gynaecology in the Kerugoya District Hospital. From 1980 to 1986 he was a resident in Surgery at the University Hospltal Maastricht (Head: Prof. Dr. J.M. Greep). In 1984, he was trained in reconstructive surgery in leprosy at ALERT Hospital, Addis Ababa, Ethiopia (Head: Dr. J. Andersen). In 1985 he was sent on a mission to the famine striken areas in Northern Ethiopla. At present, he is a resident in Plastic and Reconstructive Surgery at the University Hospital, Groningen (Head: Prof. Dr. A.J.C. Huffstadt). 